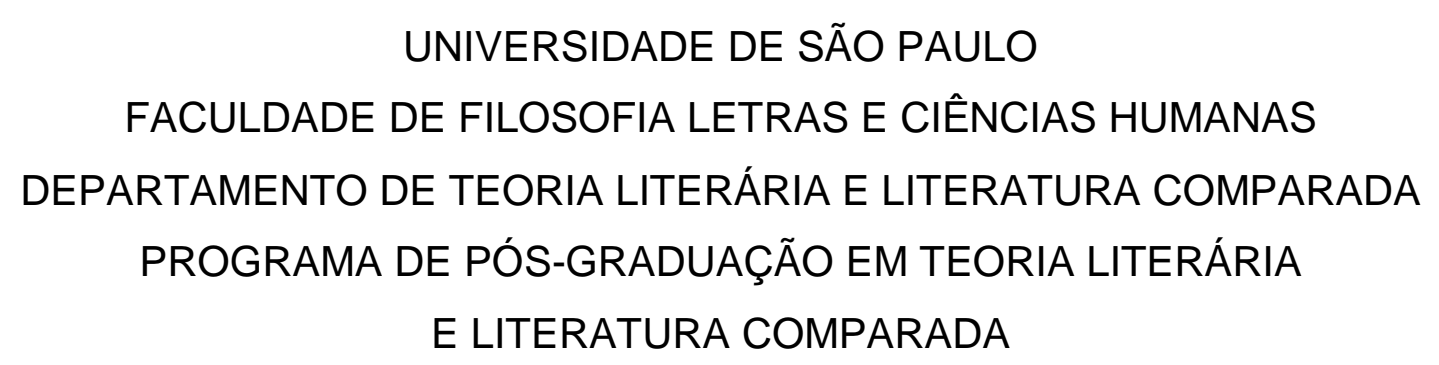

WALTER SCOTT E BALZAC: ROMANCISTAS DA HISTÓRIA

PAULA CALDAS FRATTINI

SÃO PAULO

2010 


\author{
UNIVERSIDADE DE SÃO PAULO \\ FACULDADE DE FILOSOFIA LETRAS E CIÊNCIAS HUMANAS \\ DEPARTAMENTO DE TEORIA LITERÁRIA E LITERATURA COMPARADA \\ PROGRAMA DE PÓS-GRADUAÇÃO EM TEORIA LITERÁRIA \\ E LITERATURA COMPARADA
}

\title{
WALTER SCOTT E BALZAC: ROMANCISTAS DA HISTÓRIA
}

\author{
PAULA CALDAS FRATTINI
}

\begin{abstract}
DISSERTAÇÃO APRESENTADA AO PROGRAMA DE PÓSGRADUAÇÃO EM TEORIA LITERÁRIA E LITERATURA COMPARADA DO DEPARTAMENTO DE TEORIA LITERÁRIA E LITERATURA COMPARADA DA FACULDADE DE FILOSOFIA, LETRAS E CIÊNCIAS HUMANAS DA UNIVERSIDADE DE SÃO PAULO COMO PARTE DOS REQUISITOS PARA A OBTENÇÃO DO TÍTULO DE MESTRE EM LETRAS.
\end{abstract}

ORIENTADORA: PROFA. DRA. SANDRA GUARDINI TEIXEIRA VASCONCELOS 
To my beloved husband Omar. 
AGRADECIMENTOS

Aos meus pais, Luiz Manoel e Silvia Helena e minhas irmãs, Fernanda e Luciana.

A Luís Eduardo Salvucci Rodrigues.

À Profa. Dra. Sandra Guardini Teixeira Vasconcelos.

À Coordenação de Aperfeiçoamento de Pessoal de Nível Superior - Capes, pela bolsa de Mestrado que me foi concedida. 


\section{RESUMO}

O nome de Walter Scott é repetidamente mencionado na obra de Balzac, sobretudo em seus textos críticos. Esta dissertação visa expor, para além da admiração patente do escritor, a penetração analítica de Balzac acerca do romance scottiano, o que the sugeriu um fundamento essencial para a formulação de sua Comédia Humana. Tendo como objeto de estudo a leitura dos textos críticos de Walter Scott e Balzac - seus prefácios principalmente -, procuramos demonstrar como o uso da História pelo romance tornou-se o elemento fundamental na aproximação entre os autores. Nossa intenção é deslindar, na fatura do romance, como se articula o entrecruzamento entre História e literatura.

Palavras-chave: Walter Scott, Balzac, História e Literatura, prefácio, romance século XIX. 


\section{ABSTRACT}

Walter Scott's name is repeatedly mentioned in the works of Balzac, mostly in his critical writings. This dissertation aims to show, beyond the writer's patent admiration, Balzac's penetrating criticism of the Scottian novel which disclosed to him a sound basis for the composition of his Comédie Humaine. Having Scott's and Balzac's critical writings as our object of study - mainly their prefaces - we intend to demonstrate how the incorporation of History by the novel became the essential element in this comparative study of the two writers. Our purpose is to elucidate how this intersection between history and literature is articulated in the narrative.

Keywords: Walter Scott, Balzac, Literature and History, prefaces, $19^{\text {th- }}$ century novel. 
ÍNDICE

Introdução.

.8

Capítulo I: O discurso prefacial de Walter Scott: um debate sobre o uso da história no romance. 20

Capítulo II: O discurso prefacial de Balzac: o modelo narrativo scottiano e a história do presente. .54

Considerações Finais. . .98

Bibliografia. .106 


\section{INTRODUÇÃO}

"Il est historien, voilà tout"1. Assim, Balzac define o autor da Comédia Humana em um dos seus prefácios. Para o nosso trabalho, que pretende realizar um estudo comparativo entre Walter Scott e Balzac, trata-se de uma definição que nos guia para o fulcro de nossa análise: o desejo de representação histórica em seus respectivos projetos literários. Deparamo-nos, portanto, com a questão de como História e ficção se fundem na forma do romance. Essa discussão fomentava os textos críticos de Walter Scott e Balzac, textos esses que, paralelamente, à obra ficcional, possuem extremo valor e são exemplo de uma "crítica viva", segundo definição de Antonio Candido.

A nosso ver, a importância dos textos críticos de Walter Scott e Balzac, para esse estudo comparativo, reside na discussão da representação histórica no processo de formação do romance histórico scottiano e do romance realista balzaquiano. Antonio Candido ressalta a pertinência do estudo da crítica realizada no período contemporâneo aos autores "porque ela é de certo modo a consciência da literatura, o registro ou reflexo das suas diretrizes e pontos de apoio." resultado desejado seria, então, a possibilidade de atingir um nível de compreensão mais apurado, afastando-nos, desse modo, de um ponto de vista unilateral, ou seja, uma interpretação pautada somente em considerações posteriores. Os textos críticos de Walter Scott e Balzac surpreendem pela acuidade e originalidade do teor analítico. Com efeito, apresentam, além de um debate interessante acerca de seu projeto literário, uma importância histórica em relação ao romance do século XIX.

A aproximação entre Walter Scott e Balzac não é acidental. Estamos diante da admiração explícita de Balzac por Walter Scott, documentada por meio de

\footnotetext{
${ }^{1}$ Balzac. Une Fille d'Ėve. Préface de la Première Édition. IN: Préfaces des Romans Français du XIX Siècle. Anthologie établie, présentée et annotée par Jacques Noiray. Paris: Le Livre De Poche, 2007, p.187.

${ }^{2}$ Antonio Candido. "Raízes da Crítica Romântica". IN: Formação da Literatura Brasileira. Belo Horizonte: Editora Itatiaia Limitada, 1981. Vol. II, p. 319.
} 
referências que sobejam em seus textos críticos. Porém, essas referências não devem ser consideradas casuais, ao contrário, é possível aferir, a partir desse todo referencial, uma filiação textual sustentada pelo entendimento de Balzac dos procedimentos de representação histórica presentes na narrativa scottiana. O que nos faculta fazer tal afirmação é o conteúdo dos textos críticos balzaquianos, nos quais aspectos formais e conceituais dos romances de Walter Scott são analisados. O escritor francês era um crítico detalhista, e sabia ilustrar eficazmente seus argumentos.

De modo geral, nos textos críticos de ambos os escritores estudados, notamos a articulação de um projeto literário. O que fundamenta o projeto de Walter Scott e Balzac é a formulação de um conceito que compreende a obra ficcional como um campo para o desenvolvimento da representação histórica de uma determinada realidade. Podemos traçar um paralelo da noção de obra literária, discutida pelos dois escritores, com a afirmação de Antonio Candido acerca da literatura:

A literatura é essencialmente uma reorganização do mundo em termo de arte; a tarefa do escritor de ficção é construir um sistema arbitrário de objetos, atos, ocorrências, sentimentos, representados ficcionalmente conforme um princípio de organização adequado à situação literária dada, que mantém a estrutura da obra. ${ }^{3}$

Sendo assim, é possível afirmar que o "princípio organizador" dos projetos literários de Walter Scott e de Balzac está relacionado a um "desejo de história". A representação histórica seria, portanto, o alicerce desse mundo ficcional.

Como já havíamos mencionado acima, a aproximação entre os escritores ocorre, primeiramente, no registro documental da presença do nome de Walter Scott nos textos de Balzac e, em segundo lugar, nos estudos historiográficos sobre a recepção do escritor escocês na França ${ }^{4}$ - que apontam Walter Scott como um

\footnotetext{
${ }^{3}$ Antonio Candido. Literatura e Sociedade. Rio de Janeiro: Ouro sobre Azul, 2006, p. 187.

${ }^{4}$ A esse respeito ver o estudo de Martyn Lyons, em que o autor discute o impacto da recepção de Walter Scott na França em termos sócio-históricos. Segundo o autor, Walter Scott foi responsável pela expansão da leitura de romances na sociedade francesa do século XIX, e pela diversificação do público leitor, na medida em que seus romances eram lidos por leitores de diferentes classes sociais: "Car Scott joue um rôle vital dans la formation d'un public littéraire de masse en France, en renversant les barrières de classe et d'éducation, et en aidant à faire du roman un objet de
} 
fenômeno cultural oitocentista. Contudo, as afinidades entre os escritores sobrepujam o que poderia ser apontado apenas como uma anedota nos estudos balzaquianos, pois, na verdade, são fruto de uma constelação sócio-histórica ${ }^{5}$ que Ihes era bastante peculiar.

Walter Scott e Balzac são escritores fundamentalmente marcados pelo despertar da consciência histórica no século XIX. A nova percepção histórica era decorrente das mudanças profundas provocadas pela Revolução Francesa e pelas guerras napoleônicas. O caráter universalista que vigorava no século das Luzes, juntamente com suas concepções abstratas sobre a natureza humana, é suplantado por uma particularização e maior objetividade. A redescoberta da história, vivenciada desde o final do século XVIII, redireciona a análise social estabelecendo novos paradigmas, os quais levavam em conta o homem concreto, real, isto é, sua vida finita e prosaica.

Para o historiador José Carlos Reis, nesse período da nova consciência histórica, a História adquire valor como ciência e se distingue, de forma definitiva, da Filosofia. A História é, a partir dessa redescoberta, capaz de compreender a vida humana da mesma forma que a Filosofia; entretanto, o método empregado pelos historiadores supunha a observação de dados concretos, e, sobretudo, a reflexão sobre os fatos "vividos".

consommation familiale quotidienne à travers tout le pays". IN: Lyons, Martin. "Walter Scott et les lecteurs du romantisme français". Le triomphe du Livre: une histoire sociologique de la lecture dans la France du XIXe siècle. Paris: Promodis, 1987, p. 139: "Pois Scott tem um papel vital na formação de um público literário de massa na França, ao derrubar as fronteiras de classe e educação, e ao ajudar a fazer do romance um objeto de consumo familiar cotidiano por todo o país." [Salvo as obras de autores de outros idiomas que já foram traduzidas e publicadas em português, as traduções dos autores citados nesse trabalho são de minha autoria.] Ver também o artigo "Sir Walter Scott and The French Press: Paris 1826" de Janette McLeman-Carnie, publicado no periódico International Review of Scottish Studies. Ontario: University of Guelph, volume 25, 2000, p.26-43. A revista disponibiliza o artigo no site http://www.irss.uoguelph.ca.

${ }^{5}$ Roberto Scharwz discute esse aspecto externo à correlação apenas estética entre dois escritores e argumenta de que maneira a organização formal da obra literária não ocorre per se, na medida em que se verifica um movimento dialético entre questões internas (forma) e externas (realidade) operando na composição da obra literária: "É seguro que as afinidades que apontamos não se devem à influência. $O$ seu eventual interesse aliás decorre daí, já que o molde comum que elas fazem supor tem de ser buscado noutro plano, externo às Letras, que só pode ser a constelação social própria ao Brasil do tempo." IN: Schwarz, Roberto. Duas Meninas. São Paulo: Companhia das Letras, 1997, p. 102. 
Esta é a revolução cultural historicista ${ }^{6}$ : uma revolução contra-revolucionária - a descoberta da história como fidelidade aos homens do passado. Ela não desvalorizava os séculos anteriores ao XVIII, como faziam os filósofos. Não opunha ao futuro de emancipação e luzes um passado de tirania e trevas, que seria preciso denunciar e destruir. Os historiadores queriam avaliar uma época segundo seus próprios critérios e valores. Para o historiador não é evidente que a Razão governa o mundo. Esta é uma convicção de filósofos. A aplicação da razão especulativa ao mundo dos homens tinha levado aos excessos da Revolução Francesa. Para eles, ao contrário, pensar a história filosoficamente, abstratamente, é que levava ao fanatismo, à tirania, às trevas. A teoria não é capaz de dirigir as coisas humanas. $\mathrm{A}$ vida humana é particular. A teoria trata de generalidades. A vida humana particular, singular, individual, é objeto da história e não da filosofia. A história é muito mais importante do que a teoria. As instituições humanas e o vivido humano não são o resultado do cálculo e da razão, mas do processo histórico, independente da vontade consciente dos indivíduos. ${ }^{7}$

Walter Scott representa essa nova visada histórica, em seus romances, antes de sua definitiva afirmação no solo francês durante o período da Restauração ${ }^{8}$. Waverley, seu primeiro romance, havia sido publicado em 1814. Nele, é narrado um momento específico da História escocesa: a insurreição jacobita de 1745 - The Forty-Five - que objetivava restaurar no poder a dinastia Stuart, devolvendo o trono a Charles Edward Stuart. Contudo, o aspecto preponderante da narrativa não é a crônica do fato, mas a apresentação, ao leitor, da vida dos homens de outrora inseridos em um momento histórico específico, ou seja, a fidelidade aos homens do passado apontada pelo historiador José Carlos Reis; o leitor é capaz, então, de apreender como a vida dos homens comuns era fustigada pela insurreição. Portanto, o que importava era o fato "vivido", o processo histórico.

\footnotetext{
${ }^{6}$ Embora a discussão do historiador José Carlos Reis gire em torno do conceito de historicismo termo esse que, como evidencia o autor, é complexo e dá margem a diferentes interpretações - e seus desdobramentos teóricos no campo da História, ressaltamos, nessa análise, a importância da discussão, na medida em que nos esclarece o contexto histórico-cultural do período em apreço.

${ }^{7}$ Reis, José Carlos. História \& Teoria. Historicismo, Modernidade, Temporalidade e Verdade. Rio de Janeiro: Editora FGV, 2006,p.209.

${ }^{8}$ A esse respeito, afirma Lukács: "La nouvelle conception historique des grands historiens de la Restauration apparaît même plus tard que ses œuvres et en est influencée dans la façon de poser certains problèmes." IN : Lukács, Georg. Le Roman Historique. Tradução de Robert Sailley. Paris: Petite Bibliothèque Payot, 2000, p. 30 : "A nova concepção histórica dos grandes historiadores da Restauração surge até mais tarde do que suas obras e é por elas influenciada na maneira de se questionar certos problemas."
} 
Além do próprio contexto histórico escocês ${ }^{9}$ que serviu como um impulso para a formação do romance scottiano, tornando-se seu objeto principal, julgamos outros dois fatos da biografia de Walter Scott como igualmente atuantes em seu projeto literário. O escritor escocês nasce em 1771 em Edimburgo, que, juntamente com Aberdeen e Glasgow, foi berço do lluminismo Escocês - movimento que possui um papel preponderante no desenvolvimento da concepção histórica incorporada pelo autor.

Em um ambiente intelectual vigoroso, em que figuravam nomes como David Hume, Adam Smith, Robert Burns, Adam Ferguson, entre outros, o lluminismo Escocês encetava um debate sobre a História enquanto produção de conhecimento. Hume definia a atmosfera da Escócia do século XVIII como "this is the historical Age, and this is the historical Nation". ${ }^{10}$

Devido aos problemas sociais e econômicos enfrentados pela Escócia no século XVIII e nos séculos precedentes, esses pensadores lançavam-se à investigação de suas causas e origens. Os fundamentos empregados pelo Iluminismo Escocês eram a análise filosófica da natureza humana e a análise empírica das sociedades. Para compreender e explicar a sociabilidade humana e seu desenvolvimento, os pensadores escoceses aplicavam uma análise histórica das instituições sociais, e para tanto era preciso "to remove "wonder" by discovering

\footnotetext{
${ }^{9}$ Durante muitos séculos a Escócia lutou pela sua legitimidade nacional, chegando a perdê-la no plano político em 1707, com o Tratado de União, que impingia ao país sua submissão política à Inglaterra. Além desse conflito na área externa, internamente o país era assolado por guerras civis em que interesses religiosos e regionais se opunham. As diferenças regionais eram determinadas geograficamente: a Escócia era dividida entre The Highlands (terras altas) e The Lowlands (terras baixas). A acentuada distinção geográfica era seguida por uma diferença econômica, política e cultural, herdada de longa data. Grosso modo, a população dos Highlands era mais pobre e guardava com mais rigor as tradições ancestrais, enquanto que a população dos Lowlands era mais rica e aberta à cultura inglesa. Segundo o historiador Michel Duchein, os Highlands eram "mal reliés au reste du pays, demeurent largement à l'écart. La langue gaélique y est vivace, le système des clans y subsiste, l'alphabétisation y est encore presque nulle, le niveau de vie primitif. Le problème des Highlands sera au cœur de l'histoire écossaise du XVIIle siècle." IN: Duchein, Michel. Histoire de L'Écosse. Paris: Fayard, 1998 : "eram mal conectadas ao resto do país, permanecendo largamente isoladas. A língua gaélica é, aí, viva, o sistema de clã subsiste, a alfabetização é quase inexistente, o nível de vida primitivo. O problema dos Highlands será o centro da história escocesa do século XVIII."

${ }^{10}$ Citado por Christopher J. Berry em "Science, Explanation and History". IN: Social Theory of the Scottish Enlightenment. Edinburgh: Edinburgh University Press, 1997, p.55: "Esta é a Era histórica, e esta é a Nação histórica."
} 
connecting principles". ${ }^{11}$ Todo esse processo analítico envolvia um princípio crucial para a narrativa scottiana: "a cautious observation of human life"12, nas palavras de Hume.

Devemos atentar à questão da "observação cautelosa da vida humana", pois esse mecanismo de análise pressupõe um olhar e uma construção narrativa específicos. Eis, então, um dado importante para a base de nosso argumento, que se refere à formulação de um projeto literário em que representação histórica e imaginação estão, em forma de programa, enlaçadas na fatura do romance.

Primeiramente, é preciso ressaltar a inovadora noção de "conexão" (connecting principles), citada acima, entre as mudanças ocorridas na vida humana ao longo do tempo. Para os historiadores do lluminismo Escocês, as diferentes sociedades não existiam isoladamente, o homem, sujeito histórico, era como era no presente, em conseqüência de suas conexões com o passado; assim, pela "obervação cautelosa" era possível constatar quais eram tais "conexões". Consequentemente, a vida humana passada é, na narrativa histórico-filosófica, analisada, de maneira racional, com o suceder do tempo.

Isso posto, concordamos com o crítico Peter D. Garside, quando este afirma que o lluminismo Escocês atuou como um catalisador no projeto literário de Walter Scott, na medida em que o autor escocês procura "reorganizar" as "conexões" entre passado e presente em seus romances, criando na narrativa um tempo histórico.

Entretanto, sua narrativa abre espaço para a imaginação, abandonando a "cautela" dos historiadores, o que nos permite, aqui, arrolar o segundo fato da biografia de Walter Scott que se relaciona a um incidente em sua vida ${ }^{13}$, como nos relata o próprio autor:

\footnotetext{
11 Berry, Christopher J. Op. Cit. p. 91: "remover o "deslumbramento", descobrindo princípios conectivos."

${ }^{12}$ Citado por Christopher J. Berry. Op. Cit. p.59.

${ }^{13}$ De fato, em 1773, Walter Scott foi acometido pela poliomielite, o que o obrigou a um longo tempo de repouso.
} 
When ${ }^{14}$ boyhood advancing into youth required more serious studies and graver cares, a long illness threw me back on the kingdom of fiction, as it were by a species of fatality. My indisposition arose, in part at least, from my having broken a blood-vessel; and motion and speech were for a long time pronounced positively dangerous. For several weeks I was confined strictly to my bed, during which time I was not allowed to speak above a whisper, to eat more than a spoonful or two of boiled rice, or to have more covering than one thin counterpane. When the reader is informed that I was at this time a growing youth, with the spirits, appetite, and impatience of fifteen, and suffered, of course, greatly under this severe regimen, which the repeated return of my disorder rendered indispensable, he will not be surprised that I was abandoned to my own discretion, so far as reading (my almost sole amusement) was concerned, and still less so, that I abused the indulgence which left my time so much at my own disposal. (...) At the same time I did not in all respects abuse the license permitted me. Familiar acquaintance with the specious miracles of fiction brought with it some degree of satiety, and I began by degrees to seek histories, memoirs, voyages and travels, and the like, events nearly as wonderful as those which were the work of imagination, with the additional advantage that they were at least in a great measure true. (...) It naturally occurred to me that the ancient traditions and high spirit of a people who, living in a civilized age and country, retained so strong a tincture of manners belonging to an early period of society, must afford a subject favourable for romance, it should not prove a curious tale marred in telling. ${ }^{15}$

Embora o trecho acima apresente um tom trivial, devemos ressaltar 0 aspecto ardiloso dessa característica. Todo esse prosaísmo articula-se à construção de uma narrativa que seria produto da "imaginação" mesclada à "observação" da vida humana em um tempo histórico, de modo que se diferencia da narrativa histórica propriamente dita.

Voltemos ao trecho. O que nos interessa é a evidência da fusão entre a representação histórica e a ficção na narrativa scottiana. A observação do historiador encontra-se com o mundo ficcional do romancista. Para Scott, tanto a realidade histórica quanto a imaginação oferecem o mesmo efeito ao leitor: o deleite. Podemos ir além e afirmar que a passagem que retrata sua estadia em Sandyknowe, nos Borders (fronteiras escocesas), simboliza o encontro entre a realidade histórica e a ficção. O contato com as tradições regionais, os registros da oralidade, a cultura dos clãs serão reorganizados na narrativa romanesca. Walter Scott, imbuído dos conceitos de história advindos de sua experiência universitária e do contato com o lluminismo Escocês, vai incorporar a observação analítica da natureza humana no reinado da ficção.

\footnotetext{
${ }^{14}$ Esclarecemos que algumas citações dos prefácios de Walter Scott são um pouco longas porque a maioria deles não é de fácil acesso. Igualmente extensas, são as citações dos romances dos autores, pois como não estamos discutindo um romance em particular, faz-se necessária uma referência mais completa do trecho citado.

${ }^{15}$ Scott, Walter. "General Preface". The Prefaces to the Waverley Novels by Sir Walter Scott edited by Mark A. Weinstein. Lincoln and London: University of Nebraska Press, 1978, p. 87-90.
} 
À vista de tais ideias, faz-se necessária uma consideração sobre a especificidade dessa construção narrativa em uma perspectiva contemporânea à composição dos romances. Walter Scott produzia um tipo de romance que apresentava detalhadamente os homens e os costumes de uma época distante, entretanto, a representação da vida humana era, pela primeira vez, fundamentada pela "observação" histórica. A representação histórica dos romances de Walter Scott abrangia questões sócio-culturais da população como um todo, por conseguinte, 0 processo histórico podia ser apreendido amplamente. Para Ann Rigney, as inovações temáticas e formais de Walter Scott devem ser consideradas no contexto "de um amplo projeto historiográfico que se move além da esfera da política e de operações militares para penetrar as esferas culturais e privadas, envolvendo a população em geral". 16

Balzac, por sua vez, é contemporâneo de um amplo movimento historicista nacional, que se empenhava em deslindar o processo histórico da nação. Assim como o movimento histórico-filosófico escocês, os historiadores franceses tinham como objeto de estudo o fato acontecido, o "revolu". ${ }^{17}$

O autor da Comédia Humana nasce em 1799 - ano em que Napoleão promove seu golpe de Estado - e inicia, efetivamente, sua carreira como escritor em 1829, quando publica Les Chouans, seu primeiro romance assinado como Honoré de Balzac. Esse romance segue a estrutura dos romances históricos de Walter Scott, pois trata de um acontecimento do passado histórico francês: uma tentativa isolada de insurreição contra os republicanos, em 1799, liderada por camponeses bretões. Em 1830, ano da Revolução de julho, Balzac abandona o tempo histórico do passado e se dedica à história do presente, ou seja, à história do período da Restauração que se iniciara em 1816.

\footnotetext{
16 "of a larger historiographical project to move beyond the sphere of politics and military operations into cultural and private spheres involving the population at large." IN: Rigney, Ann. Imperfect Histories: The Elusive Past and the Legacy of Romantic Historicism. Ithaca: Cornell University Press, 2001, p. 36.

${ }^{17}$ Petitier, Paule. "Balzac et la «Clio Classique »IN: Mozet, Nicole et Petitier, Paule (éds.). Balzac dans L'Histoire.Paris : SEDES, Collection du Bicentenaire, 2001, p.9.
} 
É, portanto, nesse quadro sócio-histórico de aceleradas mudanças que Balzac escreve seus romances, na tentativa de representar o presente em curso, criando a dimensão do tempo histórico de sua narrativa. A "observação", isto é, o objeto de estudo do autor da Comédia Humana é a sociedade da Restauração, e tal "recorte histórico" imprimirá à narrativa balzaquiana um movimento específico. É preciso, aqui, apontar algumas características importantes desse momento histórico da sociedade francesa.

A Restauração é eminentemente a sociedade do "parvenu"18; é o momento em que a acumulação do capital impulsionará a ascensão política e social, constituindo-se como o leitmotiv da sociedade burguesa do século XIX na França. A representação do processo histórico, para o "olhar de historiador" de Balzac, está circunscrita num período em que, seguindo a premissa de François Guizot ${ }^{19}$, a palavra de ordem é: "Enrichessez-vous!" ("Enriqueçam!"). Uma nova ordem social que imprime a diferença e faz a antiga ordem social desaparecer a olho nu. Para a épica balzaquiana o projeto histórico se restringe à "observação" desses novos tempos, cujo dinamismo inspira um novo registro temporal, como sugere claramente o trecho a seguir:

Chez nous, autrefois, le roman rencontrait aussi des élements fort simples et peu nombreux.Le seul roman possible dans le passé, Walter Scott l'a épuisé. C'est la lutte du serf ou de la bourgeoisie contre la noblesse, de la noblesse contre le clergé; de la noblesse et du clergé contre la royauté. Pour arriver à ses grands effets, il lui a fallu les rois, les reines et les grands effects, leurs points de cohérence avec les faibles. Autrefois tout était simplifié par les instituitions monarchiques; les caractères étaient tranchés: un bourgeois, marchand ou artisan, un noble entièrement libre, un paysan esclave, voilà l'ancienne socièté de l'Europe; (...) Aujourd'hui, l'Égalité produit en France des nuances infinies. Jadis, la caste donnait à chacun une physionomie qui dominait l'individu; aujourd'hui, l'individu ne tient sa physionomie que de lui-même. 20

\footnotetext{
${ }^{18}$ Sobre a sociedade francesa da Restauração, o historiador Eric Hobsbawm afirma: "Em uma palavra, a sociedade da França pós-revolucionária era burguesa em sua estrutura e em seus valores. Era a sociedade do parvenu (...)". IN: Hobsbawm, Eric. A Era das Revoluções 1789-1848. Rio de Janeiro: Paz e Terra, 1982, p.183.

${ }^{19}$ Francois Guizot foi um politico e historiador francês do século XIX.

${ }^{20}$ Balzac. Une Fille d'Ève. Préface de la Première Édition. IN: Préfaces des Romans Français du XIX Siècle. Anthologie établie, présentée et annotée par Jacques Noiray. Paris: Le Livre De Poche, 2007, p. $185-186$.
} 
O recorte temporal específico realizado pelo "olhar de historiador" do escritor francês é inovador, e essa inovação não ocorre apenas no campo específico da literatura, Balzac distingue-se também da prática histórica de seu tempo, como nos relata Paule Petitier:

\begin{abstract}
Le déplacement majeur qu'opère Balzac par rapport aux historiens de son temps concerne l'objet d'étude. Pour la plupart des historiens du premier XIXe siècle, la Revolution marque la limite du champ scientifique ; elle balise le domaine du révolu. Les œuvrages portant sur la période contemporaine relèvent de l'engagement politique ou de ses retombées, comme l'Histoire de dix ans de Louis Blanc ( 1840) ou Les Mémoires pour servir à l'histoire de mon temps de Guizot (1858-1867). Le présent joue un rôle essentiel dans la nouvelle histoire, mais à titre d'impulsion heuristique. Une expérience historique accélérée -sucession des régimes politiques, des guerres civiles et extérieures, changements sociaux - aurait armé les esprits du XIXe siècle pour comprendre les vicissitudes du passé, y retrouver des affrontements comparables d'intérêts et de visions du monde. Pour Balzac aussi la Révolution joue un rôle d'une coupure fondatrice instaurant le regard historien, parce qu'elle souligne jusqu'à le rendre aveuglant le passage au révolu et le moment où la persistence artificielle de celui-ci cède devant la pression du nouveau. Ce mouvement correspond à la tension dramatique de maint récit balzacien. ${ }^{21}$
\end{abstract}

Não seria o caso, então, de considerarmos uma ruptura em relação ao projeto literário de Walter Scott, quando Balzac se afasta do tempo histórico do passado? Se nosso estudo se concentrasse apenas em torno da questão de gênero narrativo, talvez não fosse possível realizar essa aproximação, uma vez que os romances balzaquianos tratam do presente histórico. Quando estabelecemos a correlação entre tempo histórico e este gênero narrativo - o romance histórico estamos pensando em concordância com Krzysztof Pomian, que considera uma articulação do romance histórico em torno de três exigências:

(..) celle de déplacer dans le temps vers le passé les instituitions, accessoires, croyances, mœurs, etc ; celle de mettre la psychologie des personnages en conformitée avec l'époque

\footnotetext{
${ }^{21}$ Petitier, Paule. Op. Cit. p.13: "O importante deslocamento que Balzac efetua em relação aos historiadores de seu tempo refere-se ao objeto de estudo. Para a maioria dos historiadores do século XIX, a Revolução marca o limite do campo científico; ela baliza o domínio do acabado. As obras que dizem respeito ao período contemporâneo revelam o engajamento político ou suas reincidências, como l'Histoire de dix ans de Louis Blanc (1840) ou Les Mémoires pour servir à l'histoire de mon temps de Guizot (1858-1867). O presente tem um papel essencial no romance histórico, mas a título de impulsão heurística. Uma experiência histórica acelerada - sucessão de regimes políticos, de guerras civis e externas, mudanças sociais - teria armado os espíritos do século XIX para compreender as vicissitudes do passado, e reencontrar, aí, afrontamentos comparáveis de interesse e visões de mundo. Para Balzac, a Revolução também tem um papel de ruptura fundadora, instaurando o olhar histórico, pois ela ressalta, até torná-lo cego, a passagem ao acabado e o momento em que a persistência artificial deste cede à pressão do novo. Esse movimento corresponde à tensão dramática de muitas narrativas balzaquianas."
} 
où ils sont censés avoir vécu; celles, plus générale, de rendre cohérent tous les déplacements temporels. ${ }^{22}$

Desse modo, quanto à exigência do deslocamento dos elementos da intriga em direção ao passado histórico, os romances balzaquianos não corresponderiam à estrutura do romance histórico de Walter Scott. Poderíamos, sob esse ponto de vista, realizar um estudo comparativo entre os romances de Scott e Les Chouans, em que o autor francês, efetivamente, realiza esse deslocamento. No entanto, a base de nosso argumento refere-se à relação entre o desejo de representação histórica - princípio organizador do projeto literário dos autores - e os dispositivos narrativos daí decorrentes. Pretendemos investigar como o romance dos autores fez uso da História, e acreditamos que as outras exigências propostas por Pomian, as quais indicam um princípio de coerência entre o plano narrativo e a realidade histórica, auxiliam-nos na nossa discussão. Mesmo sem o deslocamento em direção ao passado, os romances de Balzac incorporaram essa coerência, exigida pelos procedimentos de representação histórica - princípio definido pelo autor francês como "verdade literária"- compondo um projeto literário que pôde retratar a história do presente. Questionamos, então, quais foram os dispositivos narrativos que viabilizaram a representação histórica.

Com base em um corpus ${ }^{23}$ constituído pelos textos críticos dos autores e por excertos de alguns romances, elucidativos para nossa análise, pretendemos

\footnotetext{
22 "(...) aquela de deslocar no tempo, em direção ao passado, as instituições, os acessórios, as crenças, hábitos, etc; a de estabelecer uma conformidade entre a psicologia das personagens e a época que se supõe que estas tenham vivido; e aquela, mais geral, de tornar coerente todos os deslocamentos temporais efetuados." IN: Pomian, Krzysztof. "Histoire et Fiction”. Paris: Gallimard. Le Débat, número 54, 1989, p.114-137.
}

${ }^{23}$ O corpus ao qual nos referimos, no caso específico de Balzac, é uma seleção de prefácios, introduções e artigos escritos para revistas da época, compilados em duas obras, que serão utilizados ao longo desse estudo; são elas: Préfaces des Romans Français du XIX Siècle e Écrits Sur Le Roman. É indispensável incluir nesta análise, além dos prefácios, outros textos críticos de Balzac publicados em periódicos da época, pois esses textos fazem importantes referências ao romance scottiano. Em relação a Walter Scott, a análise gira em torno de seus prefácios, na medida em que centralizam a discussão sobre História e ficção, discussão que pretendemos investigar. Para tanto, lançamos mão da obra The Prefaces to the Waverley Novels by Sir Walter Scott. Juntamente com os textos críticos, serão analisados excertos dos romances Waverley e The Heart of Midlothian de Walter Scott e Illusions Perdues, Une Fille aux yeux d'or e L'Envers de L'Histoire Contemporaine de Balzac. Sobre a escolha dos romances, devemos assinalar que, em primeiro lugar, em razão da extensa produção romanesca dos dois autores seria impraticável nos determos em uma análise que englobasse o conjunto das obras. Em segundo lugar, selecionamos Waverley e Illusions Perdues, pois são romances referenciais no conjunto de suas obras, e os outros títulos mencionados articulam elementos -os quais serão debatidos no corpo da análise- que consideramos essenciais para a 
investigar quais dispositivos narrativos estariam em jogo na fatura do romance que toma forma a partir da dialética entre História e ficção. O cotejo entre o discurso crítico e a narrativa romanesca dos escritores permite-nos perquirir quais aspectos da representação histórica teriam sido assimilados na fatura romanesca.

Isso nos leva a um segundo aspecto de nossa análise - a discussão acerca do conceito de representação histórica no projeto literário dos autores. Para o leitor atual as figurações históricas na narrativa ficcional são corriqueiras, e as fronteiras entre o discurso histórico e o ficcional são evidentes. Porém, para Scott e Balzac tratava-se de uma discussão inaugural.

Isso posto, analisamos no Capítulo I os prefácios de Walter Scott. Nesses textos, discutimos a presença de um projeto literário que pretende tratar a História no campo da Literatura, e a maneira como o desejo de transmitir o conhecimento histórico foi articulado no plano narrativo.

No capítulo II, dedicamo-nos à análise dos textos críticos de Balzac, concentrando-nos nos aspectos relacionados à construção narrativa, a qual, conforme pretendemos demonstrar, toma corpo a partir de uma discussão sobre o uso da História pelo romance iniciada no projeto literário de Walter Scott.

Nas considerações finais, arrolamos brevemente os trabalhos dedicados ao estudo comparativo entre Walter Scott e Balzac e procuramos indicar como nossa abordagem sobre a aproximação entre os escritores se enquadra nesse panorama crítico. 


\section{Capítulo I}

\section{O discurso prefacial de Walter Scott: um debate sobre o uso da história}

no romance.

\section{A função dos prefácios de Walter Scott}

Walter Scott publica seu primeiro romance, Waverley (1814), inaugurando segundo um consenso da crítica moderna - um novo gênero narrativo ${ }^{24}$ : o romance histórico. Lukács, em sua obra O Romance Histórico, tem um papel preponderante na discussão, pois, segundo ele, o romance de Walter Scott teria surgido a partir de um movimento dialético entre uma base sócio-histórica e a forma artística. Da perspectiva lukacsiana, o romance scottiano seria "duplamente" histórico, uma vez que o objeto e a forma do romance estariam condicionados à História. ${ }^{25}$ Lukács está preocupado com o movimento entre o espírito histórico e a literatura. Ademais, a tese de Lukács redireciona os estudos sobre Walter Scott, quando define o escritor

\footnotetext{
${ }^{24}$ Alguns críticos tratam o romance histórico como gênero, outros como subgênero; para este estudo, o qual não se dedica exclusivamente à discussão do romance histórico, achamos por bem classificálo como um gênero narrativo.

${ }^{25}$ Essa ideia é desenvolvida por Claude-Edmonde Magny em seu prefácio para a edição francesa de O Romance Histórico: "Aussi, Le Roman historique est-il doublement intéressant pour Lukacs(sic): c'est que, prenant pour objet historique, il est lui même soumis à cette histoire; II baigne dans elle, par exemple par le choix même des ses sujets, ses vicissitudes en tant que genre, la variation de ses perspectives sur telle ou telle époque. Ainsi le pourrait-on dire doublement historique". IN: Lukács, Georg. Le Roman Historique. Tradução de Robert Sailley. Paris: Petite Bibliothèque Payot, 2000, p1: "Da mesma forma, O Romance Histórico é duplamente interessante para Lukács, visto que, considerado como objeto histórico, ele é igualmente submetido a essa história. Ele está imerso nela, por exemplo, pela própria escolha de seus temas, suas vicissitudes enquanto gênero, as variações de sua perspectiva sobre este ou aquele período. Assim, poderíamos dizer que ele é duplamente histórico."
} 
escocês como um "grande realista". O que permite ao filósofo húngaro atestar o caráter realista de Scott - o qual teria como ponto de apoio o romance realista do século XVIII ${ }^{26}$ - é sua noção dialética a respeito da história da literatura. Lukács a considera como um fluxo contínuo, historicamente fundamentado:

\begin{abstract}
Trata-se de um grande processo, um processo contínuo, de onde cada época tira o que the convém. Se vocês desejarem, eu procedo aqui uma inversão completa da ciência tradicional. A história da literatura comparada pensa tratar-se de uma influência: Götz Von Berlichingen influenciou o romance de Walter Scott, etc. Eu penso que na realidade a coisa dá-se de outra forma, como tentei mostrar em minha obra o Romance Histórico. A Revolução Francesa, as Guerras Napoleônicas, etc, o problema da historicidade é posto para a literatura que, como sabem, não existia ainda no séc. XVIII. Na medida em que Walter Scott foi atingido pessoalmente, ele encontrou, segundo a frase de Molière: "Je prends mon bien où je le trouve", um ponto de apoio em Götz Von Berlichingen, a despeito desta última obra ter surgido por outras razões. Isso tem para a ontologia da arte a conseqüência extremamente importante de que somente sobrevivem obras de arte que coincidem em um sentido largo e profundo com a evolução da humanidade e podem exercer em conseqüência efeito e interpretações as mais diversas. ${ }^{27}$
\end{abstract}

Com base nesse argumento, Lukács aproxima a obra de Walter Scott à de Balzac, pois o autor francês, de acordo com a leitura dialética lukacsiana, apresenta a ação recíproca entre o espírito histórico e a estrutura literária de sua obra. O ponto de apoio entre os escritores, que Lukács acertadamente aponta ${ }^{28}$, seria a nova

\footnotetext{
${ }^{26}$ Em seus prefácios, Walter Scott faz referência à excelência de Henry Fielding como romancista, considerando-o como o fundador do gênero: "Fielding had high notions of the dignity of an art which He may be considered as having found. He challenges a comparison between the Novel and the Epic. Smollett, Le Sage, and others, emancipating themselves from the strictness of the rules he has laid down, have written rather a history of the miscellaneous adventures which befall an individual in the course of life than a plot of a regular and connected epopeia, where every step brings us a point nearer to the final catastrophe." IN: The Prefaces to the Waverley Novels by Sir Walter Scott edited by Mark A. Weinstein. Lincoln and London: University of Nebraska Press, 1978, p. 45.
}

${ }^{27}$ Abendroth, Wolfgang et al. Entretiens avec Georg Lukács. Paris: Librarie François Maspero, 1969. Citado por Silva, Arlenice Almeida da. O Épico Moderno : O Romance Histórico de György Lukács. 1999. 220p. Tese de Doutorado - Faculdade de Filosofia, Letras e Ciências Humanas, Universidade de São Paulo, São Paulo, p.187.

${ }^{28}$ A esse respeito o crítico Harry E. Shaw afirma: "Georg Lukács is in my opinion essentially accurate in describing the history of the novel as a great stream from which tributaries branch off, only to rejoin and further enrich it in due course. Scott's works form such a tributary: he branches off from the eighteenth century novel, discovers in artistic terms the rich significance of History, and reunites with mainstream of the nineteenth-century fiction through his influences on Balzac, enriching it with new materials, insights and techniques." IN: Shaw, Harry E. "An Approach to the Historical Novel". IN: The Forms of Historical Fiction: Sir Walter Scott and his Successors. Ithaca, N.Y.: Cornell University Press, 1983, p.23: "Georg Lukács é em minha opinião essencialmente preciso quando descreve a história do romance como uma grande corrente, da qual tributários se subdividem, apenas para se reunirem e enriquecê-la, ainda mais, na ocasião oportuna. A obra de Scott se forma como tributária: ele se ramifica do romance do século XVIII, descobre em termos artísticos o importante significado da História, e se reúne com as principais obras de ficção do século XIX, através de sua influência sobre Balzac, enriquecendo-as com novos materiais, insights e técnicas." 
consciência histórica que surgia no século XIX; ambos os escritores estavam sintonizados com os problemas históricos da evolução humana. Para Lukács, Walter Scott, o "grande realista", funciona como um impulso no projeto literário de Balzac, ao revelar artisticamente a importância do processo histórico para o entendimento da vida humana:

Cette continuation du roman historique dans le sens d'une conception consciemment historique du présent est la grande réalisation de son éminent contemporain, Balzac. Balzac est l'écrivain qui développe de la manière la plus consciente la formidable impulsion que le roman a reçue de Scott, et de cette façon il crée le type nouveau, jusqu'alors inconnu du roman réaliste. ${ }^{29}$

A aproximação entre Walter Scott e Balzac realizada por Lukács não é desenvolvida além desse pequeno parágrafo. Entretanto, algumas questões importantes são mobilizadas nessa proposição tão concisa e merecem ser investigadas com mais atenção. Um primeiro aspecto diz respeito à insistência no termo "consciente". A reiteração do termo refere-se a duas categorias distintas: um entendimento de caráter epistemológico acerca da História - "concepção conscientemente histórica do presente" - e uma visão crítica sobre a apropriação de um modelo narrativo - "o escritor desenvolve da maneira mais consciente o impulso formidável que o romance recebeu de Scott". Outra questão significativa concerne à afirmação de que o modelo narrativo scottiano serviria como base para a formação do romance realista balzaquiano. Sendo assim, interessa-nos analisar essas questões levando em consideração o entrecruzamento entre história e ficção na fatura do romance e a discussão sobre representação histórica, aspecto que não é explorado pelo estudo de Lukács. Aqui, uma importante observação deve ser feita, a qual não é discordante da tese lukacsiana, e se refere à historicidade da construção da narrativa romanesca scottiana. O romance histórico de Walter Scott surge em um momento de debate sobre a escrita da história. De forma que, em seu ambiente sócio-cultural, Walter Scott vai haver-se com as questões do lluminismo Escocês e do antiquarianismo, como discutiremos em seguida.

\footnotetext{
${ }^{29}$ Lukács, Georg. Op.Cit. p88. Itálico nosso: "Essa continuação do romance histórico no sentido de uma concepção conscientemente histórica do presente é a grande realização de seu eminente contemporâneo Balzac. Balzac é o autor que desenvolve da maneira mais consciente a formidável impulsão que o romance recebeu de Scott, criando, dessa forma, o tipo até então desconhecido do romance realista."
} 
À vista dessas considerações, procuramos demonstrar que paralelamente à formação do romance - como aponta a tese lukcasiana - a articulação entre História e romance também está presente no pensamento crítico de Walter Scott, o que nos permite discutir qual seria a compreensão do autor sobre representação histórica e o modo como tal conceito foi incorporado na narrativa. Seguindo esse fio interpretativo, acreditamos ser possível esclarecer alguns aspectos do percurso da apropriação do modelo narrativo scottiano por Balzac.

Os prefácios de Walter Scott afiguram-se como um manancial importante para a discussão. Poucos trabalhos analíticos, entre a fortuna crítica do escritor, dedicaram-se somente a esses textos. Muitas vezes, eles são utilizados isoladamente como aporte interpretativo dos romances analisados e, de fato, esta não deixa de ser uma instância significativa. No entanto, o que mais tem a nos dizer o discurso prefacial scottiano? Para o início de nossa discussão sobre o que estaria articulado nos prefácios, achamos relevante destacar um dos poucos estudos dedicados aos prefácios de Walter Scott, a obra Prefacing the Waverley Prefaces de Patricia S. Gaston.

Um dos pontos polemizados por Gaston reside justamente na escassez de estudos relevantes sobre os prefácios e nas críticas negativas que desconsideram completamente a importância desses textos no estudo da obra de Walter Scott, como ela nos esclarece nesta passagem:

Critics from Carlyle onward have suggested that the Waverley novels could only benefit from the removal of these "forwarding" pages, their shared opinion based upon diverse reasons which include the idea that most of the novels are too long already (and the typical Waverley novel is long); that the prefaces are poorly written, have no actual purpose, demonstrate no artistic design; ${ }^{30}$

Primeiramente, Patricia S. Gaston ressalta a importância de Lukács na fortuna crítica de Walter Scott. Segundo ela, críticos importantes da obra do autor, como David Brown, Avrom Fleishman e Harry E. Shaw, os quais são tributários de

\footnotetext{
${ }^{30}$ Gaston, Patricia S. Prefacing the Waverley Prefaces. New York: Peter Lang Publishing, 1991, p.25. Itálico da autora: "Críticos a partir de Carlyle em diante têm sugerido que os romances de Waverley poderiam se beneficiar com a remoção destas páginas "iniciais", a opinião que compartilham é baseada em diversas razões, as quais incluem a ideia de que a maioria dos romances já são muito longos (e o romance típico do Waverley Novels é longo); que os prefácios são mal escritos, não têm nenhum propósito e não demonstram nenhum projeto artístico".
} 
Lukács, estão sempre, sob certos aspectos, em constante debate com a tese lukcsiana. Todavia, prossegue ela, o teórico não menciona em sua análise os prefácios de Walter Scott, lacuna que considera problemática no estudo lukcasiano:

\begin{abstract}
Lukács, for one, makes no mention of the prefaces, thus seeming to adopt the traditional critical stance that the actual Waverley novel begins after the prefaces end and that the novel would be a better one for the excision of the prefatory material. Lukács overlooks the element of authorial and textual play at work in the novels' opening pages; more important to his own reading of Scott, Lukács also overlooks the essential despair sometimes expressed by the Waverley personae over the historical process, which they see not as dialectic, but as apocalypse. $^{31}$
\end{abstract}

A nosso ver, a afirmação de que o estudo de Lukács seria consoante com a leitura que desprestigia os prefácios, relegando-os a um segundo plano na interpretação da formação de seu romance, é discutível. Os pressupostos analisados em $O$ Romance Histórico estão mais direcionados à elaboração teórica acerca do caráter mediatizado da forma romance, a qual incorpora materialmente a "verdade" de seu tempo. ${ }^{32}$ Lukács discute, como afirma Harry E. Shaw, de que maneira o romance histórico scottiano é uma forma de conhecimento da realidade. Ademais, a obra não se presta, tão-somente, à análise da obra de Walter Scott.

Mesmo não sendo nosso intuito uma análise de $O$ Romance Histórico, parece-nos necessário pontuar alguns aspectos que julgamos problemáticos nessa interpretação dos prefácios em relação à tese lukcasiana. Primeiramente, o pensador húngaro fundamenta sua tese em torno da historicidade da forma artística e sua investigação procura demonstrar como a gênese, o desenvolvimento e o declínio do romance histórico são o resultado de uma base sócio-histórica específica. Dessa maneira, Lukács entrevê na forma do romance scottiano um reflexo artístico de um momento histórico específico. Esse período de formação do

${ }^{31}$ Gaston, Patricia S. Op. Cit., p. 4. Itálico da autora: "Lukács, por exemplo, não menciona os
prefácios, parecendo adotar, dessa maneira, uma instância crítica tradicional para a qual o genuíno
romance da série do Waverley Novels inicia-se após o término dos prefácios e seria um romance
melhor com a exclusão do material prefacial. Lukács não considera o jogo autoral e o textual em
ação nas páginas iniciais do romance. Mais importante para sua própria leitura de Scott, Lukács
desconsidera, igualmente, a essencial desesperança, às vezes expressa pelas personas dos
Waverley Novels, a respeito do processo histórico, o qual elas veem não como dialético, mas como
apocalipse". 32 "O Romance Histórico contém verdade, salienta Lukács inúmeras vezes, pois visa 'figurar artisticamente a gênese concreta de seu tempo". IN: Silva, Arlenice Almeida da. Op.Cit.p.178. 
romance histórico é considerado pelo crítico como a forma clássica do gênero. A averiguação do movimento dialético prossegue nos estudos de outras obras de épocas e tradições literárias diferentes. Portanto, a tese lukcasiana é um exame teórico a respeito da historicidade da forma e não uma análise da obra scottiana. $O$ julgamento de Gaston leva-nos a apontar outro aspecto questionável de sua análise, o qual se refere ao entendimento do discurso prefacial scottiano como parte imprescindível da narrativa romanesca propriamente dita.

No seu estudo sobre o discurso prefacial de Walter Scott, Patricia S. Gaston fundamenta seu argumento em torno da noção de "textualidade". No entender da crítica, a narrativa histórica - esteja ela inserida no campo da historiografia ou da ficção - deve ser tratada como um texto "fabricado", um artefato. Dessa forma, os prefácios seriam cruciais na interpretação da obra scottiana, na medida em que estabelecem um contrato entre narrador e leitor. Esse "contrato" desarticularia o caráter realista da obra, pois ele torna a "fabricação" da narrativa romanesca explícita, rompendo qualquer ligação com o referencial histórico:

\begin{abstract}
A prime effect of a text's self-consciousness is to invite its readers to encounter it as a palpable object and not as a mirror held up to reflect a given epoch. As I have suggested, Scott's historical novels, seemingly grounded in exterior events, seemingly committed to a representation of a life as "really" lived in the past, put forward supplementary practices which obtrude on the technical accuracy of the representation, as they breach the boundaries set by the conventions of realism. Moreover, the Waverley novels do this with self-conscious relish and, in so doing, seem to ask for a different contract between text and reader than that entered into by those critics who, following Lukács, have assumed Scott to be more or less objective historical novelist. ${ }^{33}$
\end{abstract}

A desarticulação da objetividade histórica estaria relacionada, segundo Patricia S. Gaston, a um uso complexo da autoridade narrativa, dispersa em diferentes narradores. De fato, como indica a crítica, Walter Scott somente assume a autoria de seus romances em 1827, quando decide publicar o conjunto de suas

${ }^{33}$ Gaston, Patricia S.Op. Cit. p. 34: "O principal efeito da autoconsciência de um texto é convidar seus leitores a encará-lo como um objeto palpável e não como um espelho exposto para refletir uma determinada época. Como sugeri, os romances históricos de Scott, aparentemente fundamentados em eventos exteriores, aparentemente comprometidos com uma representação da vida como "realmente" fora vivida no passado, apresentam mecanismos suplementares os quais dificultam a precisão técnica da representação, uma vez que eles rompem os limites estabelecidos pelas convenções do realismo. Ademais, os romances da série dos Waverley Novels o fazem com um prazer autoconsciente e, ao realizarem isto, parecem solicitar um contrato diferente, entre o texto e o leitor, do que aquele admitido por críticos, os quais, seguindo Lukács, consideram que Scott é um romancista histórico mais ou menos objetivo." 
obras em uma edição intitulada Magnum Opus. ${ }^{34}$ As obras anteriores a essa data eram publicadas anonimamente e o autor assinava seus prefácios sob o nome de diferentes personagens. Há, portanto, dois grupamentos de prefácios: os prefácios originais, assinados pelas diferentes personagens - que a crítica designa como personae - e os prefácios posteriores, que substituíram os originais, assinados como Walter Scott. A diferença entre esses dois grupamentos, como define Patricia S. Gaston, diz respeito à intenção. O tom do primeiro grupamento é mais irônico enquanto o segundo é mais didático, preocupando-se mais em expor o material histórico do romance que introduzem.

Chegamos, então, à questão central do argumento apresentado pela crítica: a narrativa histórica é um artefato e o passado somente pode ser retratado a partir de diferentes pontos de vista, e é tarefa das personae introduzir os limites e o sentimento de impossibilidade de reproduzir o passado histórico objetivamente, senão de forma fragmentada e imaginada.

The dilemma is this: if history is the attempt to recreate the past in language, and if history
must depend upon human evidence to do this, then history is confronted with a seemingly
insurmountable problem in that each human witness will report according to individual
perception, no version will be identical with any other version nor will any version be a
privileged text. What the personae most frequently do in the face of this dilemma is to include
as many versions as possible of accounts of any given event; but what this strategy amounts

${ }^{34}$ A decisão pela publicação desta coleção foi motivada por motivos financeiros. Walter Scott experimentava um período de sérias dificuldades financeiras e a ideia de publicar uma edição com todas as suas obras- as quais, até aquela data, eram anônimas - sob sua assinatura, avultava suas expectativas de escapar à falência. Curiosamente, Balzac foi, da mesma maneira, um autor que lutou por toda sua vida contra o fantasma da falência, encontrando na literatura um meio de sobrevivência. Esse motivo da publicação da Magnum Opus é corroborado pelo próprio Walter Scott: "In the pen of this nameless romancer I seemed to possess something like the secret fountain of coined gold and pearls vouchsafed to the traveler of the Eastern tale; and no doubt believed that I might venture, without silly imprudence, to extend my personal expenditure considerably beyond what I should have thought of had my means been limited to the competence which I derived from inheritance, with the moderate income of a professional situation. I bought, and built, and planted, and was considered by myself, as by the rest of the world, in the safe possession of an easy fortune. My riches, however, like the other riches of this world, were liable to accidents, under which they were ultimately destined to make unto themselves wings and fly away. The year of 1825 , so disastrous to many branches of industry and commerce, did not spare the market of literature. (...) Among other resources which occurred was the project of that complete and corrected edition of his novels and romances (whose real parentage had of necessity been disclosed at the moment of commercial convulsions alluded)". Scott, Walter. "Chronicles of the Canongate". IN: The Prefaces to the Waverley Novels by Sir Walter Scott edited by Mark A. Weinstein. Lincoln and London: University of Nebraska Press, 1978, p.228229. 
to within the text is an undermining of traditional narrative authority, because all of the versions are flawed and because together, they still cannot recreate past event. ${ }^{35}$

O estudo empreendido por Patricia S. Gaston é profícuo, haja vista que realiza um levantamento do discurso prefacial de Walter Scott, produzindo um histórico detalhado das personae. Além disso, ela assinala a relevância dos prefácios nos estudos scottianos, destacando a riqueza da reflexão crítica ali contida e, sobretudo, a existência de um pensamento sobre a construção narrativa. Contudo, seu estudo focaliza somente a sobreposição da leitura do discurso prefacial à narrativa, evidenciando um "jogo" textual que nega a possibilidade de um conhecimento histórico ou da realidade.

Dessa maneira, pensar o discurso prefacial de Walter Scott apenas do ponto de vista da "textualidade" nos conduz a alguns questionamentos. Os prefácios estão, obrigatoriamente, vinculados à narrativa? $O$ que eles introduzem? A impossibilidade da reprodução objetiva do passado? E o que dizer dos prefácios que levam a assinatura de Walter Scott, para a coleção Magnum Opus; o que introduziriam, visto que o jogo com a autoria narrativa não se faz mais presente?

Entendemos que não é possível realizar uma leitura que leve em consideração apenas a ideia de desarticulação do real, pois, ao se aproximar em demasia da função textual das personae, a voz crítica a respeito do desejo de construção de um projeto literário ausenta-se. Ao se distanciar da voz crítica para se concentrar tão-somente na voz fictícia das personae, a análise impossibilita o entendimento dialético - de que fala Lukács - da narrativa scottiana. Se o entendimento das personae em relação ao processo histórico, segundo a crítica, não é dialético, mas apocalíptico, ou seja, há uma impossibilidade de se representar objetivamente a realidade histórica, como explicaríamos a relação dos prefácios com uma estrutura narrativa que prima pela tensão dramática entre forças opostas:

${ }^{35}$ Gaston, Patricia S. Op. Cit. p. 76: "Esse é o dilema: se a História é uma tentativa de recriar o passado pela linguagem, e se a História precisa depender de evidência humana para fazê-lo, então, ela será confrontada com um suposto problema aparentemente insuperável, pois cada testemunha humana realizará um relato de acordo com sua percepção individual, nenhuma versão será idêntica a qualquer outra, muito menos será alguma versão um texto privilegiado. $O$ que as personae mais frequentemente fazem diante desse dilema é incluir tantas versões quanto possível de relatos de determinados acontecimentos. Entretanto, o que essa estratégia significa no texto é um enfraquecimento da tradicional autoridade narrativa, pois todas as versões são falhas, e porque juntas, elas ainda não são capazes de recriar o evento passado". 
tradições antigas opondo-se às inovações incorporadas de uma sociedade civil mais organizada, as "terras altas" em contraste com as "terras baixas", a cultura escocesa em oposição à cultura inglesa, enfim, as diferentes contradições presentes no processo histórico? Entendemos que o projeto literário de Walter Scott, como é expresso em seus prefácios, possui uma posição nitidamente contrária à interpretação apresentada pela crítica. O que fica evidente, ao longo dos prefácios, é uma reflexão consciente sobre o uso da história pela literatura. No discurso prefacial, o autor irá postular a possibilidade do conhecimento de um tempo vivido real no campo da ficção.

A asserção de Genette, a respeito da função principal do discurso prefacial, corrobora essa interpretação, pois, de acordo com o crítico francês, o prefácio tem como função comunicar uma intenção ou interpretação do autor e/ou editor ${ }^{36}$. Isso nos permite inferir que, de fato, no caso dos prefácios de Walter Scott, existe a intenção de um projeto literário que pretende fundir história e ficção. O que percebemos é muito mais uma discussão sobre como elaborar tal entrecruzamento, ou seja, como construir uma narrativa em que elementos (realidade histórica e imaginação) até então considerados opostos serão seu pilar de sustentação.

Para a historiadora Sandra Jatahy Pesavento, a aproximação entre história e literatura é possível, pois são narrativas que têm o real como referente, entretanto, cada qual guarda sua especificidade. No campo da historiografia, o referencial histórico é condição sine qua non, enquanto que no campo da literatura a questão é mais complexa, pois o mundo ficcional lida abertamente com a imaginação. Podese incorrer no erro e entender o imaginário como uma categoria sem nenhum vínculo com a realidade. Segundo essa ótica, trata-se ou de real ou de ficção. No entanto, o imaginário mobiliza tanto o conhecimento racional quanto o sensível, constituindo, na definição da historiadora, um "sistema de representações sobre o mundo que se coloca no lugar da realidade, sem com ele se confundir, mas tendo nela seu referente" ${ }^{37}$. Se para a historiografia o imaginário se coloca como um

\footnotetext{
${ }^{36}$ Ver Genette, Gérard. Seuils. Paris: Éditions du Seuil, 1987, p.15.

${ }^{37}$ Pesavento, Sandra Jatahy « História \& literatura: uma velha-nova história », Nuevo Mundo Mundos Nuevos [En línea], Debates, 2006, Puesto en línea el 28 janvier 2006. URL: http:// nuevomundo.revues.org/index1560.html p.2.
} 
problema, a narrativa romanesca que deseja representar a realidade histórica faz o caminho inverso em relação ao referencial histórico que se torna, para a literatura, uma discussão controversa.

Como veremos em seguida, Walter Scott, em seus prefácios, já se lançava em uma discussão sobre a possibilidade de representação do passado no campo ficcional através da dialética da realidade histórica e da ficção. A questão central dos prefácios, então, refere-se aos procedimentos que um romancista deverá mobilizar para atingir esse objetivo.

2- O diálogo entre Clío e Calíope.

Analisaremos, primeiramente, os prefácios originais de Walter Scott. Porém, antes de iniciarmos a análise, é preciso salientar um aspecto essencial sobre os prefácios scottianos que diz respeito ao seu caráter ficcional. Os prefácios originais de Scott engendram um sistema autoral fictício composto, principalmente, por $^{38}$ :

- Sir Laurence Templeton, autor da epístola dedicatória de Ivanhoe.

- Captain Cuthbert Clutterbuck, autor da epístola introdutória de The Monastery e The Fortunes of Nigel.

- Dr. Jonas Dryasdust, autor da carta prefatória de Peveril of the Peak.

- Jedediah Cleishbotham, autor do prefácio de Old Mortality.

- Voz narrativa na primeira pessoa anônima, autora dos prefácios e posfácio de Waverley, Review of Tales of My Landlord, Introduction to Old Mortality e Introduction to The Bride of Lammermoor.

\footnotetext{
${ }^{38}$ Ver o capítulo "Prefacing the Waverley Prefaces: Players, Sites, and Identities" do livro Prefacing the Waverley Prefaces, onde encontramos uma lista dos romances da série dos Waverley Novels, as datas de publicação e as diferentes autorias prefaciais, anteriores à publicação da edição Magnum Opus. IN: Gaston, Patricia S. Op. Cit., p.19-42.
} 
- The Author of Waverley - que não deve ser confundido com a voz narrativa mencionada acima - presente nos prefácios de Peveril of the Peak e The Fortunes of Nigel. ${ }^{39}$

Embora essa rede autoral fictícia pareça um tanto complexa, a intenção dos prefácios é sempre muito clara: ao leitor é apresentado um novo tipo de narrativa romanesca que incorpora na sua urdidura o saber histórico. A complexidade da rede se desfaz quando percebemos uma proposital dualidade de posicionamentos em relação ao entendimento sobre a construção romanesca e a histórica. De um lado, estão as personae representantes do discurso historiográfico e do antiquarianismo, e de outro, os defensores da nova narrativa romanesca que faz uso da História. Essa dualidade objetiva demonstrar ao leitor a verdadeira natureza do texto ficcional que não trata cientificamente da história e muito menos é desprovido de um referencial histórico. Os romances pretendem "representar" o passado histórico da Escócia, compreendido na sua dimensão coletiva e individual. Nesse sentido, a visão do processo histórico apresentada pelas personae é estruturada dialeticamente em torno de uma discussão que acabará por explicar o sentido da "representação histórica" no romance. O conflito entre os diferentes posicionamentos não é apocalíptico e sim dialético.

O embate entre as personae apresenta uma historicidade subjacente, pois a formação do romance scottiano coincide com uma discussão em voga àquela época acerca da escrita da História. A prática historiográfica toma corpo como ciência, efetivamente, no século XIX e passa a questionar as convenções do discurso historiográfico. Entretanto, desde o século XVII a História, como afirma o filósofo Krzysztof Pomian, "atribui-se o status de uma ciência, de um saber fundamentado no conhecimento do passado por intermédio de fontes e que se beneficia, por essa razão, de uma razoável veracidade". ${ }^{0}$ Adicionaríamos à proposição, no contexto

\footnotetext{
${ }^{39}$ Nos prefácios originais de Walter Scott podemos encontrar ainda outras personae, porém limitamonos a essas personae listadas, devido à impossibilidade de cobrir a extensa obra de Walter Scott e à importância desses prefácios para a discussão do nosso trabalho.

40 “À partir du XVIle siècle, l'histoire savante s'attribuie le statu d'une science, d'un savoir fondé sur la connaissance du passé par l'intermédiaire des sources et qui benéficie à ce titre d'une raisonable
} 
específico da Escócia ${ }^{41}$, as discussões metodológicas sobre o conhecimento do passado. O conceito de História parece fazer parte da vida política e cultural escocesa, já que desde o século XIII o país experimentava um sentido emergente de nacionalidade. Sempre imersa em disputas políticas com a Inglaterra no tocante à sua soberania, a Escócia foi berço de muitos pensadores que se dedicaram ao estudo da identidade nacional escocesa, produzindo extensa documentação sobre o passado escocês. $O$ antiquarianismo é oriundo dessa tradição historiográfica e fundamenta seu conhecimento do passado na pesquisa de lugares e monumentos e na compilação de documentos antigos, como, por exemplo, manuscritos e objetos. $\mathrm{O}$ antiquarianismo perde força somente no século XVIII com o florescimento do lluminismo Escocês e passa a ser tomado como um tipo de conhecimento histórico "menos sério", sendo associado a erros e concepções equivocadas, por não desenvolver um entendimento crítico do processo histórico, limitando-se ao registro de evidências materiais do passado. Como define Stephen Bann, os antiquarianistas tornam-se as "ovelhas negras" entre os eruditos da história. ${ }^{42}$

Ora, Walter Scott enquanto escritor não é refratário à discussão historiográfica e, fato curioso, posiciona-se entre o lluminismo Escocês e o antiquarianismo. Um pouco como Molière, como fora citado por Lukács, o autor escocês "retira o que the serve, onde o encontra". E o que the serve nos dois modelos de conhecimento sobre o passado? Em primeiro lugar, é evidente que Walter Scott, seguindo os pressupostos do lluminismo Escocês, entende as conexões entre os acontecimentos pretéritos e o estado atual do presente, evidenciando, dessa maneira, o sentido de um processo histórico, que somente pode ser compreendido através da observação dos conflitos que ocorreram no passado. A noção de processo histórico fica clara neste trecho do posfácio, da primeira publicação de Waverley, em que o autor aponta a diferença entre os

certitude." IN: Pomian, Krzysztof. "Histoire et Fiction". Paris: Gallimard. Le Débat, número 54, 1989, p.114-137.

${ }^{41}$ Sobre a historiografia escocesa ver: Woolf, Daniel R. A Global Encyclopedia of Historical Writing: K-Z. New York: Garland Pub., 1998, 2v, p.819-820.

${ }^{42}$ A esse respeito ver o capítulo "Clio in part: on antiquarianism and the historical fragment". IN: Bann, Stephen. The Inventions of History: Essays on the Representation of the Past. Manchester and New York: Manchester University Press, 1990, p.100-122. 
costumes de outrora e os atuais, em decorrência das tensões sócio-políticas que abalaram o país:

There is no European nation which, within the course of a half century or little more, has undergone so complete a change as this kingdom of Scotland. The effects of the insurrection of 1745, - the destruction of the patriarchal power of the Highland chiefs, - the abolition of the heritable jurisdiction of the Lowland nobility and barons, - the total eradication of the Jacobite party, which, averse to intermingle with the English, or adopt their customs, long continued to pride themselves upon maintaining ancient Scottish manners and customs, - commenced this innovation. The gradual influx of wealth and extension of commerce have since united to render the present people of Scotland a class of beings as different from their grandfathers as the existing English are from those of Queen Elizabeth's time. ${ }^{43}$

Antes de analisarmos o trecho em questão, é importante salientar a escolha do posfácio para o desenvolvimento de sua tese. O autor lhe atribui o seguinte título: "Um Posfácio que Deveria Ter Sido um Prefácio". Em seguida, temos a explicação dessa mudança:

This should have been a prefatory chapter, but for two reasons: First, that most novel readers, as my own conscience reminds me, are apt to be guilty of the sin of omission respecting that same matter of prefaces; Secondly, that is general custom with that class of students to begin with the last chapter of a work; so that, after all, these remarks, being introduced last in order, have still the best chance to be read in their proper place. ${ }^{44}$

O autor faz tanta questão que seu leitor leia os prefácios e compreenda a natureza da narrativa prestes a se iniciar que, se este ignorar a leitura prefacial, sua única e última solução é o posfácio. Fica evidente, portanto, uma preocupação ou a intenção do discurso prefacial - digamos um tanto incomum para o texto literário em compartilhar o conhecimento histórico com o leitor.

Mas, voltemos ao trecho em que Walter Scott analisa o processo histórico. Percebemos que o texto ressalta a necessidade de se olhar para o passado, de observá-lo com cautela para que ele seja compreendido, pois as mudanças não são tão evidentes e gradativas. Sendo assim, somente o olhar atento é capaz de descortinar o conhecimento de nossa história:

\footnotetext{
${ }^{43}$ Scott, Walter. "Waverley (1814). A Postscript Which Should Have Been a Preface". The Prefaces to the Waverley Novels by Sir Walter Scott edited by Mark A. Weinstein. Lincoln and London: University of Nebraska Press, 1978, p. 3.

${ }^{44}$ Idem, Ibidem, p. 3.
} 
But the change, though steadily and rapidly progressive, has, nevertheless, been gradual; and like those who drift down the stream of a deep and smooth river, we are not aware of the progress we have made until we fix our eye on the now distant point from which we have been drifted. ${ }^{45}$

Entretanto, Walter Scott não quer apenas apresentar fatos, construir uma narrativa crítica sobre o passado, não quer que seu leitor apenas entenda, quer que ele seja espectador. Um dos objetivos do projeto literário de Walter Scott é justamente conduzir o olhar do leitor na observação do passado. Para tanto, sua narrativa reconstrói o passado histórico com o auxílio do imaginário:

It was my accidental lot, though not born a Highlander (which may be an apology for much bad Gaelic), to reside during my childhood and youth among persons of the above description; and now, for the purpose of preserving some idea of the ancient manners of which I have witnessed the almost total extinction, I have embodied in imaginary scenes, and ascribed to fictitious characters, a part of the incidents which I then received from those who were actors in them. ${ }^{46}$

Walter Scott, no trecho acima, deixa claro que o referencial de sua narrativa é o passado histórico, quando afirma que seu objetivo é representar o que já se extinguiu, propiciando ao leitor "uma ideia dos hábitos antigos". No entanto, para alcançar tal intento, precisa suplantar o vazio do que já se foi com "cenas imaginárias", e investir as personagens fictícias com uma parcela de realidade, a qual the é transmitida pelo testemunho daqueles que vivenciaram os eventos transcorridos. O autor escocês sempre faz questão de evidenciar a natureza ficcional de sua narrativa, contudo, suas intenções fazem eco ao projeto de uma narrativa histórica, pois, às convenções romanescas alia procedimentos empregados no discurso historiográfico, como o emprego da fonte, a preocupação com a preservação de um conhecimento sobre o passado histórico, o estabelecimento de uma relação causal entre passado e presente, e a construção material desse tempo histórico. É nesse ponto, isto é, na questão da materialidade, que a tradição antiquarianista é empregada na narrativa scottiana compondo um de seus aspectos mais característicos, que seria a visibilidade. A preocupação com a topografia, os monumentos, a decoração interior, os objetos, a linguagem, 0 vestuário, não são apenas convenções romanescas que pretendem atribuir uma cor

\footnotetext{
${ }^{45}$ Scott, Walter. "Waverley (1814). A Postscript Which Should Have Been a Preface". Op.Cit. p.4.

${ }^{46}$ Idem, Ibidem, p.4.
} 
local à narrativa, ao contrário, são elementos relacionados à figuração histórica. Os antiquarianistas, de acordo com Nietzche, "respiram um ar embolorado", ${ }^{47}$ metáfora que nos remete à dimensão sensorial da experiência pregressa. Essa característica concreta da representação histórica é extremamente importante na narrativa scottiana como via de acesso à visibilidade do passado.

A discussão sobre a articulação dos procedimentos do discurso historiográfico na narrativa romanesca percorre os textos críticos de Walter Scott. Em alguns prefácios encontramos a voz narrativa em primeira pessoa que assume esse caráter híbrido da narrativa, defendendo e explicando seu mecanismo intrínseco. Seus pares na defesa dessa tese são as personae Laurence Templeton e o Autor de Waverley. Do lado oposto, representando a tradição antiquarianista e o discurso historiográfico puro, sem conexões com a imaginação, estão Dr. Dryasdust e Captain Clutterbuck. As personae não só se distinguem em relação à postura adotada sobre o conhecimento histórico e como este deve ser tratado, mas também em sua caracterização, adotando um tom e linguagem específicos, dependendo de sua posição. Grosso modo, os antiquarianistas são muito formais e não economizam as expressões em Latim. Enquanto que as outras personae, as quais defendem o projeto de fundir história e ficção, são menos formais, mais irônicas e substituem a erudição pelos exemplos da vida prosaica. Vale lembrar que os nomes dos antiquarianistas fazem alusão ao que é velho e sem graça. Dryasdust, por exemplo, pode ser traduzido como "seco como pó" e Clutterback - mesmo que seja uma variação de Clutterbuck, um sobrenome mais comum - inclui o vocábulo clutter, que significa "amontoamento" e remete-nos às coleções antiquarianistas.

Para Walter Scott, a erudição e as coleções museológicas dos antiquarianistas sem a perspectiva crítica do processo histórico e a imaginação poética são "secas como pó". Contemporâneo de uma discussão ativa sobre a produção historiográfica, o autor escocês encontrou na fusão das diferentes práticas do conhecimento histórico com a literatura a sua maneira de pensar a história de seu país. Assim, a dimensão da narrativa scottiana está em consonância com a

\footnotetext{
${ }^{47}$ Citado por Stephen Bann. IN: The Inventions of History: Essays on the Representation of the Past. Op.Cit. p.110.
} 
afirmação de Pomian, quando ele diz que, para realizar seu objetivo, isto é, a reconstrução do passado, uma obra histórica segue três exigências: possibilitar que se conheça, compreenda e sinta; em suas palavras "faire savoir, faire comprendre e faire sentir." O teórico nos explica que o peso em uma das exigências varia em diferentes tipos de obras históricas. Maior ênfase na primeira exigência em monografias eruditas, na segunda em tratados, e na terceira nos romances, sendo exemplar a obra histórica que consiga equilibrar as três.

A função da imaginação para a representação histórica é discutida no prefácio do romance Peveril of the Peak, de 1822. Nesse prefácio, Walter Scott mobiliza três personae: o reverendo Dr. Dryasdust, o capitão Clutterbuck e o Autor de Waverley. O prefácio é uma reprodução epistolar, na qual o autor da epístola, Dr. Dryasdust, troca impressões com seu destinário, Cap. Clutterbuck, sobre o Autor de Waverley, reproduzindo o diálogo que havia travado com essa figura misteriosa; vale lembrar que a autoria dos romances naquela época era desconhecida. Um dos pontos marcantes do diálogo ocorre quando o autor da epístola discute com o Autor de Waverley as críticas que este recebera dos antiquarianistas contra seu projeto literário de fundir História e ficção. Para essa classe de eruditos, História e ficção não se misturam; o que é sério não se mistura à diversão, pois: "a investigação da verdade é uma tarefa especial" ("the investigation of truth is an especial duty") ${ }^{48}$. Em seguida, as personagens iniciam um debate sobre a possibilidade ou impossibilidade desse projeto literário. Os conceitos de reprodução histórica são definidos no diálogo por meio de metáforas, assim, ao atentarmos para essas metáforas, o mecanismo de reconstrução do passado empregado pelo autor na narrativa romanesca torna-se mais claro. O diálogo continua da seguinte forma:

Author. I understand you. You mean to say these learned persons will have but little toleration for a romance or a fictitious narrative founded upon history?

Dryasdust. Why, sir, I do apprehend that their respect for the foundation will be such that they may be apt to quarrel with the inconsistent nature of the superstructure; just as every classical traveller pours forth expressions of sorrow and indignation when, in travelling through Greece, he chances to see a Turkish kiosk rising on the ruins of an ancient temple.

Author. But since we cannot rebuild the temple, a kiosk may be a pretty thing, may it not? Not quite correct in architecture, strictly and classically criticized; but presenting something uncommon to the eye, and something fantastic to the imagination, on which the spectator

\footnotetext{
${ }^{48}$ Scott, Walter. "Prefatory Letter to Peveril of the Peak." The Prefaces to the Waverley Novels by Sir Walter Scott edited by Mark A. Weinstein. Op. Cit. p.64.
} 
gazes with pleasure of the same description which arises from the perusal of an Eastern tale. $^{49}$

A narrativa scottiana é representada na discussão entre as personae por um "quiosque turco". Para os olhos conservadores dos antiquarianistas, o passado deve ser reconstruído a partir das especificidades reais sem mediações com o imaginário. Assim, um templo grego deve ser reconstruído enquanto tal. Incorporar elementos imaginários à representação do passado a tornam destoante, assim como um "quiosque turco que se ergue sobre as ruínas de um templo antigo" na Grécia. Para o Autor de Waverley, o quiosque turco é uma bela reconstrução do passado, uma vez que produz sentimentos. Mesmo não sendo totalmente fidedigno, materializa o passado, possibilita a visualização desse mundo que já se foi. $O$ solo em que é construído é o mesmo em que se encontram as ruínas, ou seja, a fundação da narrativa também é a realidade histórica. Sendo assim, o quiosque turco é o resultado do encontro do referencial histórico com as convenções romanescas.

Walter Scott, em artigo crítico dedicado aos romances de Jane Austen, faz a seguinte afirmação sobre o objetivo principal de um romancista: "what, after all, is the immediate and peculiar object of the novelist, as of the poet, to please." Novamente, encontramos a mesma preocupação em entreter o leitor, tal como fora expressa no trecho acima. O que poderia parecer um truísmo adquire uma especificidade, no projeto literário de Walter Scott, que merece ser discutida. Segundo ele, possibilitar que o leitor "sinta", característica da ficção, ajuda-o a compreender e conhecer o passado, características da história. Ao insistir nesse aspecto, o autor está, na verdade, reafirmando a possibilidade da reconstrução do passado pela literatura, criando uma narrativa vívida da História.

Se, como vimos, a função da imaginação é abrir espaço para a visibilidade e, dessa maneira, para os sentidos e sentimentos do leitor, no prefácio a The Fortunes of Nigel, vislumbramos como é possível o conhecimento histórico no campo literário.

\footnotetext{
${ }^{49}$ Scott, Walter. "Prefatory Letter to Peveril of the Peak." The Prefaces to the Waverley Novels by Sir Walter Scott edited by Mark A. Weinstein. Op. Cit. p.65.

${ }^{50}$ Scott, Walter Sir. Critical and Miscellaneous Essays. Philadelphia: Carey \&Hart, 1841, vol.I, p.416.
} 
O prefácio segue a mesma estrutura daquele que acabamos de comentar, porém apresenta uma inversão entre remetente e destinatário. Desta vez, quem escreve a carta é Cap. Clutterback e Dr. Dryasdust é seu destinatário, e o conteúdo, novamente, gira em torno de um diálogo travado com o Autor de Waverley:

Dryasdust. I am unable to dispute with you in metaphor, sir; but I must say, in discharge of my conscience, that you stand much censured for adulterating the pure sources of historical knowledge. You approach them, men say, like the drunken yeoman who, once upon a time, polluted the crystal spring which supplied the thirst of his family, with a score of sugar loaves and a hogshead of rum; and thereby converted a simple and wholesome beverage into stupifying, brutifying, and intoxicating fluid, sweeter, indeed, to the taste than the natural lymph, but, for that very reason, more seductively dangerous.

(...)

Author. (...) I will explain. A poor fellow, like myself, weary with ransacking his own barren, and bounded imagination, looks out for some general subject in the huge and boundless field of history, which holds forth examples of every kind; lights on some personage, or some combination of circumstances, or some striking trait of manners, which he thinks may be advantageously used as the basis of a fictitious narrative; bedizens it with such colouring as his skill suggests, ornaments it with such romantic circumstances as may heighten the general effect, invests it with such shades of character as will best contrast with each other, and thinks, perhaps, he has done some service to the public, if he can present to them a lively fictitious picture, for which the original anecdote or circumstance which he made free to press into his service only furnished a slight sketch. Now I cannot perceive any harm in this. The stores of history are accessible to every one, and are no more exhausted or impoverished by the hints thus borrowed from them than the fountain is drained by the water which we subtract for domestic purposes. And in reply to the sober charge of falsehood against a narrative announced positively to be fictitious, one can only answer by Prior's exclamation-

Odzooks, must one swear to the truth of a song?

(...)

Dryasdust. But besides, and especially, it is said that you are in danger of causing history to be neglected, readers being contented with such frothy and superficial knowledge as they acquire from your works, to the effect of inducing them to neglect the severer and more accurate sources of information.

Author. I deny the consequence (...) The history of the divining-rod is well known: it is a slight, valueless twig in itself, but indicates, by its motion, where veins of precious metal are concealed below the earth, which afterwards enrich the adventurers by whom they are laboriously and carefully wrought. I claim no more merit for my historical hints; ${ }^{51}$

No trecho acima, Dr. Dryasdust critica a falta de fidelidade histórica encontrada nos romances do Autor de Waverley; acusa-o de adulterar "as fontes puras do conhecimento histórico", comprometendo, dessa forma, o real entendimento da história. Em resposta, o Autor de Waverley defende-se, ressaltando a improcedência da acusação, uma vez que o referencial da leitura está incorreto. Segundo ele, é um equívoco ler seus romances como tratados de História. No entanto, mesmo no campo fictício acredita ser possível transmitir o conhecimento histórico, uma vez que "os arquivos da história são acessíveis a

${ }^{51}$ Scott, Walter. "Prefatory Letter to Peveril of the Peak." Op. Cit. p.65-66. 
todos." Outra questão discutida diz respeito ao tipo de conteúdo que seria considerado histórico, questão que se mostra muito relevante para a compreensão do projeto literário de Walter Scott.

Que fatos, então, são, por ele, considerados históricos? Essa reflexão é um ponto crucial para alcançar a dimensão histórica da narrativa scottiana, pois revela qual é sua perspectiva sobre a História. Para o Autor de Waverley, a frivolidade da narrativa apontada pelos críticos é um problema de perspectiva. O que os críticos postulam como História é contestado pelo Autor; pois, para ele, a História diz respeito à mudança dos homens no tempo. O objeto de estudo da nova perspectiva histórica é a vida individual do homem de outrora - no nível prosaico - e é, também, a observação de sua alteridade em relação ao tempo presente. Portanto, Walter Scott indica um desejo de representar a vida humana em um tempo vivido, um tempo histórico. Segundo Paul Ricouer, a representação desse tempo histórico refere-se à vida humana que é "individual e coletiva". 52

Nesse sentido, o teor histórico nos romances de Walter Scott é outro, na medida em que eles lidam com novas dimensões e conteúdos na transmissão do conhecimento histórico. Motivo pelo qual Walter Scott compara sua narrativa a "uma vareta mágica" ("divining-rod"). O instrumento aludido por Walter Scott é utilizado por uma "ciência" antiga, denominada Radiestesia, para descobrir poços d'água e jazidas subterrâneas. Sendo assim, a comparação da narrativa com a "vareta mágica" é significativa, visto que ela também traz à superfície o que estava submerso, isto é, a vida humana pretérita em sua dimensão dialética do "individual" e do "coletivo". Para Scott, a História não se constitui apenas de grandes acontecimentos, ao contrário, é "um vasto e ilimitado campo" e contém "exemplos de todo tipo". Basta observar com atenção os indivíduos e seus costumes e, ali, encontrar material riquíssimo para a criação de um "retrato ficcional vívido" do passado.

52 Citado por José Carlos Reis. IN: Reis, José Carlos. História \& Teoria. Historicismo, Modernidade, Temporalidade e Verdade. Rio de Janeiro: Editora FGV, 2006, p. 184. 
A metáfora da "vareta mágica" utilizada por Walter Scott é perfeitamente aplicada, pois a visada histórica da narrativa scottiana dedica-se à história do homem comum, do reflexo dos grandes acontecimentos históricos coletivos no plano individual, muito bem definido por Ann Rigney como a história da cultura do dia-a-dia. ${ }^{53}$ Essa perspectiva histórica, no século $\mathrm{XIX}$, era considerada uma descoberta. A representação histórica na narrativa scottiana é concentrada nesse enquadramento - a dialética entre o individual e o coletivo - que deve ser construído de maneira a estimular a impressão do leitor. Podendo, o leitor, atingir o conhecimento histórico pela visibilidade do passado recriado na narrativa.

3- Um conjunto coerente.

Cremos ter estabelecido, até aqui, a relação entre os procedimentos do discurso historiográfico e a narrativa romanesca nos textos críticos de Walter Scott. Interessa-nos, agora, analisar detalhadamente o aproveitamento do referencial histórico na narrativa romanesca, isto é, esclarecer os mecanismos da reprodução histórica aliados às convenções romanescas.

Iniciamos pelo prefácio de Ivanhoe, o qual nos ajuda a pontuar algumas questões diretamente relacionadas à construção formal do romance. Nesse prefácio, novamente em forma epistolar, a persona Laurence Templeton defende o projeto literário do autor do romance contra as críticas de Dr. Dryasdust. Nesse romance em particular, a tese defendida por Templeton vai se mostrar muito significativa para nossa análise, uma vez que o argumento é estabelecer quais pontos da realidade histórica são essenciais na construção da narrativa.

\footnotetext{
${ }^{53}$ Segundo definição da crítica: "This meant not only the readers could be invited to identify with the hopes and frustrations of individuals as the events unfold but the novelist could extend his representation of the period into the culture of everyday life, which forms the background of political events." IN: Rigney, Ann. Imperfect Histories: The Elusive Past and the Legacy of Romantic Historicism. Ithaca: Cornell University Press, 2001, p.28. Itálico nosso: "Isso significou que os leitores poderia não somente ser convidados a se indentificar com as esperanças e frustrações dos indivíduos, com o desenvolvimento dos acontecimentos, mas também o romancista poderia estender sua representação do período para a cultura do dia-a-dia, a qual constitui o pano de fundo dos acontecimentos politicos."
} 
Ivanhoe diferencia-se dos outros romances da série do Waverley Novels, pois há um distanciamento maior no tempo e a realidade histórica retratada não é a escocesa, mas a inglesa. Para Dr. Dryasdust, a mudança no tempo e espaço é desvantajosa para o autor, que terá acesso a um "material histórico" escasso, haja vista que o processo civilizatório na Inglaterra "há muito se concretizou". Enquanto que, ao tratar da realidade escocesa, o autor é privilegiado, uma vez que muitos escoceses, ainda vivos, "lembram-se bem de pessoas que não somente tinham visto o célebre Roy M'Gregor, mas haviam festejado e lutado com ele." O antiquarianista prossegue com sua premissa, indicando 0 perigo de "improbabilidades" no qual incorrerá o autor. Templeton, por sua vez, admite a dificuldade da empreitada devido à escassez do "material histórico", porém, segundo ele, as objeções são "mais formais do que substanciais". A falta de material e de testemunhas não impede que o autor represente o passado, pois, como o romance não é um tratado histórico, o autor é capaz, mesmo com poucos dados concretos, de ter acesso ao aspecto essencial do tempo vivido e de iluminar "alguns aspectos da vié privée" de seus antepassados. A narrativa romanesca pode, então, representar o tempo vivido intercalando a essência da realidade histórica com a imaginação:

Still, the severer antiquary may think that, by thus intermingling fiction with truth, I am polluting the well of history with modern inventions, and impressing upon the rising of a generation false ideas of the age which I describe. I cannot but in some sense admit the force of this reasoning, which I yet hope to traverse by the following considerations. ${ }^{54}$

A partir desse ponto, as considerações feitas por Templeton, em defesa do uso da história pela literatura, mobilizarão aspectos formais do romance, evidenciando como a prática historiográfica se articula na fatura romanesca. Um primeiro aspecto discutido refere-se ao uso da linguagem, a qual, segundo a ótica "formal" antiquarianista, deve ser preservada e reproduzida literalmente como se encontra nos manuscritos antigos. A mesma postura não é adotada no projeto de fundir história e ficção:

The license which I would here vindicate is so necessary to the execution of my plan, that I will crave your patience while I illustrate my argument a little farther.

\footnotetext{
${ }^{54}$ Scott, Walter. "Ivanhoe: Dedicatory Epistle." Op. Cit. p.33.
} 
(...) If our neophyte, strong in the new-born love of antiquity, were to undertake to imitate what he had learnt to admire, it must be allowed he would act very injudiciously if he were to select from the glossary the obsolete words it contains, and employ these, exclusively of all phrases and vocables retained in modern days. This was the error of the unfortunate Chatterton. In order to give his language the appearance of antiquity, he rejected every word that was modern, and produced a dialect entirely different from any that had ever been spoken in Great Britain. He who would imitate an ancient language with success must attend rather to its grammatical character, turn of expression, and mode of arrangement, than labour to collect extraordinary and antiquated terms. (...).

What I have applied to language, is still more justly applicable to sentiments and manners. ${ }^{55}$

Para Templeton, a linguagem antiga deve estar presente na caracterização das personagens; entretanto, o autor que pretende se aventurar na reconstrução do passado deve atentar para o "caráter gramatical, o tom das expressões, e o modo de ordenamento" desse linguajar. Isso porque, se este se ativer exclusivamente à "coleta de termos antigos e extraordinários", seu texto torna-se ilegível. O mesmo deve ser aplicado aos sentimentos e costumes das personagens, uma vez que, assim como a linguagem, os sentimentos humanos não se modificam completamente ao longo do tempo e o ciúme de outrora é o mesmo de hoje. Dessa forma, cabe ao autor respeitar essas características essenciais e universais da vida humana e iluminá-la com os detalhes particulares do tempo vivido, encontrado nas fontes históricas.

Além da linguagem, a prática antiquarianista pode ajudar na reconstrução visual do passado pela apreciação do aspecto material da vida humana. Sem as "coleções" antiquarianistas seria impossível vislumbrar a materialidade da vida. Os aspectos concretos do passado permitem ao leitor recuperar, no campo sensorial, o tempo vivido. No entanto, todo esse acervo "museológico" deve estar em concordância com as convenções romanescas, isto é, deve fazer sentido na trama e na caracterização das personagens.

A questão será como estruturar a narrativa em torno da visibilidade do passado. Para o narrador scottiano, a visibilidade é possível graças à noção de enquadramento. Como o fato histórico existe per se, porque é um fato finito, e o narrador não é testemunha desse momento, representá-lo requer uma observação plástica. O passado é fixo como um quadro. É necessário recuperar o delineamento

\footnotetext{
${ }^{55}$ Scott, Walter. "Ivanhoe: Dedicatory Epistle." Op. Cit. p. 35.
} 
da sua materialidade para que a distância no tempo seja vencida. O romance, então, é enquadrado na realidade histórica, possibilitando ao leitor apreciá-lo como a um quadro:

To take an illustration from a sister art, the antiquarian details may be said to represent the peculiar features of a landscape under delineation of the pencil. His feudal tower must arise in due majesty; the figures which he introduces must have the costume and character of their age; the piece must represent the peculiar features of the scene which he has chosen for his subject, with all its appropriate elevation of rock, or precipitate descent of cataract. His general colouring, too, must be copied from nature. The sky must be clouded or serene, according to the climate, and the general tints must be those which prevail in a natural landscape. So far the painter is bound down by the rules of his art to a precise imitation of the features of Nature; but it is not required that he should descend to copy all her more minute features, or represent with absolute exactness the very herbs, flowers, and trees with which the spot is decorated. These, as well as all more minute points of light and shadow, are attributes proper to scenery in general, natural to each situation, and subject to the artist's disposal, as his taste or pleasure may dictate.

It is true, that this license is confined in either case within legitimate bounds. The painter must introduce no ornament inconsistent with the climate or country of his landscape; he must not plant cypress trees upon Inch Merrin, or Scottish firs among the ruins of Persepolis. ${ }^{56}$

A reconstrução material do tempo histórico segue uma regra de coerência. Nas Artes Plásticas, o pintor retém da natureza a realidade material do seu quadro, no entanto, o movimento, a "vida" da obra, provém do jogo de luz e sombra criado pela imaginação do artista. Como o referencial da intriga romanesca é o passado histórico, comparado nesse trecho à "natureza", cabe ao narrador entremear a representação histórica com a intriga, sendo livre na disposição dos elementos reconstruídos a partir do referencial histórico. Contudo, o autor deve respeitar uma regra: a coerência entre história e ficção, dois eixos constitutivos desse gênero literário. Da mesma maneira que o pintor não está autorizado a introduzir elementos que originalmente não pertencem à paisagem, o narrador deve obedecer à lei da coerência em sua narrativa. Sendo assim, os elementos que constituem o passado histórico, como lugares, acontecimentos, instituições, crenças, costumes, vestimentas, linguagem, sentimentos, enfim, todos os elementos que fazem parte da cultura de uma época devem compor um todo coerente. Krzysztof Pomian denomina essa hierarquia relacional entre os elementos contextuais e o deslocamento temporal como um "conjunto coerente" (faisceau coherent). Para o teórico, o romance histórico exige a compatibilidade entre o contexto e o tempo, entre "a vida

\footnotetext{
${ }^{56}$ Scott, Walter. "Ivanhoe: Dedicatory Epistle". Op. Cit. p.36-37.
} 
íntima e o ambiente exterior". 57 De que maneira, então, o narrador-historiador scottiano constrói sua representação histórica, respeitando o princípio de coerência?

A resposta está na estrutura do romance, o qual é construído como um microcosmo que se organiza em torno de um fato histórico, finito, que será mesclado à criação de personagens e intrigas fictícias. Os componentes fictícios estarão sempre subordinados ao contexto histórico retratado na narrativa. Aqui concordamos com Balzac, que compreendeu exatamente o mecanismo de representação histórica no romance scottiano, quando define o fato histórico como o "sol desse microcosmo" e os componentes fictícios, "sua constelação".

Quel que soit le nombre des accessoires et la multiplicité des figures, un romancier moderne doit, comme Walter Scott, l'Homère du genre, les grouper d'après leur importance, les subordonner au soleil de son système, un intérêt ou un héros, et les conduire comme une constellation brillante dans un certain ordre. ${ }^{58}$

A reconstrução do passado se produz, então, na descrição dos efeitos que o dado real causará na vida cotidiana das personagens. Em outras palavras, percebemos como as personagens foram, em sua vida prosaica, afetadas pelas transformações históricas, independentemente da exata reprodução do evento histórico, e graças ao deslocamento do que é somente público para o âmbito da vida privada. O narrador-historiador scottiano preocupa-se mais com o movimento dialético entre o individual e o coletivo do que com a exatidão dos detalhes do evento histórico. ${ }^{59}$

${ }^{57}$ Pomian, Krzysztof. "Histoire et Fiction". Op. Cit. p.115.

${ }^{58}$ Balzac. "Lettres sur la littérature, le theâtre et les arts". Écrits Sur Le Roman. Textes choisis, présentés et annotés par Stéphane Vachon. Paris: Le Livre De Poche, 2000, p.149.

${ }^{59}$ Sobre esse conceito, Ann Rigney aponta duas modalidades de representação histórica definidas por Nancy Partner: aquela que é fiel à realidade histórica (os detalhes históricos são exatos) e aquela que é fiel à significação (a interpretação analítica do fato histórico é correta). A diferença entre a verdade dessas representações diz respeito ao tipo de autoridade em que se baseiam; sendo assim, a primeira tem como base um sólido conjunto de evidência, enquanto que a segunda tem como base a coerência e eficácia do processo analítico. As duas modalidades não são excludentes, e quanto mais se verifica correção em ambos os lados, mais satisfatória se afigura a representação histórica. Rigney afirma que, na narrativa "híbrida" de Walter Scott, a representação histórica é mais fiel à significação : "In arrogating to himself as a novelist the freedom to invent the particulars of his story, Scott reneged on the claim to be fully and literally true-to-actuality since he did not bind himself to respect particular facts. But he did not thereby renege on the claim to have represented Scottish history in such a way as to be true-to-its-meaning, and indeed, far from abandoning actuality entirely, he martialed considerable historical knowledge to underwrite his claim." IN: Rigney, Ann. Op.Cit.p.26: "Ao se atribuir, enquanto romancista, a liberdade de inventar as particularidades da sua história, Scott 
A formação das personagens segue o princípio de coerência que discutimos acima, porque elas adquirem um contorno psicológico em razão do ambiente histórico retratado. A definição lukacsiana das personagens "tipo", referente às personagens de Walter Scott, insere-se na lógica da representação histórica realizada pelo autor escocês. Segundo o crítico, o "tipo" representa um amplo movimento histórico, encarnado na sua condição humana particular. As figuras que povoam a representação histórica na narrativa romanesca são produtos do imaginário, contudo sua significação é pautada em um conhecimento histórico da realidade. Dessa maneira, as personagens vão sendo "coloridas" com a realidade da vida material, adquirida a partir das fontes históricas antiquarianistas, e ganhando significação histórica quando sua vida é atravessada pelo processo histórico. É exatamente essa articulação presente no delineamento das personagens "tipo" que as torna exemplos concretos da fusão proposta pelo projeto scottiano, pois, mesmo que sejam uma construção fictícia, sua essência alinha-se com a verdade histórica. A formação das personagens, que está diretamente relacionada ao contexto histórico de uma época, permite um conhecimento da realidade, tornando-as personagens vivas, como afirma Agnes Heller:

The eternal validity of historically evolved formations, a fact in itself, would not be conceivable
if we did not assume that in their individuality they represent at the same time the essence of
our species: as human beings, we encounter our own selves in their protagonists and
destinies. They speak to us because through them we are able to speak to our selves.

A composição das personagens scottianos está diretamente relacionada a esse tipo "novo" de representação histórica, o qual seria, segundo Scott, responsável pelo sucesso de seus romances:

renunciou à alegação de ser total e literalmente verdadeiro em relação à realidade, visto que ele não se compromete a respeitar a particularidade dos fatos. Mas, ele não renunciou, desse modo, à reivindicação de ter representado a história da Escócia de forma a ser verdadeiro em relação ao seu significado, e de fato, longe de abandonar a realidade inteiramente, ele corajosamente mostrou considerável conhecimento histórico para assegurar sua reivindicação."

${ }^{60}$ Heller, Agnes. "Lukács' Later Philosophy". IN: Lukács Reappraised. Edited by Agnes Heller. New York: Columbia University Press, 1983, p. 185: "A eterna validade das formações historicamente desenvolvidas, um fato em si mesmo, não seria concebível se nós não presumíssemos que em sua individualidade elas representam, ao mesmo tempo, a essência de nossa espécie: como seres humanos, deparamos com nós mesmos em seus protagonistas e destinos. Eles falam conosco porque através deles somos capazes de falar a nós mesmos." 
We do not know if the imagination of our author will sink in the opinion of the public when deprived of that degree of invention which we have hitherto disposed to ascribe to him; but we are certain that it ought to increase the value of his portraits, that human beings have actually sate for them. These coincidences between fiction and reality are perhaps the very circumstances to which the success of these novels is in a great measure to be attributed; for, without depreciating the merit of the artist, every spectator at once recognizes in those scenes and faces which are copied from nature an air of distinct reality, which is not attached to fancy-pieces however happily conceived and elaborately executed. ${ }^{61}$

Há duas passagens em Waverley ${ }^{62}$ que nos parecem exemplares da ideia do conjunto coerente que discutimos anteriormente. Trata-se do encontro de Edward Waverley com o dissidente jacobita Fergus Mac-Ivor e de sua participação em um banquete realizado na propriedade deste último. Essa oportunidade the permite observar os costumes dos Highlanders. As passagens referidas encontram-se, respectivamente, nos capítulos intitulados "O Chefe e sua Mansão" e "Um Banquete das Terras Altas"63. No capítulo "O Chefe e sua Mansão", o narrador nos apresenta a personagem Fergus e, no capítulo seguinte, os detalhes da vida prosaica dos Highlanders. Em "O Chefe e sua Mansão" temos o seguinte retrato de Fergus:

\begin{abstract}
Had Fergus Mac-Ivor lived Sixty Years sooner than he did, he would, in all probability, have wanted the polished manners and knowledge of the world which he now possessed; and had he lived Sixty Years later, his ambition and love of rule would have lacked the fuel which his situation now afforded.(...)

In following this course of conduct, Fergus had a further object than merely being the great man of his neighbourhood, and ruling despotically over a small clan. From his infancy upward, he had devoted himself to the cause of the family, and had persuaded himself, not only that their restoration to the crown of Britain would be speedy, but that those who assisted them would be raised to honour and rank. It was with this view that he labored to reconcile the Highlanders among themselves, and augmented his own force to the utmost, to be prepared for the first favourable opportunity of rising. ${ }^{64}$
\end{abstract}

${ }^{61}$ Scott, Walter. "Review of Tales of My Landlord". Op. Cit.p.13-14. Itálico nosso.

${ }^{62} \mathrm{O}$ romance retrata a rebelião jacobita de 1745 que objetivava destronar a dinastia Hanover e restaurar a dinastia Stuart na figura de Edward Stuart. Edward Waverley, personagem central do romance, é inglês e filho de um partidário dos Hanover. Devido à indiferença de seu pai, é educado pelo tio simpatizante da causa jacobita. Avesso às instabilidades políticas da época e mais preocupado com questões artísticas, Waverly é obrigado a seguir a carreira militar e no ano de 1745 recebe uma ordem de missão na Escócia. Em um período de licença decide visitar o amigo de seu tio, o jacobita Barão de Bradwardine. Na casa do Barão, iniciam-se as aventuras do jovem Waverley, o qual, imbuído de um espírito aventureiro viaja às Terras Altas. Durante a viagem, Waverley deparase com uma realidade muito diferente da sua e acaba por se aliar à causa jacobita liderada por Fergus Maclvor.

${ }^{63}$ No original "The Chief and His Mansion" e "A Highland Feast".

${ }^{64}$ Scott, Walter. Waverley. London: Penguin Popular Classics, 1994, p.165-167. 
A personalidade de Fergus Mac-Ivor harmoniza-se com o período histórico e com a estrutura interna do romance, pois ele pertence tanto a um plano políticosocial aristocrático, visto que é um nobre, quanto a um plano popular, enquanto líder dos rebeldes e membro de um clã. A história pessoal de Fergus se confunde com o processo histórico dos clãs escoceses:

The ancestor of Fergus Mac-Ivor, about three centuries before, had set up a claim to be recognised as chief of the numerous and powerful clan to which he belonged, the name of which it is unnecessary to mention. Being defeated by an opponent who had more justice, or at least more force, on his side, he moved southwards, with those who adhered to him, in quest of new settlements, like a second Æneas. ${ }^{65}$

O narrador prossegue nos informando dos detalhes da trajetória de seu bravo ancestral, cujo sobrenome Ivor, passou a denominar o clã.

The descendants of this worthy were so proud of him, that the reigning chief always bore the patronymic title of Vich lan Vohr, i.e., the son of John the Great; while the clan at large, to distinguish them from that from which they had seceded, were denominated Sliochd nan Ivor, the race of Ivor. 66

Em seguida, é narrada a história de sua família. Seu pai era descendente direto dos chefes do clã Ivor e em 1715 se alia aos Stuart na primeira rebelião jacobita. Em razão do fracasso de tal insurreição, seu pai parte para a França e se casa com uma dama da corte daquele país. Sendo assim, a história da personagem é coerente com o contexto histórico e, por isso, Fergus Mac-Ivor possui ao mesmo tempo "savoir-faire" e truculência, sem que isso pareça improvável. Para a intriga romanesca a dualidade na composição da personagem permite que os leitores tenham acesso ao conhecimento histórico dos dois mundos dos rebeldes dissidentes: a aristocracia e a população dos clãs, cada qual com suas honrarias e defeitos.

Das questões históricas e sócio-políticas do episódio, passamos à visibilidade da vida dos rebeldes isolados nas terras altas. Do plano contextual ao concreto, o leitor pode compreender e sentir o tempo vivido:

\footnotetext{
${ }^{65}$ Scott, Walter. Waverley. London: Penguin Popular Classics, 1994, p.164.

${ }^{66}$ Idem, Ibidem, p.164.
} 
Ere Waverley entered the banqueting hall, he was offered the patriarchal refreshment of a bath for the feet, which the sultry weather, and the morasses he had traversed, rendered highly acceptable. He was not, indeed, so luxuriously attended upon this occasion as the heroic travellers in the Odyssey; the task of ablution and abstersion being performed not by a beautiful damsel, trained

To chafe the limb, and pour the fragrant oil,

but by a smoke-dried skinny old Highland woman, who did not seem to think herself much honoured by the duty imposed upon her, but muttered between her teeth. "Our father's herds did not feed so near together, that I should do you this service". A small donation, however, amply reconciled this ancient handmaiden to the supposed degradation.(...)

This hospitality, apparently unbounded, had yet its line of economy. Some pains had been bestowed in dressing the dishes of fish, game, \&c., which were at the upper end of the table, and immediately under the eye of the English stranger. Lower down stood immense clumsy joints of mutton and beef, which, but for the absence of pork, abhorred in the Highlands, resembled the rude festivity of the banquet of Penelope's suitors. But the central dish was a yearling lamb, called "a hog in har'st", roasted whole. It was set upon his legs, with a bunch of parsley in its mouth, and it was probably exhibited in that form to gratify the pride of the cook, who piqued himself more on the plenty than the elegancy of his master's table. The sides of this poor animal were fiercely attacked by the clansmen, some with dirks, others with the knives which were usually in the same sheath with the dagger, so it was soon rendered a mangled and rueful spectacle. (...)

The liquor was supplied in the same proportion, and under similar regulations. Excellent claret and champagne were liberally distributed among the Chief's immediate neighbours; whisky, plain and diluted, and strong beer, refreshed those who sat near the lower end. ${ }^{67}$

A trajetória de Waverley guarda alguma semelhança com a de Ulisses. Como o herói da epopeia grega, é um viajante e por onde passa se depara com paisagens distintas. Entretanto, a comparação termina aqui, pois estamos diante de gêneros narrativos diferentes. Desse modo, Waverley guarda uma diferença marcante em relação a Ulisses: ele não é um herói, é antes um observador, uma testemunha, por cujos olhos os leitores entram em contato com o tempo histórico do passado. Desprovido de um caráter mítico e guerreiro, é um homem mediano que vivencia as experiências desse passado vivido, ou seja, Waverley está inserido nesse tempo histórico. Sobre o motivo de compor as personagens dessa maneira, Walter Scott afirma:

In addition to the loose and incoherent style of the narration, another leading fault in these novels is the total want of interest which the reader attaches to the character of the hero. Waverley, Brown, or Bertram in Guy Mannering, and Lovel in the Antiquary, are all brethren of a family; very amiable and very insipid sort of young men. We think we can perceive that this error is also in some degree occasioned by the dramatic principle upon which the author frames his plots. His chief characters are never actors, but always acted upon by the spur of circumstances, and have their fates uniformly determined by the agency of the subordinate persons. $^{68}$

\footnotetext{
${ }^{67}$ Scott, Walter. Waverley. Op. Cit. p.170-171.

${ }^{68}$ Scott, Walter. "Review of Tales of My Landlord." Op. Cit. p.15.
} 
Ao afirmar que as personagens nunca são os agentes das ações, mas aqueles que sofrem suas conseqüências, Walter Scott expõe os meandros de uma construção narrativa que objetiva reconstruir o passado histórico:

\begin{abstract}
A ênfase na ação coletiva faz Scott sistematicamente operar um esvaziamento do papel do herói, cuja atuação obedece a parâmetros de outra ordem, pois a ele cabe não só representar o processo histórico como mediar entre forças sociais em oposição no romance. Para isso, Scott o concebe antes como um observador desinteressado do que como agente - uma espécie de "terreno neutro" onde se dá o encontro entre os campos sociais ou políticos em luta - e que, sintetizando as particularidades da época representada, funciona como elo de ligação entre o plano individual e geral. ${ }^{69}$
\end{abstract}

O leitor, juntamente, com esses heróis "medianos", observa o processo histórico. A narrativa romanesca lhe permite, então, compreender, conhecer e sentir o tempo vivido.

Portanto, quem lava os pés de Waverley não poderia mesmo ser uma bela donzela, mas o tipo social que, obedecendo à coerência sócio-política da época, seria capaz de submeter-se a esse encargo: "uma mulher velha, seca e enrugada das terras altas". E ainda o faz a contragosto, visto que Waverley é inglês. A mulher somente se acalma mediante "uma pequena contribuição". A cena continua e é possível notar a organização das diferentes classes sociais, os aristocratas e os homens mais simples da população, que conviviam em uma relativa harmonia em razão de uma particularidade histórica. As diferenças sociais, os costumes, o "savoir-faire" dos chefes e a brutalidade dos homens dos clãs são retratados na descrição do banquete. À disposição dos lugares à mesa e o que consomem, corresponde o lugar que cada classe ocupa. Assim, na extremidade em que se encontra Waverley "algum capricho havia sido conferido à apresentação dos pratos", enquanto que, no extremo oposto da mesa, "encontravam-se fartas porções de carne de carneiro e boi, dispostas grosseiramente", e consumidas de forma brusca pelos homens do clã com "punhais" e "facas". Os objetos, as ações, a comida, a bebida, tudo pode ser visualizado e, até, reproduzido num nível sensorial, nesse quadro histórico do passado. Destituída de seu referencial histórico, a cena poderia resvalar para a paródia, porém o que predomina é antes o reconhecimento

\footnotetext{
${ }^{69}$ Vasconcelos, Sandra Guardini Teixeira. "Figurações do passado: o romance histórico em Walter Scott e José de Alencar". Terceira Margem. Rio de Janeiro, 2008, v.12, n.18, p.23.
} 
de um modo de vida circunscrito em um período histórico específico. Assim como Waverley, os leitores têm uma reação de "veja como esses homens viviam".

Até aqui, discutimos apenas os prefácios originais, que se diferenciam daqueles da edição da Magnum Opus. Como já mencionado anteriormente, estes últimos prefácios são em sua maioria assinados por Walter Scott, não havendo, dessa forma, o jogo com a autoria narrativa. Os prefácios para a Magnum Opus, por sua vez, são partes de um todo, pois estão inseridos em um projeto editorial. Nesse sentido, seguem uma linha mestra de discussão: a apresentação da realidade histórica e sua relação com o romance que introduzem. Geralmente, os prefácios para a Magnum Opus indicam como o autor entra em contato com o fato histórico e a maneira como este será "trabalhado" no romance. Em nenhum momento, o autor ilude o leitor a esse respeito: o romance é sempre o resultado da fusão entre a realidade do fato histórico e a imaginação.

De modo geral, o conteúdo dos prefácios para a Magnum Opus segue uma sequência argumentativa. Primeiramente, há a apresentação do fato histórico a ser abordado - que pode ser um relato de alguém que testemunhou um acontecimento ou conheceu as personagens, o fruto de uma pesquisa em documentos históricos, ou até sua memória. Em seguida, temos a narrativa detalhada de como se deu o fato na realidade. Após a explanação, inicia-se o romance que será outra narrativa sobre o mesmo acontecimento histórico. O que é dado, documento, pesquisa transforma-se em experiência revivida.

O prefácio de The Heart of Midlothian é um bom exemplo desse procedimento, visto que ali Walter Scott descreve detalhadamente a fonte histórica de seu romance, iniciando, a seguir, sua narrativa baseada na realidade histórica. $O$ referencial histórico do romance diz respeito à vida de Helen Walker, cuja biografia é informada ao autor por Miss Helen Lawson, habitante do mesmo distrito da personagem histórica. Scott nos informa todos os detalhes sobre Miss Lawson: nome, estado civil, nome do marido e região em que reside. Agindo dessa forma, o teor da comunicação que será reproduzida em seguida adquire um tom menos ficcional e temos a impressão de que realmente tal senhora conhecera Helen Walker. Os dados oferecidos por Walter Scott sobre Miss Lawson são bem 
verossímeis, porém não é possível atestar a veracidade de sua existência. Se tal senhora existiu ou não, se conheceu Helen Walker ou não, é um fator de menor importância. O que importa é a contextualização histórica sobre a personagem, Helen Walker, que de fato existiu e é relevante para o romance.

Nesse sentido, o relato de Miss Lawson reproduzido por Walter Scott poderia ter sido realizado por qualquer outro habitante da cidadezinha onde Helen Walker viveu seus últimos dias, mais precisamente, em Irongray, na região de Dumfries, sul da Escócia. Nessa pequena cidade, Walter Scott ergueu uma lápide em homenagem a Helen Walker no cemitério da paróquia, contendo a inscrição:

\author{
THIS STONE WAS ERECTED \\ BY THE AUTHOR OF WAVERLEY, \\ TO THE MEMORY \\ OF \\ HELEN WALKER \\ WHO DIED IN THE YEAR OF GOD 1791 \\ THIS HUMBLE INDIVIDUAL \\ PRACTISED IN REAL LIFE \\ THE VIRTUES \\ WITH WHICH FICTION HAS INVESTED \\ THE IMAGINARY CHARACTER OF \\ JEANIE DEANS \\ REFUSING THE SLIGHTEST DEPARTURE \\ FROM VERACITY \\ EVEN TO SAVE THE LIFE OF A SISTER: \\ SHE NEVERTHELESS SHOWED HER \\ KINDNESS AND FORTITUDE, \\ IN RESCUING HER \\ FROM THE SEVERITY OF THE LAW, \\ AT THE EXPENSE OF PERSONAL EXERTIONS \\ WHICH THE TIME RENDERED AS DIFFICULT \\ AS THE MOTIVE WAS LAUDABLE \\ RESPECT THE GRAVE OF POVERTY, \\ WHEN COMBINED WITH THE LOVE OF TRUTH \\ AND DEAR AFFECTION ${ }^{70}$
}

Nessa inscrição, encontra-se resumidamente a essência da trajetória do sujeito histórico que se tornou um modelo para a construção imaginária da personagem Jeanie Deans: sua ética em contraste com o retrato histórico da Moral e do Direito. Scott percebe na biografia de Helen Walker e em seu caráter aspectos morais que condiziam com o momento histórico em que vivia, ou seja, o

\footnotetext{
${ }^{70}$ Citado por Ann Rigney no capítulo "The Case of Sir Walter Scott". IN: Rigney, Ann. Op. Cit. p.13.
} 
puritanismo, a mentalidade de uma mulher do povo escocês em contraste com a esfera política da época. A essência da experiência histórica permanece no romance, enquanto que os detalhes prosaicos da trajetória da personagem são modificados de acordo com os interesses internos da narrativa romanesca.

A construção da lápide é muito simbólica, pois, como afirma Ann Rigney, ela é uma "evidência concreta do fato de que a experiência real pode ser a fonte de histórias fictícias e que a ficção, por sua vez, é capaz de influenciar nossa memória do que foi real." História e ficção estão, dessa forma, simbolizadas na pedra, no encontro dos nomes de Helen Walker e Jeanie Deans. Uma nunca substituirá a outra, mas dividem a mesma essência do momento histórico representado.

Assim, os detalhes biográficos de Helen Walker são modificados no romance. A heroína real era filha de um fazendeiro que, após a morte do pai, se viu obrigada a cuidar de sua mãe e da irmã mais nova, Isabella, com o esforço de seu próprio trabalho. Helen perde ainda sua mãe e torna-se completamente responsável pela sua sobrevivência e a de sua irmã. Posteriormente, Isabella é julgada e condenada à pena de morte por infanticídio. Ao se negar a realizar um falso testemunho, que libertaria Isabella, Helen aproveita o espaço de seis semanas entre a sentença e a condenação, como era prescrito pela lei da época, e segue a pé até Londres para conseguir o perdão para a irmã, o qual, finalmente, é concedido. A vida prossegue para as irmãs Walker: Isabella se casa com o rapaz que a havia "desonrado" e Helen permanece solteira, vivendo solitária e humildemente ${ }^{71}$. No romance The Heart of Midlothian, os fatos da vida de Jeanie Deans são completamente modificados. Jeanie mora com o pai e a irmã, Effie, e ao final do romance se casa e tem filhos. Effie, ao contrário, leva uma vida solitária e triste após a morte de marido e de seu único filho.

Ao contrastar as duas narrativas de um mesmo fato, Walter Scott evidencia a diferença entre o historiador e o narrador-historiador. Harry E. Shaw salienta a importância do foco narrativo nesse tipo de narrativa que pretende fundir História e

${ }^{71}$ Sobre a biografia de Helen Walker ver o capítulo "Sisterly Affection". IN: Starling, Elizabeth. Noble Deeds of Woman; or, Examples of Female Courage and Virtue. Boston, MA: Phillips, Sampson \& Co., 1850, p.66-69. 
ficção, considerada pelo crítico como uma oscilação entre o mundo real e imaginário:

The oscillation Scott enacts in his novels is relevant to the problem of encountering other cultures. It raises a central hermeneutical and epistemological dilemma that faces any representation informed by the insights of historicisms: the problem of how, given the historical notion that is embedded in culture, we can nonetheless achieve and transmit a view of life that transcends it. Reality for the historicist always involves a radical particularity as an indispensable element and perhaps as its keynote; but once you've given the specific "contingent" this kind of status, the problem of emerging from it in a larger view becomes vexed. The formal category where this problem makes itself most obviously felt in prose fiction must involve narrative focus or point of view - the space the narrator occupies the space he allocates to his characters and to us, and the relationship between these. ${ }^{72}$

Enquanto o historiador reconstrói o passado e submete sua narrativa a "um controle de sua adequação à realidade extratextual do passado de qual ela trata"73, o narrador-historiador está livre desse controle. Contudo, assim como o historiador, o narrador não foi testemunha dos acontecimentos e para reproduzi-los constrói uma narrativa na qual apresentará ao leitor uma personagem que será a "testemunha" dos acontecimentos, a partir de um ângulo muito próximo da vida prosaica do momento histórico em questão, possibilitando ao leitor a "visibilidade" do tempo histórico. Dessa forma, Jeanie Deans, em sua trajetória, vai nos revelar o tempo vivido.

\footnotetext{
72 Shaw, Harry E. "Scott: Realism and the Other". IN: Narrating Reality. Austen, Scott, Eliot. Ithaca and London: Cornell University Press, 1999, p. 188: "A oscilação que Scott encena em seus romances é relevante ao problema do encontro com outras culturas. Suscita um dilema hermenêutico e epistemológico central que enfrenta qualquer representação informada pelos insights do historicismo: o problema de como, haja vista a noção histórica incrustada na cultura, somos capazes, não obstante, de alcançar e transmitir um visão sobre a vida que a transcenda. A realidade para 0 historicista sempre envolve uma particularidade radical como um elemento indispensável e talvez como sua tônica. Contudo, uma vez que se dê ao "contigente" específico este tipo de status, o problema de emergir dele, a partir de uma visão mais ampla, torna-se controverso. A categoria formal em que este problema se mostra mais obviamente perceptível, na prosa de ficção, deve envolver o foco narrativo ou ponto de vista - o espaço que o narrador ocupa, o espaço que ele concede aos seus personagens e a nós, e ao relacionamento entre estes."

73 "En bref, une narration se donne pour historique quand elle afiche l'intention de se soumettre à un contrôle de son adéquation à la réalité extratextuelle passé dont elle traite." IN : Pomian, Krzysztof. "Histoire et Fiction", Op. Cit. p.120: "Uma narração se diz histórica quando ela evidencia a intenção de se submeter a um controle de sua adequação à realidade extratextual do passado do qual ela trata."
} 
The Hearth of MidLothian ${ }^{74}$ inicia com um evento histórico: o levante de Porteous - The Porteous Riot - em que o capitão John Porteous é brutalmente linchado pela multidão. Essa personagem histórica, na tentativa de conter a população contrária ao enforcamento de dois ladrões, age de maneira opressiva e ordena que a guarda dispare contra a multidão.

A partir desse acontecimento, é retratada uma constelação de personagens cuja vida é diretamente atingida pelo fato histórico. A intriga romanesca desenvolvese no campo da realidade histórica. As personagens circulam numa tríade formada pela ética, moral e leis desse período histórico. Jeanie Deans é o contraponto e sua conduta ética expõe as regras da moral e da lei em jogo. Por exemplo, as regras morais dos Puritanos, simbolizadas pelo pai da personagem central, e as dos criminosos, na figura de Madge Wildfire; o funcionamento das leis daquele período, no desenvolvimento do julgamento de Effie, na relação política entre Escócia e Inglaterra e no encontro da personagem com o Duque de Argyle e a Rainha da Inglaterra para pedir o perdão para sua irmã. O que se nota, então, é uma relação de coerência entre a intriga e os dados históricos reais aproveitados no romance.

À vista dessas constatações, entendemos que o objetivo principal do discurso prefacial de Walter Scott é a discussão desse novo tipo de narrativa que se dedica ao entrecruzamento do fato histórico com a ficção. Subjacente à discussão, percebemos a visão histórica de Walter Scott, cujos fundamentos se baseiam nos princípios historiográficos do lluminismo Escocês e no antiquarianismo. Era igualmente importante para o historiador atingir os sentimentos dos leitores para que o passado fosse revivido. Os prefácios têm uma função quase propagandística dessa nova forma de lidar com a representação histórica, havendo, portanto, um diálogo entre Walter Scott e o leitor em uma instância crítica acerca da História; como se fizesse o que Dilthey indica ser a função do conhecimento histórico: "um diálogo entre o historiador em sua vivência (presente) e os outros homens em seu vivido (passado)."75

\footnotetext{
${ }^{74} \mathrm{O}$ título de The Heart of Midlothian refere-se a Tolbooth, antiga prisão de Edimburgo no século XVIII, situada no centro da comarca de Midlothian.

75 Citado por José Carlos Reis. IN: Reis, José Carlos. História \& Teoria.Historicismo, Modernidade,Temporalidade e Verdade. Rio de Janeiro: Editora FGV, 2006, p.117.
} 


\title{
Capítulo II
}

\author{
O discurso prefacial de Balzac: o modelo narrativo scottiano e a história \\ do presente.
}

\author{
1- O realismo balzaquiano: a história do presente
}

\begin{abstract}
Uma das indagações centrais nos textos críticos de Balzac refere-se à relação entre História e romance ${ }^{76} \mathrm{Em}$ seu texto medular sobre seu projeto literário, - Avant-propos da Comédia Humana, Balzac apresenta seu fundamento: "La
\end{abstract} Société française allait être l'historien, je ne devais être que le secrétaire." ${ }^{77}$ A partir desse axioma balzaquiano podemos deduzir uma proposição herdada de Walter Scott: o olhar de historiador do narrador. O vocábulo "secretário" é a chave para que possamos inferir tal conceito. Stéphane Vachon indica a recorrência dos termos historiador, copiador e secretário para designar o romancista, sendo este último evitado por Balzac em seus textos críticos. Vachon nos explica as razões relacionadas à escolha destes termos:

On ne doit pas se laisser abuser par la modestie du terme, ni le rabattre sur une conception étroite du terme réalisme; il convient plutôt de se rappeler que chez Blazac, le roman naît de sa propre dénégation (Le Père Goriot: «ce drame n'est ni fiction, ni un roman», PI., t.III. p.50) et que le réalisme balzacien est intellection, compréhension et interprétation du réel et de la réalité.(...) Évitant le mot «roman», Balzac récuse le mot « romancier», lui préférant le

\footnotetext{
${ }^{76}$ Sobre o teor do discurso prefacial de Balzac, Roland Le Huenen afirma que este se atém a legitimar o romance, e a explicar e justificar seu sentido de composição. No entanto, é possível ainda depreender de seus textos críticos uma reflexão sobre a relação da História e a fatura do romance. Para o crítico: «on posera que si, pour Balzac, le roman s'alimente à l'Histoire, celle-ci ne peut devenir représentable et lisible que par son inscription dans l'économie romanesque, qui deviendrait ainsi le lieu discursif obligé et médiateur hors duquel la voix de la Histoire ne serait pas ou plus audible. Cette perception des rapports du roman et de l'Histoire impliquerait par contrecoup une sémantisation à la fois de l'Histoire et du roman, qu'il s'agit d'expliciter et de problématiser. » Huenen, Roland Le. «Balzac préfacier de l'Histoire. » IN: Mozet, Nicole et Petitier, Paule (éds.). Balzac dans L'Histoire.Paris: SEDES, Collection du Bicentenaire, 2001, p.112: "afirmaremos que, se para Balzac o romance se alimenta da História, esta última somente pode se tornar representável e legível pela sua inscrição na economia romanesca, a qual iria se tornar, dessa maneira, o espaço discursivo obrigatório e mediador, fora do qual a voz da História não seria, ou não seria mais, perceptível. Essa percepção das relações entre o romance e a História implicaria, em contrapartida, uma semantização ao mesmo tempo da História e do romance, o que é preciso explicitar e problematizar."
}

${ }^{77}$ Balzac. "Avant-Propos" de la Comédie Humaine. Écrits Sur Le Roman. Textes choisis, présentés et annotés par Stéphane Vachon. Paris: Le Livre De Poche, 2000, p.287. 
vocable «historien»(...), mais il lui arrive d'employer celui de "sécretaire » - et ce de «copiste » (...) ou de «greffier».(...) II ne faut pas en sous-estimer la portée, que révèle la suite de l'«Avant-propos», et qu'indiquaient, en 1839, la « «Préface» du Caninet des Antiques: «À toutes les époques, les narrateurs ont été les sécretaires de leurs contemporains.» 78

Ao denegar o termo "romancista" e preferir as denominações "secretário", "copista" e "escrivão" em seus textos críticos, Balzac postula de maneira inequívoca a relação do narrador com o referencial histórico. As profissões, listadas por Vachon, possuem um dado comum: a reprodução. A produção final, por elas executada, está subordinada a um agente externo; elas não criam, mas recriam. Sendo assim, quando Balzac se intitula "secretário" acaba por afirmar sua relação com a representação histórica, ou seja, o narrador balzaquiano "reproduzirá" a história da sociedade francesa contemporânea. Se o narrador-historiador scottiano está comprometido com a representação da realidade histórica do passado, 0 narrador balzaquiano empenha-se em representar a realidade histórica do presente. Para bem executar sua função, que seria a transmissão do conhecimento histórico, o "secretário" lança mão de uma habilidade que se torna o apanágio da narrativa balzaquiana: o olhar analítico e descritivo.

Há um paralelo entre esse arranjo da narrativa romanesca com o desejo de representar a história do presente e a afirmação de Lukács, quando diz que Balzac "é o autor que desenvolve da maneira mais consciente a formidável impulsão que o romance recebeu de Scott, criando, dessa forma, o tipo até então desconhecido do romance realista." ${ }^{79} \mathrm{O}$ realismo balzaquino pode ser traduzido, nesse sentido, pelo desejo de reproduzir a história do presente. Nossa questão é esclarecer quais seriam as possíveis implicações desse arranjo na fatura do romance.

\footnotetext{
${ }^{78}$ Balzac. Op. Cit. p.287. Itálico nosso. "Não podemos nos deixar enganar pela modéstia do termo, nem refutá-lo, levando em consideração uma concepção estreita do termo realismo. Faz-se necessário, sobretudo, lembrar que na obra de Balzac o romance nasce de sua própria negação ( $L e$ Père Goriot: "este drama não é ficção, nem um romance", Pl., t.Ill. p.50) e que o realismo balzaquiano é intelecção, compreensão e interpretação do real e da realidade. (...) Evitando a palavra "romance", Balzac recusa a denominação "romancista", sendo-lhe preferível o vocábulo "historiador" (...), mas ele chega a empregar o de "secretário" e o de "copista" (...) ou de "escrivão" (...) Não devemos subestimar o significado que é revelado em seguida no Avant-propos, e que o prefácio do Caninet des Antiques indicava em 1839 ": "Em todas as épocas, os narradores foram os secretários de seus contemporâneos."
}

${ }^{79}$ Lukács, Georg. Op.Cit.p.88. 
Voltamos novamente ao sucinto, porém desafiador parágrafo de Lukács, em que o pensador discute a apropriação do romance de Walter Scott por Balzac. Segundo o teórico, o escritor francês é quem compreende e desenvolve da maneira "mais consciente" o modelo narrativo scottiano. O termo "consciente", empregado por Lukács, estaria relacionado ao pensamento crítico sobre os romances do Waverley Novels ${ }^{80}$, articulado pelo autor francês em seus prefácios e artigos. Nesses textos é muito comum encontrarmos análises literárias muito apuradas, as quais procuram investigar as bases formais e contextuais da correlação entre História e romance. As premissas acerca dessa questão partem quase sempre de Walter Scott, isto é, quando Balzac inicia um raciocínio sobre a construção narrativa, o autor escocês é o ponto de partida. As comparações com a obra de Scott nos permitem identificar os dispositivos narrativos que interessam ao projeto literário de Balzac. O autor da Comédia Humana está ciente de que a história do presente da sociedade francesa resultaria em um novo arranjo narrativo. Desse modo, os romances de Walter Scott não são apenas um “modelo”, aqui pensando em cópia, mas um gênero narrativo que se mostra viável para o conhecimento histórico. É por

${ }^{80}$ É importante assinalar que Balzac não lia os originais dos romances de Walter Scott, mas suas traduções. É o próprio autor que nos informa: "Walter Scott a mille faces, Cooper est un peintre de marine et de paysages, admirablement servi par deux académies, le Sauvage et le Matelot. Sa belle création de Bas-de-Cuir est une œuvre à part. Je ne sais pas l'anglais, je ne puis juger du style de ces deux beaux génies, heuresement pour nous si différents ;mais je crois également l'Écossais bien supérieur à l'Américain dans l'expression de la pensée et dans le mécanisme du style. (...) En resumé, l'un est l'historien de la nature, l'autre de l'humanité." IN: Balzac. "Lettres sur la littérature, le théâtre et les arts". Op. Cit. p.168. Sobre a questão das traduções, vale ressaltar que o mais importante tradutor dos romances de Walter Scott, Auguste Jean-Baptiste Defauconpret, alterava os romances para agradar o gosto conservador do público francês durante a Restauração. $O$ tradutor modificava os romances incorporando elementos góticos, comprometendo as nuances das tensões históricas ao reduzir as dissidências políticas em grandes grupos, numa visão um tanto maniqueísta entre Bem e Mal. Apesar dessas modificações polêmicas no romance, a questão principal que foi apreendida por Balzac, a qual, é discutida em nossa análise, não nos parece ter sido igualmente alterada. A essência do projeto literário scottiano, ou seja, a inclusão do conhecimento histórico na narrativa romanesca continua intacta. O olhar historiográfico presente na composição do narrador scottiano, construído por meio de procedimentos estruturais de representação histórica, constituem um nível narrativo que não era suscetível às mudanças. As alterações de Defauconpret comprometem muito mais o sentido conteudístico, privilegiando uma leitura reducionista do conflito, dificultando o entendimento do intricado conflito político composto por várias facções. No entanto, "a história doméstica", na definição balzaquina, continua presente. A afirmação é válida quando elencamos os comentários sobre os romances de Scott nos prefácios de Balzac. O autor francês indica questões formais e conceituais essenciais em relação à obra de Walter Scott, por exemplo, quando afirma que Walter Scott é um "historiador da humanidade". Esse é um aspecto crucial da narrativa scottiana, que foi desenvolvido posteriormente por críticos da importância de Lukács. Talvez o caráter político tenha sido mais afetado pelas traduções, enquanto que a história social, ou seja, a maneira como a vida humana no nível privado era atingida pelas forças históricas continuava presente na narrativa. Outro aspecto que descarta a possibilidade de uma inadequação analítica, devido aos problemas de tradução, é compreensão balzaquiana dos mecanismos intrínsecos à reprodução histórica que analisaremos mais adiante. 
essa razão que, para a nossa análise, Walter Scott representa nos textos críticos de Balzac um "conceito literário", isto é, seu objeto de estudo.

Walter Scott não é uma "descoberta" de Balzac. Como já havíamos mencionado anteriormente, o escritor escocês era um cânone literário na França do século XIX. A extrema facilidade de aceitação de seus romances, tanto pelo publico leitor quanto pelos escritores, é creditada ao caráter histórico deles, uma vez que a França era um país que vivenciou, como nenhum outro, intensas mudanças históricas em um curto espaço de tempo, como nos esclarece Richard Maxwell:

(...) between the late eighteenth and the late nineteenth century, France was where history happened. We know, or we think we know, that it happened everywhere and that it is omnipresent, but if we think of European or even world history in terms of spectacular and deeply significant events, France was the centre. Its liveliest years would include 1789, 1814, $1830,1848,1870$ e 1871 - in other words, the fall of the Bastille, the fall of Napoleon, the ascension of Louis-Phillipe to the throne, his subsequent fall and fight, the coup d'état of Napoleon III, the Franco-Prussian War, and the brief career of the Commune, bloodily ended by the troops of Adolphe Thiers. If Germany had been the testing ground for history in the seventeenth-century, France was the testing ground for history in the nineteenth. It became, in effect, the theatre of history. ${ }^{81}$

Sob esse aspecto, o que nos parece ser distintivo é o ponto de vista da crítica balzaquiana diante desse cânone literário. Interessa-nos, então, investigar de que maneira o entendimento do autor francês sobre a representação histórica articula-se à estrutura de seu romance realista.

Entretanto, antes de analisarmos os textos críticos, há um trecho do romance Illusions Perdues que merece ser discutido. Trata-se do discurso de Daniel D'Arthez

\footnotetext{
${ }^{81}$ Maxwell, Richard. "Scott in France". IN: Pittock, Murray (ed.). The Reception of Sir Walter Scott in Europe. London: Continuum, 2006. p.13. Itálico do autor: "(...) entre as últimas décadas do século XVIII e XIX, a França foi o lugar onde a história aconteceu. Sabemos, ou achamos que sabemos, que a história aconteceu em todos os lugares e era onipresente, porém se considerarmos a história europeia, ou até mundial, em relação aos acontecimentos espetaculares e profundamente significativos, a França era o centro. Incluiríamos, entre os mais agitados anos, 1789, 1814, 1830, 1848,1870 e 1871. Em outras palavras, a queda da Bastilha, a queda de Napoleão, a ascensão de Louis-Phillipe ao trono, sua queda e luta subsequente, o golpe de estado de Napoleão III, a guerra franco-prussiana, e a breve carreira da Comuna, dissipada de forma sangrenta pelas tropas de Adolphe Thiers. Se a Alemanha havia sido a pista de testes para a história europeia do século XVII, a França foi o laboratório para a história do século XIX. Ela tornou-se, efetivamente, o teatro da história."
} 
ao jovem Lucian de Rubempré, o qual, nesse momento, tenciona tornar-se um romancista.

- Vous êtes dans une belle et bonne voie, répondit gravement le jeune homme; mais votre œuvre est à remanier. Si vous voulez ne pas être le singe de Walter Scott, il faut vous créer une manière différente, et vous l'avez imité. Vous commencez, comme lui, par des longues conversations pour poser vos personnages; quand ils ont causé, vous faites arriver la description et l'action. Cet antagonisme nécessaire à toute œuvre dramatique vient en dernier. Renversez-moi les termes du problème. Remplacez ces diffuses causeries, magnifiques chez Scott, mais sans couleur chez vous, par des descriptions auxquelles se prête si bien notre langue. Que chez vous le dialogue soit la conséquence attendue qui couronne vos préparatifs. Entrez tout d'abord dans l'action. Prenez-moi votre sujet tantôt en travers, tantôt par la queue; enfin variez vos plans, pour n'être jamais le même. Vous serez neuf tout en adaptant à l'histoire de France la forme du drame dialogué de l'Écossais. Walter Scott est sans passions, il l'ignore, ou peut-être lui était-elle interdite par les mœurs hypocrites de son pays. Pour lui, la femme est le devoir incarné. À des rares exceptions près, ses héroïnes sont absolument les mêmes, il n'a eu pour elles qu'un seul poncif, selon expression des peintres. Elles procèdent toutes des Clarisse Harlowe ; en les ramenant toutes à une idée, il ne pouvait que tirer des exemplaires d'un même type variés par un coloriage plus ou moins vif. La femme porte le désordre dans la société par la passion. La passion a des accidents infinis. Peignez donc les passions, vous aurez les ressources immenses dont s'est privé ce grand génie pour être lu dans toutes les familles de la prude Angleterre. En France, vous trouverez les fautes charmantes et les mœurs brillantes du catholicisme à opposer aux sombres figures du calvinisme pendant la période plus passionné de notre histoire. Chaque règne authentique, à partir de Charlemagne, demandera tout au moins un ouvrage, et quelquefois quatre ou cinq, comme pour Louis XIV, Henri IV, François ler. Vous ferez ainsi une histoire de France pittoresque où vous peindrez les costumes, les meubles, les maisons, les intérieurs, la vie privée, tout en donnant l'esprit du temps, au lieu de narrer péniblement des faits connus. ${ }^{82}$

Uma das questões históricas marcantes da sociedade francesa da Restauração, retratada em Illusions Perdues, é o mercantilismo literário. As crenças idealistas de Lucien de Rubempré são "desmistificadas" quando a personagem se insere no torvelinho do cenário literário parisiense. Ali, o jovem ingênuo da província é exposto às regras do mercado literário, sustentadas pelo "ouro e prazer". Porém, nesse romance, e no universo da Comédia Humana, D’Arthez materializa a figura do escritor diletante, desprovido de intenções literárias egocêntricas e capitalistas. Sua fala, dessa maneira, tem uma função metalinguística: é a voz crítica balzaquiana expondo os meandros de seu projeto literário. D’Arthez, ao indicar o caminho que o jovem romancista deve seguir para concluir um romance exemplar, deixa transparecer uma comparação narrativa muito significativa.

${ }^{82}$ Balzac. Illusions Perdues. Paris: Le Livre de Poche, 2006, p.277-278. 
$\mathrm{Na}$ sua preleção, D’Arthez aconselha o jovem escritor a modificar seu romance para que não se transforme no "singe de Walter Scott". Julien, segundo ele, ao escolher a história francesa como objeto para seu romance, está seguindo "um caminho belo e ideal". Entretanto, é preciso que Julien encontre diferentes soluções formais, pois a construção narrativa que privilegia o diálogo é somente eficaz nos romances scottianos. D'Arthez o aconselha a suprimi-lo e substituí-lo pela descrição e pela ação. A substituição de um dispositivo narrativo por outro diz muito do entendimento balzaquiano sobre o gênero narrativo inaugurado por Scott.

O narrador scottiano, que fala a partir do tempo presente sobre um tempo histórico passado, é obrigado a suplantar a distância do tempo vivido delegando às suas personagens o testemunho do passado histórico. A ideia de "reviver" o passado, de fazer com que ele seja "sentido", é possível pelo uso intensivo do diálogo. Em vez de narrar enfadonhamente como era a vida pretérita, Walter Scott faz com que suas personagens materializem aquele tempo. O emprego desse dispositivo narrativo é explicado pelo próprio Scott:

\begin{abstract}
There may be something of system in it however: for we have remarked, that with an attention which amounts even to affectation, he has avoided the common language of narrative, and thrown his story, as much as possible, into a dramatic shape. In many cases he has added greatly to the effect, by keeping both the actors and action continually before the reader, and placing him, in some measure, in the situation of the audience at a theatre, who are compelled to gather the meaning of the scene from what the dramatis personae say to each other, and not from any explanation addressed immediately to themselves. ${ }^{83}$
\end{abstract}

Mesmo que o romance em questão, aqui, seja o de Lucien de Rubempré, é possível traçar um paralelo com a narrativa balzaquiana. $\mathrm{O}$ argumento defendido por D’Arthez diz que é preciso um olhar analítico que investigue a natureza do processo histórico francês para então representá-lo à altura no romance. Segundo a personagem, não seria possível simplesmente "copiar" o romance scottiano, mas ter o domínio, como escritor, do conhecimento histórico, dado essencial da formação do romance do autor escocês.

${ }^{83}$ Scott, Walter. "Review of Tales of My Landlord (1817)". Op. Cit. p.14-15. 
Assim, para a construção narrativa balzaquiana, o uso intensivo do diálogo não faz sentido, uma vez que o narrador balzaquiano é testemunha do processo histórico. Quando Balzac escolhe representar a história do presente, ocorre uma mudança no foco narrativo, ou no ponto de vista do narrador, este último poderá, no caso balzaquiano, ser a testemunha ocular da História. Assim, descrição e ação passam ao primeiro plano, pois quem guia os olhos do leitor no "teatro" histórico da Restauração francesa é um narrador que, além de possuir um olhar de historiador, vivencia o momento histórico que está narrando.

A consciência sobre a diferença entre o passado histórico e o presente histórico no plano narrativo vai sendo articulada e desenvolvida ao longo dos textos críticos de Balzac. Segundo Roland Le Huenen ${ }^{84}$, a discussão especializada sobre a narrativa romanesca inicia-se em 1828 com o prefácio ao romance Les Chouans, intitulado "L'Avertissement du Gars", e é concluída com a publicação do Avantpropos em 1842, data da publicação da Comédia Humana. Em nosso estudo incluímos um texto anterior a 1828, uma vez que nosso foco é a presença de Walter Scott nos textos críticos de Balzac, direção analítica que nos obriga a investigar outros textos críticos além dos prefácios. Sendo assim, a discussão sobre a narrativa scottiana inicia-se em 1824, com a publicação de um artigo crítico sobre o romance St. Ronan's Well.

O artigo de 1824, publicado no Feuilleton Littéraire, trata do único romance St. Ronan's Well - em que o autor escocês afasta-se do passado e se dedica ao presente, pretendendo "celebrare domestica facta - to give imitation of the shifting manners of our own time" ${ }^{\prime 85}$. A discussão sobre a representação histórica nesse artigo diz respeito ao presente. Balzac identifica alguns problemas referentes à tentativa de Scott de reproduzir a história do presente. As falhas do romance scottiano acabam sugerindo a Balzac quais seriam os dispositivos narrativos mais adequados à representação desse tempo histórico.

\footnotetext{
${ }^{84}$ Huenen, Roland Le. « Balzac préfacier de l'Histoire. » Op. Cit. p.112.

${ }^{85}$ The Prefaces to the Waverley Novels by Sir Walter Scott edited by Mark A. Weinstein. Lincoln and London: University of Nebraska Press, 1978, p.200.
} 
No Avant-propos, Balzac questiona: "Mais comment rendre intéressant le drame à trois et quattre mille personnages que présente cette Société?" ${ }^{86}$ - Balzac está fazendo alusão, nessa passagem, à sociedade da Restauração. O desejo do autor é ousado, pois a representação histórica do presente é, a princípio, quase impossível, se levarmos em consideração seu caráter mutável. De que maneira, então, representar historicamente o devir? Na verdade, o questionamento de Balzac não é apenas uma pergunta retórica, mas a força motriz da Comédia Humana.

A ideia de representar a história do presente mostrou-se viável devido à escolha realizada por Balzac. O tempo histórico circunscrito na Comédia Humana compreende apenas um período revolucionário da história francesa: a Restauração (1814-1830). O interessante é que esse período é tratado como o único acontecimento histórico de fundo nos romances; passado e futuro são abordados a partir dessa perspectiva, arquitetando a dimensão histórica do presente. $O$ sentido extraído dessa experiência histórica é construído a partir das observações do narrador que nos descreve a materialidade daquele tempo. Contrariamente, o projeto literário de Scott não é uma composição única, mas múltipla. O autor escocês não se prende a um único momento histórico, ele quer, em vez disso, retratar diferentes períodos e, consequentemente, múltiplos eventos históricos que constituem o passado histórico da Escócia. Walter Scott respeita a ordem cronológica histórica clássica: passado, presente, futuro. Balzac, por sua vez, desestrutura essa ordem, criando uma cronologia muito particular: passado no presente, presente, presente sem futuro.

Contudo, a construção do tempo histórico na narrativa balzaquiana não é um entendimento prévio à realização de seu projeto, como de fato fica confirmado no primeiro romance da Comédia Humana, Les Chouans, que ainda segue a ordem histórica clássica. O que se nota nos textos críticos de Balzac é uma análise progressiva da construção romanesca do presente histórico. O primeiro insight sobre essa questão aparece na crítica sobre St. Ronan's Well, quando Balzac acaba

\footnotetext{
${ }^{86}$ Balzac. "Avant-Propos" de la Comédie Humaine. Écrits Sur Le Roman. Textes choisis, présentés et annotés par Stéphane Vachon. Paris: Le Livre De Poche, 2000, p.300.
} 
entrevendo a "grandeza" da ideia de fundamentar o conhecimento histórico do presente na narrativa romanesca.

O balanço geral da crítica balzaquiana sobre esse romance de Scott em particular é negativo. Entretanto, as falhas do romance scottiano, como já mencionamos, iluminam Balzac sobre os procedimentos para a representação do presente histórico:

Cette idée était grande sans doute; mais rien de plus étroit que le cadre choisi pour la développer. C'est dans un petit village dont la célébrité nous est encore inconnue que l'auteur établi le siège de l'action, et fait mouvoir les héros de son drame. ${ }^{87}$

Segundo a análise balzaquiana, a escolha do espaço é problemática, pois não há, verdadeiramente, uma relação entre o espaço de St. Ronan's Well e a História do presente. Se o objetivo de Scott é representar historicamente "a Escócia do começo do século XIX" ${ }^{88}$, o resultado não é satisfatório. Para Balzac, não haveria nenhum problema em situar um romance que pretenda apenas retratar os hábitos de uma época, ou as mazelas individuais, em um vilarejo qualquer. Entretanto, se o propósito é a representação histórica de uma época, tal escolha é inadequada. A cidade em que se passa a trama ${ }^{89}$ é fictícia, além disso, nada ali diz respeito às tensões históricas que normalmente estão presentes nos romances de Scott. St. Ronan's Well é apenas uma estância turística, onde as personagens buscam o lazer. De maneira que a "estreiteza" do quadro scottiano, no entendimento de Balzac, refere-se à falta de relação entre a cidade e o momento histórico da Escócia. Para falar das tensões históricas do presente não deveria um autor olhar para as grandes capitais? Não resultaria a escolha de uma cidade fictícia em um prejuízo do conhecimento histórico, uma desconexão com o referencial histórico? Essa é a "estreiteza" da escolha scottiana em relação ao presente. Sem o

\footnotetext{
${ }^{87}$ Balzac. "Avant-Propos" de la Comédie Humaine.Op.Cit.p.43.

${ }^{88}$ Idem, Ibidem, p.43.

${ }^{89}$ O título do romance é o nome de uma estância turística fictícia, onde figuras da alta sociedade se refugiam à procura de lazer e repouso. Neste quadro, o romance trata da disputa de dois meioirmãos Valentine Bulmer e Francis Tyrrel, filhos do Conde de Etherington, sendo somente Valentine considerado seu filho legítimo. O romance se desenvolve em torno das desavenças entre os irmãos, agravadas pela ambição de Valentine, sempre em busca de fortuna e prestígio.
} 
referencial real, o espaço torna-se anistórico. Com essa ideia em mente, Balzac se dá conta de que Paris é o espaço histórico do universo da Comédia Humana. Mesmo que alguns romances se passem na província, há sempre um paralelo com a grande capital, símbolo da história da Restauração.

Paris passará a ser o contexto ideal para o desenvolvimento de sua "epopeia" burguesa, uma vez que viabiliza a concentração de tempo e espaço necessários à narrativa da História do presente. Ademais, suas características e constantes mudanças no plano cotidiano estão em sintonia com o tempo do devir. A crítica Paule Petitier afirma a importância de Paris na obra balzaquiana sugerindo que a Comédia Humana é uma epopeia de "fait-Paris", em um jogo de palavras com a expressão jornalística francesa "fait-divers". Balzac evidencia o caráter emblemático de Paris no capítulo introdutório ${ }^{90}$ do romance La fille aux yeux d'or:

\begin{abstract}
Paris est la tête du globe, un cerveau qui crève de génie et conduit la civilization humaine, un grand homme, un artiste incessamment créateur, un politique à seconde vue qui doit nécessairement avoir les rides du cerveau, les vices du grand homme, les fantasies de l'artiste e les blasements du politique. Sa physionomie sous-entend la germination du bien et du mal, le combat et la victoire ; la bataille morale de 89 dont les trompettes retentissent encore dans tous les coins du monde ; et aussi l'abattement de $1814 .^{91}$
\end{abstract}

Nesse trecho, a capital francesa aparece como o centro do mundo, um resquício cultural herdado do período napoleônico. Afirmação grandiloquente sem dúvida, mas sensata, se levarmos em conta a importância histórica da cidade no século XIX. Paris foi, de fato, palco das grandes revoluções ocorridas no século XIX, em uma vertiginosa sucessão de disputas políticas que abrangem o período de 1770 a 1880. A despeito do nacionalismo latente, a cidade é entendida, metonimicamente, como a própria revolução, contendo todos os elementos revolucionários. Ela é o "cérebro que excede em inteligência e conduz a civilização humana", é "um grande homem", "um artista", "um político", em suma, a Paris descrita acima é o resultado, no presente, do processo histórico. Primeiramente, a

\footnotetext{
${ }^{90}$ O início do primeiro capítulo do romance La fille aux yeux d’or funciona como uma espécie de prefácio introdutório, quase independente da narrativa. Somente nas páginas finais encontramos algum vínculo com a história a ser narrada; mesmo assim, a narrativa inicia-se subitamente. Na parte introdutória a voz do narrador aproxima-se mais do discurso prefacial, não sendo incomum comparála à voz do narrador do Avant-propos.
}

${ }^{91}$ Balzac. La fille aux yeux d'or. IN: Histoire des Treize. Paris: Pocket, 1992, p. 354-355. 
"batalha moral de 1789", que testemunha a profunda mudança na ordem social (Balzac refere-se à Revolução Francesa como "batalha moral", uma vez que após esse período verifica-se uma nova experiência humana e social). Em seguida, "o abatimento de 1814", que corresponde ao início da Restauração, momento que Louis XVIII sobe ao trono, e a França presencia, novamente, uma reestruturação sócio-política e econômica, com o regresso à monarquia e o fortalecimento do capitalismo.

O romance La Fille aux yeux d'or foi publicado entre 1833 e 1835, juntamente com outros dois (Ferragus e La Duchesse de Langeais), formando uma trilogia intitulada Histoire des Treize. Concretamente, não existe uma conexão entre eles, salvo a ideia de que o heroi principal, de cada um, pertence a uma sociedade secreta. No entanto, os três apresentam uma tensão entre os velhos hábitos sociais aristocráticos e a nova ordem social capitalista, vivenciada em toda sua assustadora novidade. O que de fato os conecta é a vida pulsante de Paris.

Nesse sentido, o "capítulo-prefácio" de La Fille aux yeux d'or pode ser entendido como uma extensão do artigo dedicado ao romance de Walter Scott, St. Ronan's Well, e um complemento do Avant-propos, especialmente quando Balzac afirma ser necessário encontrar o "moteur social""2 do processo histórico do presente. Paris é, nesse contexto, o "motor social" da Comédia Humana, símbolo das mudanças impostas pelo capitalismo, e a razão do movimento social, como afirma Hobsbawm:

A frase "quando os bons americanos morrem, eles vão para Paris" expressa aquilo em que
Paris se transformou no século XIX, embora só tenha se tornado plenamente o paraíso dos
parvenus no Segundo Império. Londres ou, mais ainda, Viena, São Petersburgo ou Berlim
eram capitais em que o dinheiro ainda não podia comprar tudo, ao menos, na primeira

92 “Ce travail n'était rien encore. S'en tenant à cette reproduction rigoureuse, un écrivain pouvait devenir un peintre plus ou moins fidèle, plus ou moins heureux, patient ou courageux des types humains, le conteur des drames de la vie intime, l'archéologue du mobilier social, le nomanclateur des professions, l'enregistreur du bien et du mal ; mais, pour mériter les éloges que doit ambitionner tout artiste, ne devais-je pas étudier les raisons ou la raison de ces effects sociaux, surprendre le sens caché dans cet immense assemblage de figures, de passions et d'événements. Enfin, après avoir cherché, je ne dis pas trouvé, cette raison, ce moteur social, ne fallait-il pas méditer sur les principes naturels et voir en quoi les Sociétés s'écartent ou se rapprochent de la règle éternelle, du vrai, du beau ? Malgré l'étendue des prémisses, qui pouvaint être à elles seules un ouvrage, l'œuvre, pour être entière, voulait une conclusion. Ainsi dépeinte, la Société devait porter avec elle la raison de son mouvement". Balzac. Avant-propos. Op. Cit. p. 288-289. 
geração. Em Paris, havia pouca coisa que valesse a pena comprar que não estivesse ao seu alcance. ${ }^{93}$

Paris (símbolo da nova ordem sócio-política da sociedade francesa) é um espetáculo de horrores:

Un des spectacles où se rencontrent le plus d'épouvantement est certes l'aspect général de la population parisienne, peuple horrible à voir, hâve, jaune, tanné. Paris n'est-il pas un vaste champ incessamment remué par une tempête d'intérêts sous laquelle tourbillone une moisson d'hommes que la mort fauche plus souvent qu'ailleurs et qui renaissent toujours aussi serrés, dont les visages contournés, tordus, rendent par tous les pores l'esprit, les désirs, les poisons dont sont engrossés leurs cerveaux ; non pas des visages, mais bien des masques: masques de faiblesse, masques de force, masques de misère, masques de joie, masques d'hypocrisie; tous exténués, tous empreints des signes ineffaçables d'une haletante avidité? Que veulent-ils ? De l'or, ou de plaisir?

Quelque observations sur l'âme de Paris peuvent expliquer les causes de sa physionommie cadavéreuse qui n'a que deux âges, ou la jeunesse ou la caducité : jeunesse blafarde et sans couleur, caducité fardée qui veut paraître jeune. ${ }^{94}$

Balzac descreve a vida parisiense como um espetáculo infernal do desenvolvimento capitalista, visão construída com a ajuda de vocábulos como: "épouvantement”, "horrible”, "tempête”, “cadavéreuse" (terror, horrível, tempestade, cadavérico). O presente balzaquiano é, pois, sem futuro. A visão balzaquiana do presente histórico, diante da complexidade da nova ordem social, é temerária e marcada pelo pessimismo. Tudo na cidade, espaço que concretiza o processo histórico, lembra o fim, a morte, ou mesmo que haja um futuro, este não é em nada diferente desse momento infernal: "Paris é um vasto campo incessantemente agitado por uma tempestade de interesses sob a qual circula uma safra de homens, que a morte ceifa com mais frequência do que em outro lugar, e que renascem igualmente oprimidos." Quem apreende o espírito desse tempo histórico, ou "a alma de Paris", é o narrador-historiador. Sua observação dos detalhes, do que existe atrás das máscaras, permite-Ihe retratar o momento sócio-histórico, ou a "fisionomia cadavérica" da Restauração, idade do "ouro e do prazer."

A experiência histórica comum do presente, e que é base da intriga de muitos romances da Comédia Humana, é pautada pelo desejo de enriquecimento e pela satisfação, ou seja, o desejo do "ouro e do prazer". Esses dois valores

\footnotetext{
${ }^{93}$ Hobsbawm, Eric. Op. Cit. p.184.

${ }^{94}$ Balzac. La fille aux yeux d'or. IN: Histoire des Treize. Paris: Pocket, 1992, p.339.
} 
representam, respectivamente, os eixos da sociedade capitalista e do Antigo Regime. Passado e presente coexistem na dimensão temporal balzaquiana, e, por esse motivo, a Restauração "tem somente duas idades, ou a juventude ou a caducidade". O período pós-revolucionário da Restauração não havia de forma alguma exterminado com os antigos padrões aristocráticos ${ }^{95}$, ao contrário, a antiga organização sócio-cultural era assimilada pela nova ordem social. Um dos valores da sociedade francesa do século XVIII residia no prazer ${ }^{96}$, traço marcante da "libertinagem de costumes" que vigorava nessa época. O ouro, por sua vez, é o símbolo absoluto da era capitalista. A aliança entre o ouro e o prazer nada mais é que a coexistência dos valores passados e presentes.

A descrição do quadro infernal e caótico do presente histórico continua e, em dado momento, o narrador-historiador alerta:

L'or et plaisir. Prenez ces deux mots comme une lumière et parcourez cette grande cage de plâtre, cette ruche à ruisseaux noirs, et suivez-y les serpenteaux de cette pensée qui l'agite, la soulève, la travaille. Voyez. Examinez d'abord le monde qui n'a rien. ${ }^{97}$

"Ouro e prazer. Considere essas duas palavras como uma luz": o aviso está dado ao leitor. A Comédia Humana é uma reflexão da história do presente, e para seguir "os caminhos dessa reflexão que movimenta, estrutura e compõe" esse grande projeto literário é preciso entender o fundamento do presente histórico, resumido por Balzac pelo binômio ouro e prazer.

\footnotetext{
${ }^{95}$ A esse respeito Hobsbawm afirma: "Além do mais, uma cultura tão profundamente formada pela corte e pela aristocracia como a francesa, não perderia a estampa. (...) De fato, a Revolução preservou de muitas maneiras as características aristocráticas da cultura francesa de forma excepcionalmente pura, pela mesma razão que a Revolução Russa preservou, com excepcional fidelidade, o bale clássico e a típica mentalidade burguesa do século XIX em relação à "boa literatura". Estas características foram tomadas e assimiladas como uma herança desejável do passado, e daí em diante protegidas contra a erosão evolutiva normal." IN: Hobsbawm, Eric. Op. Cit. p.183.

${ }^{96}$ Segundo Sergio Paulo Rouanet, na sociedade aristocrática do século XVIII "os assuntos de Estado eram temas de especialistas, versados em coisas esotéricas como economia política e economia. Não interessavam ao "monde" - eram, portanto, um assunto privado. O que era público era o amor, o comentário amoroso, a informação sobre quem estava dormindo com quem. O próprio amor era socializado pela orgia. (...) Toda esta vida dedicada desvairadamente ao prazer era criticada pelos romances libertinos." IN: Novaes, Adauto. O desejo. São Paulo: Companhia da Letras, 1999, p.171.
}

${ }^{97}$ Balzac. La fille aux yeux d'or. Op.Cit. p. 341. 
Pensando na história do presente, uma cidade fictícia como St. Ronan's Well, se comparada a Paris, não impressiona. Balzac, de certa maneira, decepciona-se com o romance de Walter Scott, pois, contrariamente aos outros romances que são sempre "tão ricos em cores verdadeiras e variadas", St. Ronan's Well é "pálido e monótono." ${ }^{98} \mathrm{O}$ autor francês não encontra nesse romance aquilo que mais aprecia em Walter Scott, ou seja, a fusão entre História e ficção:

Aucun personnage historique ne figure dans ce roman; les caractères sont de fantasie ; la donné est purement idéale: seulement quelques détails de localité rappellent de temps en temps la manière de l'auter; mais cela ne suffit pas, selon nous, pour justifier le titre de roman historique q'usurpent Les Eaux de Saint-Ronan. ${ }^{99}$

Há, nesse trecho da análise balzaquiana, uma informação importante sobre a sua narrativa romanesca. Segundo Balzac, a base de um romance não é "um dado puramente ideal", isto é, o romance não é inteiramente fruto da imaginação, ele necessita de um referencial da realidade histórica. Sendo assim, o romance de Walter Scott falha, visto que o narrador-historiador, incapaz de observar a realidade histórica do presente, isola a trama do romance do processo histórico. A conclusão de Balzac é que Walter Scott "não está à vontade em relação ao seu século."100 A inferência é compartilhada pelo próprio Walter Scott:

It is not, however, sufficient that a mine be in itself rich and easily accessible; it is necessary that the engineer who explores it should himself, in a mining phrase, have an accurate knowledge of the "country", and possess the skill necessary to work it to advantage. In this respect, the Author of St. Ronan's Well could not be termed fortunate. His habits of life had not led him much, of late years at least, into its general or bustling scenes, nor had he mingled often into society which enables the observer to "shoot folly as it flies". The consequence perhaps was, that the characters wanted that force and precision which can only be given by a writer who is familiarly acquainted with his subject. ${ }^{101}$

O olhar do narrador scottiano é confundido pela realidade histórica desse presente desconhecido. Para Walter Scott, explorar o presente demanda um conhecimento técnico, especializado. É curioso que a "divining rod" de Walter Scott

\footnotetext{
${ }^{98}$ Balzac. "Les Eaux de Saint-Ronan, par Sir Walter Scott." Écrits Sur Le Roman. Textes choisis, présentés et annotés par Stéphane Vachon. Paris: Le Livre De Poche, 2000, p.46.

${ }^{99}$ Idem, Ibidem, p.42.

${ }^{100}$ Idem, Ibidem, p.46.

101 Scott, Walter. "St. Ronan's Well". The Prefaces to the Waverley Novels by Sir Walter Scott edited by Mark A. Weinstein. Lincoln and London: University of Nebraska Press, 1978, p. 203.
} 
não é apta para vasculhar a história do presente. O autor escocês declara não ser suficientemente equipado para explorar tal realidade, concluindo que, se deve haver uma consonância entre o ponto de vista do narrador e o tempo da vida prosaica, para que a realidade histórica imanente à vida seja apreendida, seu romance sobre o presente é falho nesse aspecto. Balzac, por outro lado, é o autor que, imbuído desse espírito técnico, irá explorar a "mina", isto é, a representação da história social do presente, caminho iniciado por Scott.

Os textos críticos de Balzac apresentam uma reflexão incessante sobre essa questão. As soluções serão encontradas ao longo de seus textos, sobretudo, os prefácios. Como afirma Roland Le Huenen, o discurso prefacial balzaquiano é um convite a "refletir sobre os procedimentos de representação próprios da ficção, em relação ao referencial histórico". ${ }^{102}$ O componente deflagrador dessa reflexão - o qual não é mencionado pelo crítico - é o projeto literário de Walter Scott de incorporar o conhecimento histórico no romance.

Seguindo a trajetória da construção teórica de Balzac acerca da representação histórica na narrativa romanesca, notamos uma espécie de entreato entre a constatação sobre a engenhosidade de se representar historicamente o presente e a publicação dos romances que se dedicam efetivamente a esse empreendimento literário. Nesse entreato criativo, Balzac publica Les Chouans em 1829 - primeiro romance sob sua assinatura. Até essa data, o autor havia publicado alguns romances sob diferentes pseudônimos. ${ }^{103}$ Sobre o "salto" de um modelo narrativo a outro, o crítico José-Luiz Diaz afirma:

\footnotetext{
102 "(...) réfléchir sur les procédures de répresentation propres à la fiction, en regard du référent historique." Huenen,Roland Le. "Balzac préfacier de l'Histoire". IN: Mozet, Nicole et Petitier, Paule (éds.). Op.Cit. p.116.

${ }^{103}$ Ver o capítulo "CEuvres de Jeneusse" do livro de H.J.Garnand. Nesse capítulo, Garnand analisa os romances de juventude de Balzac, realizando um levantamento dos procedimentos formais que Balzac utiliza à maneira de Walter Scott. Para Garnand, nessa fase inicial, Walter Scott é realmente um "modelo" para o jovem escritor. Entre as obras, o autor destaca: L'Héritière de Birague, JeanLouis, L'Israélite, Le Centenaire, Les Vicaires des Ardennes, La Dernière Fée, Argow le Pirate, Jane La Pale, L'Excommunié e Dom Gigadas. A autoria dessas obras é atribuída a A. de Viellerglé, Lord R'hoone, e Horace de Saint-Aubin. IN: Garnand, H.J. The Influence of Walter Scott on the Works of Balzac. New York: Octagon Books, 1971.
} 
Nous avons peu de documents pour comprendre cet événement majeur qu'a dû être, pour l'auteur du Dernier Choaun, ou la Bretagne en 1800 (mars 1829) devenant tout aussitôt l'auteur des Scènes de la vie privée (avril 1830), ce retournement génial par lequel, quittant le cadre walterscottien de l'Histoire de France pittoresque dans lequel se mouvait encore le non-viable auteur de Gars, Victor Morillon, désireux de « déssiner les immenses détails de la vie des siècles", il (Balzac) a eu l'idée excitante de faire coïncider son exigence d'intelligibilité historique et son souci de rendre compte, de manière passionée, d'une " actualité » devenue soudain mouvante et incommensurable, et cela dès avant la révolution de Juillet. ${ }^{104}$

Nossa hipótese, em relação à falta de documentos que indiquem essa mudança na Comédia Humana, é o artigo de Balzac sobre o romance St. Ronan's Well, publicado em 1824. Como vimos, a falta de sucesso da empreitada scottiana em relação à representação do presente histórico sugeriu a Balzac a estrutura de seu projeto literário sobre a história do presente. De fato, se analisarmos o prefácio de Les Chouans em relação aos outros prefácios fica evidente essa reviravolta, de que fala José-Luiz Dias, nos romances posteriores da Comédia Humana, os quais tratarão inequivocamente do presente histórico. Se descartarmos o artigo publicado em 1824 e o desenvolvimento do pensamento crítico balzaquiano em relação à obra de Walter Scott, ficamos realmente sem saber o que o teria levado a mudar a natureza de sua narrativa.

O prefácio do romance Les Chouans é curioso. Nele, Balzac inicia a discussão opondo-se radicalmente à estratégia empregada por Walter Scott em seus prefácios originais:

\begin{abstract}
Nous sommes hereux de pouvoir avouer que notre sentiment a été partagé par l'auteur de cet ouvrage - il manifesta toujours une aversion profonde pour ces préfaces semblables à des parades, où l'on s'efforce de faire croire à l'existence d'abbés, de militaires, des sacristains, de gens morts dans les cachots, et à des trouvailles de manuscrits, qui font épancher sur des créatures postiches tous les trésors de la sympathie. Sir Walter Scott a eu cette manie, mais il a eu le bon esprit de se moquer lui-même de ces superfétations qui ôtent de vérité à un livre. ${ }^{105}$
\end{abstract}

104 Diaz, José-Luiz. "Saisir le Siècle". IN: Mozet, Nicole et Petitier, Paule (éds.). Op.Cit.p.268: "Temos
poucos documentos para compreender esse importante acontecimento que deve ter sido, para o
autor do Dernier Chouan, ou la Bretagne en 1800 (março 1829), para que este se tornasse logo em
seguida o autor de Scènes de la vie privée (abril 1830); essa reviravolta genial pela qual,
abandonando o quadro scottiano de l'Histoire de France pittoresque, no qual ainda se movia o
inviável autor de Gars, Victor Morillon, desejoso de "retratar os imensos detalhes da vida dos
séculos", Balzac teve a excitante ideia de fazer coincidir sua exigência de inteligibilidade histórica e
sua preocupação de apreender, de maneira apaixonada, uma "atualidade" que se tornou,
repentinamente, mutável e incompreensível, e isto desde antes da revolução de Julho."

${ }^{105}$ Balzac. "Avertissement du Gars." Op. Cit. p.49-50. 
Após desaprovação tão franca, era de se esperar que o autor desenvolvesse seu discurso prefacial sem tais artefatos. No entanto, o prefácio pretende ser a reprodução de uma carta de $\mathrm{M}$. Victor Morillon, "autor" do romance, contando detalhes sobre sua vida e pensamento. A contradição é emblemática, Balzac parece estar entre dois mundos fictícios: o seu e o scottiano; não há ainda uma articulação narrativa concreta em torno do presente histórico; na definição de José-Luiz Diaz, o "autor" fictício, Victor Morillon, não é viável, ele é um híbrido.

Balzac reconhecia que Walter Scott empregava esses artifícios em seus prefácios para ilustrar sua concepção teórica sobre a representação histórica, porém o autor francês parece não ter formulado em definitivo sua própria teoria, ou melhor, sua própria construção narrativa sem ser o "singe" de Walter Scott. Temos a impressão de que a preleção de D'Arthez, realizada muito posteriormente, descreve a sua própria experiência sobre a narrativa romanesca. Nesse momento, ainda existem hesitações: se não há mais a necessidade de recorrer aos manuscritos e ao jogo autoral, ainda é preciso entender essa construção narrativa, que entrecruza História e imaginação. Sem saber concretizar sua visão a esse respeito, a figura de um romancista que incorpora sonho e observação da realidade é uma solução. $A$ biografia de M. Victor Morillon, desenvolvida no prefácio, é na verdade um símbolo da própria narrativa romanesca. Quanto acontece de o "autor" ter em mãos um romance de Walter Scott, é a oportunidade de "revelar os segredos", ou seja, os procedimentos desse gênero narrativo:

\footnotetext{
Un roman de sir Walter Scott tomba entre les mains de M. Victor Morillon, et il demeura ravi de cette composition dans le secret de laquelle il était pleinement entré. II assura avoir vu plus d'une fois des hommes aussi quelquefois plus curieux que Wamba et Gurth, Daddy Rat et Caleb et connaître si familièrement les temps et les mœurs du Moyen Âge, qu'il raconta le soir même où il finit de lire l'ouvrage, une histoire dans laquelle il encadra le duc de Bourgogne et le roi Charles VI avec tant de vérité que M. Buet resta frappé d'un nouvel étonnement. ${ }^{106}$
}

Finalmente, quando Victor Morillon afirma que "a história torna-se doméstica sob seus pincéis", encontramos, aí, formulada a importante contribuição de Walter Scott para a formação do romance balzaquiano. A "história doméstica", referida por

\footnotetext{
${ }^{106}$ Balzac. "Avertissement du Gars." Op. Cit. p. 61.
} 
Balzac, nada mais é do que sua definição para a história social, que será analisada com mais cuidado e excelência nos textos críticos que se sucedem.

Quant à moi, messieurs, je ne prétends attaquer en aucune manière sir Walter Scott. C'est pour moi un homme de génie, il connaît le cœur humain, et s'il manque à sa lyre les cordes sur lesquelles on peut chanter l'amour qu'il nous présente tout venu et qu'il ne montre jamais naissant et grandissant, l'histoire devient doméstique sous ses pinceaux ; après l'avoir lu, on comprend mieux un siècle, il en évoque l'esprit et dans une seule scène en exprime le génie et la physionomie. ${ }^{107}$

Walter Scott tem um papel preponderante na reflexão crítica balzaquiana, pois fundamenta o conceito sobre a representação do mundo, no campo ficcional, por meio da História. Em seus textos críticos, o autor da Comédia Humana está em constante debate com esse conceito que alimenta a formação de seu projeto literário, formulando, nos textos posteriores, os princípios teóricos da representação histórica do presente. Tais princípios são estruturados com base nos procedimentos considerados imprescindíveis e divergentes para a realização de seu projeto. Evidentemente, é dos romances de Walter Scott que provêem os exemplos para o cotejo desses procedimentos.

Nesse sentido, a leitura crítica que Balzac faz das obras de Walter Scott é extremamente eficaz, pois, além do conceito, compreende quais são os procedimentos, ou "mecanismo", termo empregado pelos autores, de representação histórica na narrativa romanesca. É singular como os autores, em seus textos críticos, desenvolvem um conceito de mecanismo atuante na narrativa romanesca, cuja função é tornar possível a representação histórica. Walter Scott usualmente emprega o termo "machinery" e Balzac, "mécanisme". A construção do mecanismo seria pautada pelo tempo histórico. Sendo assim, alguns procedimentos envolvidos no mecanismo de representação devem ser alterados conforme a perspectiva temporal.

Balzac, em seus textos críticos, dedica-se à análise desse mecanismo, desmontando suas peças, investigando seu funcionamento, diagnosticando suas falhas - relativas ao seu desejo de representar historicamente o presente - para

${ }^{107}$ Balzac. "Avertissement du Gars." Op. Cit. p.63. Itálicos nossos. 
então, construir o seu próprio. Nesse contexto, o Avant-propos figura o mecanismo pronto, mas para bem avaliá-lo é preciso acompanhar o processo analítico que culminou nesse texto-síntese.

2- A visibilidade da história do presente: o mosaico balzaquiano.

Como já mencionamos, a visão histórica balzaquiana não segue os passos da Clio clássica. A História oficial, dos grandes acontecimentos, não lhe interessava. O que lhe interessa é a "história doméstica" que havia sido desenvolvida por Walter Scott. Sendo assim, Balzac, ao longo de seus prefácios, compreende que alguns procedimentos narrativos são indispensáveis para o "mecanismo" de representação da história social:

Le roman, pour arriver à une place honorable dans la littérature, doit être en effet histoire des mœurs, dont ne se soucient guère les historiens en toges qui se croient grands pour avoir enregistrés de faits. Sous ce rapport, M. de Balzac est un historien qui restera. Qu'importe qui le vrai qu'il explicite semble d'abord petit, comparé aux faux grandiose de tant de livres contemporains, si l'ensemble doit faire une masse imposante! Mais cette critique, relative aux détails, nous semble injuste encore. M. de Balzac a compris (...) qu'en dehors des grands types et des passions majeures, renouvelées sous tant des faces, il existe des types secondaires et des passions de moyen ordre, non moins dramatiques, et surtout plus neufs. Ces passions et ces types, il est allé les chercher presque tous dans la famille, autour du foyer; et fouillant sous ces envellopes en apparence si uniformes et si calmes, il en a exhumé tout à coup des caratères tellement multiples et naturels em même temps, que tout le monde s'est demandé comment des choses aussi familières, aussi vraies, étaient restées si longtemps inconnues. (...) Ce romancier entreprend pour la société actuelle ce que Walter Scott a fait pour le Moyen Âge. L'un a résumé en types larges et saillants tous les caractères généraux des grandes époques historiques de l'Angleterre et de l'Écosse: hommes et femmes, corporations et castes, partis, sectes, courtisans, bourgeois, princes, manants, il a tout fait poser devant lui, tout classé, tout mis en relief. L'œuvre de M. de Balzac, plus logiquement disposée, non moins grandiose, n'était pas moins difficile, et n'est pas moins merveilleusement exécutée. À travers toutes les physionomies pâles et effacées de la noblesse, de la bourgeoisie et du peuple de notre époque, il choisit ces traits fugitifs, ces nuances délicates, ces finesses imperceptibles aux yeux vulgaires; il creuse ces habitudes, anatomise ces gestes, scrute ces regards, ces inflexions de voix et de visage qui ne se disaient rien ou disaient quelque chose à tous, et sa galerie de portraits se déroule féconde, inépuisable, toujours plus complète (...). ${ }^{108}$

Desse trecho, destacamos dois procedimentos cruciais para a representação histórica: o escrutínio da vida cotidiana e o retrato dos tipos sociais. A novidade desses procedimentos na obra de Balzac, percebida pelos leitores, os quais se

\footnotetext{
${ }^{108}$ Balzac. "Introduction" aux Études philosophiques. Op. Cit. p.100-101.
} 
perguntam como coisas tão prosaicas haviam ficado tanto tempo desconhecidas, refere-se à escolha do tempo histórico. No entanto, o mecanismo desses procedimentos já havia sido desenvolvido por Walter Scott. O verbo "fouiller" (vasculhar), empregado por Balzac, para designar a tarefa do narrador-historiador, remete-nos imediatamente à metáfora scottiana da "divining-rod". Essa correlação refere-se a uma característica comum e essencial para a narrativa dos dois autores, ou seja, a visibilidade. Há uma preocupação em construir uma narrativa que permita ao leitor visualizar a história, para compreendê-la e também senti-la. A "divining-rod" e o verbo "fouiller" trazem à tona os detalhes do vivido histórico: a linguagem, o vestuário, os sabores, as manias, os cheiros, as crenças, os meios de transporte, a fabricação dos objetos, a atuação dos profissionais, etc. Em relação a esta última, basta lembrarmo-nos dos vários tipos de profissionais - e a descrição minuciosa realizada pelo narrador de sua rotina - que povoam a Comédia Humana. Um bom exemplo, no plano narrativo, da visibilidade da "história doméstica" é o início dos romances The Heart of Midlothian e Illusions Perdues. Ambos iniciam com uma descrição detalhada, técnica, sobre um dado material do modo de vida retratado. O interessante é que as descrições são importantes para a intriga romanesca, elas formam um sentido coerente com o universo do romance.

Em The Hearth of Midlothian, o narrador explica-nos a dificuldade de locomoção no interior da Grã-Bretanha, devido à precariedade dos veículos. Gastava-se muito tempo se deslocando de um lugar a outro, ademais, a viagem nunca era livre de incidentes:

\footnotetext{
The times have changed in nothing more (we follow as we were wont the manuscript of Peter Pattieson) than in the rapid conveyance of intelligence and communication betwixt one part of Scotland and another. It is not above twenty or thirty years, according to the evidence of many credible witnesses now alive, since a little miserable horse-cart, performing with difficulty a journey of thirty miles per diem, carried our mails from the capital of Scotland to its extremity. Nor was Scotland much more deficient in these accommodations, than our richer sister had been about eighty years before. Fielding, in his Tom Jones, and Farquhar, in a little farce called the Stage-Coach, have ridiculed the slowness of these vehicles of public accommodation. According to the latter authority, the highest bribe could only induce the coachman to promise to anticipate by half an hour the usual time of his arrival at the Bull and Mouth.

But in both countries these ancient, slow, and sure modes of conveyance, are now alike unknown; mail-coach races against mail-coach, and high-flyer against high-flyer, through the most remote districts of Britain. ${ }^{109}$
}

${ }^{109}$ Scott, Walter. The Heart of Midlothian. Op. Cit. p.1-2. 
A relação desse relato técnico sobre os meios de transporte com a intriga é dupla: ela justifica o acidente com a carruagem que transportava os dois advogados, responsáveis pela apresentação da história de Jeanie Deans ao narrador, o que concede à narrativa sua conexão histórica com a jurisprudência da época, afinal a história de Jeanie Deans é narrada por quem, de fato, é autoridade no assunto. E a explicação possibilita, igualmente, que o leitor "entenda" e "sinta" a extrema dificuldade enfrentada pela heroína do romance durante sua viagem até Londres; lembremos que, no romance, Jeanie Deans viaja a maior parte do tempo a pé, e mesmo quando consegue o transporte a adversidade é a mesma ${ }^{110}$. O narrador, posteriormente, reforça a dificuldade das viagens nesse tempo histórico:

In the present day, a journey from Edinburgh to London is a matter at once safe, brief, and simple, however inexperienced or unprotected the traveler.(...) But it was different in 1737. (...). 111

O romance de Balzac inicia-se esclarecendo o funcionamento das tipografias na província, as quais operavam de maneira arcaica se comparadas às de Paris:

\begin{abstract}
À l'époque où commence cette histoire, la presse de Stanhope et les rouleaux à distribuer l'encre ne fonctionnaient pas encore dans les petites imprimeries de province. Malgré la spécialité qui la met en rapport avec la typographie parisienne, Angoulême se servait toujours des presses en bois, auxquelles la langue est redevable du mot faire gémir la presse, maintenant sans application. L'imprimerie arriérée y employait encore les balles en cuir frottées d'encre, avec lesquelles l'un des pressiers tamponnait les caractères. Le plateau mobile où se place la forme pleine de lettres sur laquelle s'applique la feuille de papier était encore en pierre et justifiait son nom marbre. Les dévorantes presses mécaniques ont aujourd'hui si bien fait oublier ce mécanisme, auquel nous devons, malgré ses imperfections, les beaux livres des Elzevier, des Plantin, des Alde et des Didot, qu'il est nécessaire de mentionner les vieux outils auxquels Jérôme-Nicolas Séchard portait une superstitieuse affection; car ils jouent leur rôle dans cette grande petite histoire. Ce Séchard était un ancien compagnon pressier, que dans leur argot typographique les ouvriers chargés d'assembler les lettres appellent un Ours. (...) $)^{112}$
\end{abstract}

Aqui, a relação da descrição com a intriga é ainda mais acentuada. As desilusões de Lucien de Rubempré e David Séchard estão conectadas ao mundo especulativo em torno das tipografias. À medida que a modernização técnica

\footnotetext{
${ }^{110} \mathrm{Na}$ história real, Helen Walker vai até Londres a pé. Walter Scott modifica a jornada de Jeanie Deans para informar ao leitor as condições históricas dos meios de transporte da época.

${ }^{111}$ Scott, Walter. The Heart of Midlothian. Op. Cit. p.354.

112 Balzac, Honoré de. Illusions Perdues. Op. Cit. p.41-42. Itálico nosso.
} 
juntamente com as especulações capitalistas invade a pequena tipografia de Angoulême, as personagens têm o destino de suas vidas modificado.

"Essa pequena grande história", tanto para Balzac quanto para Walter Scott, diz respeito à história do homem comum, opondo-se à "vellha história", ou seja, à Clio clássica, a qual se dedica apenas aos grandes acontecimentos no plano público. Balzac depreendeu dos romances de Walter Scott o foco do olhar do narrador, isto é, se era possível avaliar historicamente a vida cotidiana do homem medieval, a qual, na definição de Ann Rigney, constitui o "pano de fundo dos acontecimentos políticos" ${ }^{\text {"113, }}$, não seria impossível transferir essa representação histórica para o presente. A preocupação com a representação da história social direciona o olhar do narrador para a representação da vida humana em sua totalidade, sendo necessário retratar as várias forças envolvidas na tensão sóciohistórica. Se considerarmos que o olhar do historiador está voltado para a alteridade $^{114}$, a estrutura literária dos romances de Walter Scott e Balzac obedece rigorosamente a esse princípio. Em geral, a narrativa de seus romances é construída a partir de uma dicotomia:

- contrastes topográficos: As terras altas e as terras baixas; Paris e a Província; Escócia e a Inglaterra; La rue Neuve-Sainte-Geneviève e Le Faubourg Saint-Germain.

- contrastes entre as personagens, sem que impere uma noção maniqueísta, mas perfis diferentes que constituem o momento sóciohistórico: Effie Deans e Jeanie Deans; Lucien de Rubempré e Daniel D’Arthez; Lucien de Rubempré e David Séchard;

- contraste temporal: passado e presente.

\footnotetext{
113 "Background to the political events". IN: Rigney, Ann. Op. Cit. p.28.

114 "A perspectiva do historiador é diferente: ele sabe que o homem é o tempo, sabe que ele muda, que é finito e não deseja contemplar ou conhecer o que está fora do tempo e não muda, que para ele é inabordável e incognoscível. Seu interesse é pelo "ou", pela alteridade humana, que é sobretudo temporal". IN: Reis, José Carlos. Op. Cit. p.182.
} 
Quanto à composição das personagens, ela é pautada, igualmente, pelo compromisso com o conhecimento histórico. A personagem responde individualmente a um amplo movimento do processo histórico:

Celle-ci tient, d'ailleurs, à la propension qu'ont les imitateurs de Scott à faire de l'historique à peu de frais, ils trouvent un détail, ils s'en emparent et le plaquent dans leurs livres: ils généralisent des particularités, au lieu de particulariser des généralités, principe essentiel de Walter Scott. ${ }^{115}$

"Eles generalizam as particularidades, em vez de particularizarem as generalidades, princípio essencial de Walter Scott”: esse apontamento de Balzac é um indício de sua compreensão de um procedimento narrativo relacionado à representação histórica. Ora, não é suficiente, segundo a ótica balzaquiana, representar o sujeito histórico, compondo-o com um dado histórico específico da realidade. Um exemplo desse procedimento insuficiente seriam as investidas românticas de retratar as grandes personagens históricas, "apropriando-se" da biografia dessas figuras públicas e fazendo disso o traço histórico de sua narrativa. Para Balzac, o fato de "revestir" a narrativa romanesca de personagens históricas reais não resulta no conhecimento histórico de uma época, não sendo, portanto, um procedimento de representação histórica. O autor da Comédia Humana pensa em concordância com Walter Scott:

\begin{abstract}
Le roman ne peut admettre qu'en passant une grande figure. Ainsi, Cromwell, Charles II, Marie Stuart, Louis XI, le Prétendant, Élisabeth, Richard Cœur-de-Lion, tous les grands personnages que le créateur du genre a mis en scène, ne parassait jamais qu'un moment ou au dénoument, le drame du conteur marche vers eux, comme dans leur temps marchaient les hommes et les choses. On a vécu dans le pourpoint des créations secondaires de Walter Scott, on a épousé les intérêts de tous les acteurs, quand on avance avec eux vers la grande figure historique. II n'a jamais fait d'un immense évenement le sujet de son livre ; mais il en a expliqué minutieusement les causes, en peignant l'esprit et le mœurs de toute une époque, et se tenant dans le milieu social, au lieu de se placer dans la haute région des grands faits politiques. Vous ne trembleriez pas de voir arriver Cromwell à Woodstock, s'il s'agissait de la prise de Charles ler; vous savez que Charles ler a été décapité; mais vous tremblez pour les personnages secondaires dont le sort est oublié par les historiens; vous tremblez pour le brave étudiant qui défie le Protecteur. Quand l' Écossais a voulu nous faire vivre avec Marie Stuart, et nous intéresser à son évasion, il ne l'a pas emprisonnée à Fontheringay, d'où elle n'est sortie que morte, mais à Lochleven. ${ }^{116}$
\end{abstract}

\footnotetext{
${ }^{115}$ Balzac. "Lettres sur la littérature, le théâtre et les arts". Op. Cit.p.183.

${ }^{116}$ Idem, Ibidem, p.170-171.
} 
O conhecimento histórico na narrativa romanesca é possível quando ela explica "as causas, retratando o espírito e os costumes de toda uma época", e quando "se mantém no meio social, em vez de se posicionar na alta esfera dos grandes fatos políticos". De nada vale o esforço de recriar uma personagem histórica, pois a tentativa sempre será idealizada, não sendo possível realmente conhecê-la na sua individualidade. O que é histórico são as articulações entre o fato e a vida humana. O autor é capaz, então, de recriar, de imaginar personagens que existiram "enquanto possibilidades, como perfis que retraçam sensibilidades. Foram reais "na verdade do simbólico" que expressam, não no acontecer da vida."117 $A$ relação das personagens com a realidade histórica é possível porque elas são capazes de representar as contradições, as misérias, as alegrias, a violência, a beleza, e outras especificidades do tempo histórico em que viveram. A Comédia Humana oferece ao leitor uma pletora de personagens que "particularizam as generalidades" históricas da Restauração, entre as quais a figura dos arrivistas em Eugène de Rastignac, dos banqueiros no Barão de Nucingen, a aristocracia parisiense na Condessa de Beauséant, os comerciantes em César Birotteau, as "lorettes" em Coralie, Esther, entre muitos outros exemplos. A importância dessas personagens, além de sua interessante caracterização e relevância na intriga, diz respeito a sua conexão com o movimento geral da sociedade.

A caracterização material das personagens segue 0 detalhismo do antiquarianismo na construção da sua materialidade, daí o cuidado com o vestuário, o linguajar, os trejeitos, o que comem, os lugares que frequentam, onde moram, etc. A construção material do enquadramento histórico, através do emprego de uma minuciosa descrição atenta à realidade, seria o terceiro procedimento imprescindível à representação histórica. A descrição nunca é acessória se está vinculada à intenção de representar historicamente a vida humana.

Quel que soit le nombre des accessoires et la multiplicité des figures, un romancier moderne doit, comme Walter Scott, l'Homère du genre, les grouper d'après leur importance, les subordonner au soleil de son système, un intérêt ou un héros, et les conduire comme une constellation brillante dans une certain ordre. ${ }^{118}$

\footnotetext{
${ }^{117}$ Pesavento, Sandra Jatahy. Op. Cit. p. 4.

${ }^{118}$ Balzac. "Lettres sur la littérature, le théâtre et les arts". Op. Cit. p.149.
} 
e ainda :

L'art du romancier consiste à être vrai dans tous les détails, quand son personnage est ficitf. $^{119}$

Como afirma Leyla Perrone-Moisés, as descrições nos romances balzaquianos "não constituem uma parada na narrativa (para informar, distrair, ou convencer o leitor), mas são uma continuação da narrativa em outro nível" ${ }^{120}$. Para a crítica, as descrições possuem, ali, um "papel produtor", pois elas também relatam, "contam coisas". No caso do romance analisado pela crítica, Le Lys dans la Valée, as descrições representariam o que era vetado à narrativa por um código moral, ou seja, o desejo sexual pulsante entre as personagens do romance. Segundo nossa análise, se a ideia de representar a "história doméstica" é o projeto literário balzaquiano, o contraste entre o código moral e as descrições, introduzidas na narrativa para indicar metaforicamente o desejo sexual, criando um jogo entre 0 dito/e o não dito, acaba nos revelando os aspectos históricos das relações amorosas naquela época. O leitor é capaz de apreender a rigidez do código moral e as manobras efetuadas, no mundo doméstico, para contorná-la. Há sem dúvida uma representação histórica das relações entre homem e mulher, enfim, da vivência do desejo na Restauração. Dessa maneira, se as personagens são fictícias, os detalhes das descrições são reais e denunciam a verdade das intenções delas e, por extensão, retratam a verdade do tempo histórico. Podemos aferir que Balzac compreendeu a importância ou "produtividade" da descrição na narrativa, quando postula um dos princípios do "trovador moderno": "L'art du romancier consiste à être vrai dans tous les détails,(...)"[ "A arte do romancista consiste em ele ser verdadeiro em todos os detalhes"]. ${ }^{121}$

Contudo, se esses procedimentos que acabamos de comentar são indispensáveis para a representação histórica na narrativa romanesca, quando

\footnotetext{
${ }^{119}$ Balzac. "Lettres sur la littérature, le théâtre et les arts". Op. Cit. p.177.

${ }^{120}$ Perrone-Moisés, Leyla. Flores da escrivaninha. São Paulo, Companhia das Letras, 1990, p.45.

${ }^{121}$ Balzac. "Lettres sur la littérature, le théâtre et les arts". Op. Cit. p.177.
} 
Balzac decide ser o historiador do presente, outros procedimentos que encontrara na narrativa scottiana divergem de seu projeto literário:

\begin{abstract}
Walter Scott élevait donc à la valeur philosophique de l'histoire le roman, cette littérature qui, de siècle en siècle, incruste d'immortals diamants la couronne poétique des pays où se cultivent les lettres. Il y mettait l'esprit des anciens temps, il y réunissait à la fois le drame, le dialogue, le portrait, le paysage, la description; il y faisait entrer le merveilleux et le vrai, ces élements de l'épopée, il faisait coudoyer la poésie par la familiarité des plus humbles langages. Mais, ayant moins imaginé un système que trouvé sa manière dans le feu du travail ou par la logique de ce travail, il n'avait pas songé à relier ses compositions l'une à l'autre de manière à coordonner une histoire complète, dont chaque chapitre eût été un roman, et chaque roman une époque. En apercevant ce défaut de liaison, qui d'ailleurs ne rend pas l'Écossais moins grand, je vis à la fois le système favorable à l'éxecution de mon ouvrage et la possibilité de l'exécuter. Quoique, pour ainsi dire, ébloui par la fécondité surprenante de Walter Scott, toujours semblable à lui-même et toujours original, je ne fus pas désespéré, car je trouvai la raison de ce talent dans l'infinie variété de la nature humaine. ${ }^{122}$
\end{abstract}

Balzac evidencia, como podemos notar no trecho acima, uma diferença importante entre a estrutura narrativa da Comédia Humana e a dos romances dos Waverley Novels. Embora, ele inicie a sua análise apontando a grandeza do projeto literário de Walter Scott, o qual incorpora à narrativa romanesca o saber e o conhecimento histórico, construindo um sentido para o passado histórico escocês e esse é o sentido filosófico que Balzac atribui aos romances de Scott - o que sobressai nessa análise é a diferença do aproveitamento que cada um faz do tempo histórico na narrativa. O "trovador moderno", como Balzac denominava Scott, traz para a Literatura um olhar que era restrito à História. Entretanto, um problema assoma da perspectiva do projeto balzaquiano: a falta de conexão entre as partes e o todo. Balzac quer, ao contrário de Walter Scott, que seus romances estejam conectados, formando uma História completa. A ideia de um projeto literário que falasse de uma totalidade corresponde à representação do presente histórico. A única maneira de alcançar a visibilidade desse tempo mutável seria conectando seus fragmentos, uma vez que o presente nunca está completo e está sempre se modificando. Como enfrentar, então, este paradoxo: como unificar uma história fragmentada? No prefácio do romance Une Fille d'Ève (1839), temos acesso ao conjunto de ideias que constituem o mecanismo favorável à representação histórica do presente. Ao se autoproclamar o historiador do presente, Balzac inicia um debate muito interessante sobre a construção do tempo na narrativa. Que questões, então, Balzac mobiliza nesse debate epistemológico em relação ao tempo?

${ }^{122}$ Balzac. "Avant-Propos" de la Comédie Humaine.Op. Cit. p. 285 
A primeira questão, mesmo que pareça óbvia, é a diferenciação entre o passado e o presente. No entanto, no plano da narrativa, há uma diferença entre um tempo histórico e outro. O romance histórico scottiano é um romance sobre o passado, e tal posicionamento implica um tipo de organização formal específica. Nos seus romances o narrador não é testemunha, não vivencia o que narra, ao contrário, ele possui uma "neutralidade" para falar do passado, sua voz é de quem está no presente afastado dos acontecimentos, enquanto que suas personagens "mediadoras" estão mergulhadas nos acontecimentos históricos. Guardada a distância, ele é capaz de narrar diferentes acontecimentos sem que eles tenham relação direta entre si, contudo, vale lembrar, que esses acontecimentos possuem um forte significado para o entendimento do presente, e quem faz a mediação entre a situação pretérita e a situação presente é o narrador. É comum encontrar comentários do narrador tais como "de acordo com as ideias da época", "os repetidos toques da trompa que era então sempre usada"123, "era o costume", "no dia 7 de setembro de $1736^{\prime \prime 24}$, etc.

Balzac, por sua vez, não deseja vasculhar o passado histórico da França, quer, ao contrário, compreender o vivido imediato. Para ele, Walter Scott havia estabelecido, definitivamente, a conexão de sentido com o passado histórico:

\begin{abstract}
Le seul roman possible dans le passé, Walter Scott l'a épuisé. C'est la lutte du serf ou de la bourgeoisie contre la noblesse, de la noblesse contre le clergé; de la noblesse et du clergé contre la royauté. Pour arriver à ses grands effets, II lui a fallu les rois, les reines et les grands, leurs points de cohérence avec les faibles. Autrefois tout était simplifié par les instituitions monarchiques; les caractères étaient tranchés: un bourgeois, marchand ou artisan, un noble entièrement libre, un paysan esclave, voilà l'ancienne société de L'Europe. $^{125}$
\end{abstract}

Para o autor francês, a representação histórica do passado é linear, pois ele é finito. O narrador deve apenas seguir a ordem cronológica clássica: passado,

\footnotetext{
123 "According to the ideas of the time (...)", " The repeated bursts of the French horn, which was then always used (...)" IN: Scott, Walter Sir. The Bride of Lammermoor. Oxford [England]; New York: Oxford University Press, 1991, p.59 e p.129.

124 "it was the costume (...)", "On the $7^{\text {th }}$ day of September 1736 (...)", IN: Scott, Walter Sir. The Heart of Midlothian. Op. Cit. p.22.

${ }^{125}$ Balzac. Une Fille d'Ève. Préface de la Première Édition. IN: Préfaces des Romans Français du XIX Siècle. Anthologie établie, présentée et annotée par Jacques Noiray. Paris: Le Livre De Poche,p.185.
} 
presente e futuro. Dessa maneira, a voz narrativa do presente olha para o passado para representá-lo. Ademais, a sociedade medieval era para o autor francês um momento político mais simples. Era um mundo mais "ordenado". Contudo, as mudanças do mundo capitalista burguês desestabilizaram completamente o mundo "linear" de outrora:

Aujourd'hui, l'Égalité produit en France des nuances infinies. Jadis, la caste donnait à chacun un physionomie qui dominait l'individu; aujourd'hui, l'individu ne tient sa physionomie que de lui-même.Les sociétés n'ont plus rien de pittoresque: il n'y a plus ni costume, ni bannières: il n'y a plus rien à conquérir, le champ social est à tous. II n'y a plus d'originalité que dans les professions, de comique que dans les habitudes. La forme faisant défaut, il a fallu que la littérature se jêtat dans la peinture de l'idée, et cherchait les émotions le plus délicates du cœur humain. 126

A organização social linear e claramente delineada de outrora é desarticulada pela sociedade do "parvenu". A possibilidade de ascensão social aberta a todos, independentemente de sua origem, imprime à sociedade francesa do período da Restauração um sentido de uniformidade, pois havia uma espécie de comportamento padrão, imposto pelas regras sociais burguesas. Era difícil compreender as especificidades dessa organização social que era guiada pelo "ouro" e pelo "prazer". Como afirma Paule Petitier:

Dans la société d'Ancien Régime, les mœurs correspondaient à la hiérarchie sociale, à la division fonctionnelle des conditions. Signes et distinctions renvoyaient clairements à un ordre social inscrit dans la loi. L'égalité juridique institué par la Révolution française a obscursi cette lisibilité immédiate du champ social. ${ }^{27}$ (...) L'uniformization des apparences résulte de l'extension à toutes les catégories sociales des «mœurs bourgeoises créées par la Révolution française.» (...) Balzac revient à plusieurs reprises sur les difficultés que présente l'uniformité des mœurs modernes au peintre de la société. À la différence du romancier historique à qu'il revient de peindre «les figures si vigoureusement modelées de l'ancient temps», l'«historien d'aujourd'hui» doit s'attacher à des "sociétés qui n'ont plus rien de pittoresque». Aussi le romancier définit-il sa tâche comme un travail sur «nuances» et les «détails». 128

${ }^{126}$ Balzac. Une Fille d’Ève. Préface de la Première. Op.Cit. p.186.

${ }^{127}$ Como já mencionamos acima, Balzac faz a mesma constatação.

128 Petitier, Paule. "Balzac, "historien des mœurs". IN: Mozet, Nicole et Petitier, Paule (éds.). Op.Cit.p.97: "Na sociedade do Antigo Regime, os costumes correspondiam à hierarquia social, à divisão funcional das condições. Signos e distinções remetiam claramente a uma ordem social inscrita na lei. A igualdade jurídica instituída pela Revolução Francesa obscureceu essa legibilidade imediata do campo social. (...) A uniformização das aparências resulta na extensão a todas as categorias sociais dos "costumes burgueses criados pela Revolução Francesa". (...) Balzac retorna muitas vezes à questão sobre as dificuldades que apresenta a uniformidade dos modos modernos para o pintor da sociedade. Ao contrário do romancista histórico, o qual deve se voltar à representação "dos tipos tão vigorosamente modelados dos tempos antigos", "o historiador de hoje" 
Diante dessa uniformidade, era preciso, mais do que nunca, "vasculhar" a sociedade. O narrador-historiador balzaquiano quer desmascará-la. Para tanto, há uma valorização do detalhe, pois é no pormenor que se encontram as diferenças em relação ao padrão. Na narrativa balzaquiana o detalhe é revelador - e, de modo geral, revelador do que é negativo - enquanto que em Walter Scott é constatação. Entretanto, em ambos os casos há uma relação direta entre esse dispositivo narrativo, isto é, a descrição, e o conhecimento histórico.

A representação do presente histórico na narrativa balzaquiana será, portanto, marcada por uma dimensão temporal mais complexa, unindo passado e presente, enquanto Walter Scott estrutura seu romance em torno de uma ordem cronológica linear e clássica. Balzac, na tentativa de apreender o caos da história do presente, compõe sua narrativa como um mosaico, unindo os fragmentos desse tempo histórico.

\begin{abstract}
Enfin, vous aurez le milieu d'une vie avant son commencement, le commencement après sa fin, l'histoire de la mort avant celle de la naissance.

D'abord, il en est ainsi dans le monde social. Vous rencontrez au milieu d'un salon un homme que vous avez perdu de vue depuis dix ans: il est premier ministre ou capitaliste, vous l'avez connu sans redingote, sans esprit public ou privé, vous l'admirez dans sa gloire, vous vous étonnez de sa fortune ou des ses talents; puis vous allez dans un coin du salon, et là, quelque délicieux conteur de la société vous fait en une demi-heure l'histoire pittoresque des dix ou vingt ans que vous ignoriez. Souvent cette histoire scandaleuse ou honorable, belle ou laide, vous sera-t-elle dite, le lendemain ou un mois après, quelquefois par parties. II n'y a rien qui soit d'un seul bloc dans ce monde, tout y est mosaïque. Vous ne pouvez raconter chronologiquement que l'histoire du temps passé, système inapplicable à un présent qui marche. ${ }^{129}$
\end{abstract}

Antes de analisarmos como Balzac estrutura a representação do mosaico na sua narrativa, seria importante investigar melhor o sentido do presente histórico. Paul Ricœur ${ }^{130}$ aborda alguns aspectos relacionados ao presente histórico que podem nos ajudar a compreender o seu significado. Para o filósofo, o presente histórico é configurado a partir de um momento axial, fundador de uma nova era. É o início, no tempo, de uma nova cadeia de acontecimentos. Além desse caráter

deve se ater às "sociedades que não têm mais nada de pitoresco". O romancista define, também, sua tarefa como um trabalho sobre "nuances" e detalhes".

${ }^{129}$ Balzac. Une Fille d’Ève. Préface de la Première Édition. Op. Cit. p.188. Itálico nosso.

${ }^{130}$ Ricœur, Paul. "Vers une Herméneutique de la Conscience Historique." IN : Le Présent Historique. Temps et Récit. Paris: Éditions du Seuil, 1985, tome III, p. 300-345. 
inaugural, o presente histórico é entendido como um "espaço comum de experiência". Por fim, o presente histórico é um tempo de crise, e sua construção narrativa deve lidar com a "força do presente". Segundo José Carlos Reis ${ }^{131}$, Ricœur se dedica ao esclarecimento da operação narrativa da história e sua tese maior diz respeito à inteligibilidade do tempo, a qual somente é possível quando articulada na narrativa.

Conceitualmente, o tempo histórico é uma solução poética que permite a narrativa da vida humana, pois é a "organização que a própria vida coletiva se dá (nesse sentido é um vivido concreto, efetivo, é uma auto-organização da vida social) e é conhecimento desse vivido". ${ }^{132}$ A discussão sobre tempo histórico, no nível narrativo, apresenta algumas correlações com a narrativa romanesca balzaquiana.

A ascensão social vinculada à acumulação de capital será o momento axial que engendra os novos acontecimentos na sociedade da Restauração. A crise para Balzac é a multiplicidade de vidas humanas arrastadas para dentro da "força" do presente. O momento axial, referido por Ricœur, corresponde à escolha efetuada por Balzac de representar a sociedade da Restauração, que passará a ser, então, o eixo da Comedia Humana. A partir desse momento revolucionário, portanto de crise, as intrigas serão desenvolvidas, conectadas umas às outras, no todo da Comédia Humana. A representação histórica da vida humana na sociedade da Restauração, sob a égide da ascensão do capitalismo, e a nova ordem sócio-política - ou seja, "experiência comum"- é realizada a partir da narrativa de fragmentos de histórias individuais, as quais, interligadas, compõem a história coletiva. A dialética da representação histórica entre o individual e o coletivo é reorganizada na cadeia de intrigas que forma o mosaico balzaquiano.

É a partir desse eixo central que podemos compreender a dimensão histórica da narrativa. Mesmo que o objeto da representação histórica seja a sociedade da Restauração, isto é, o presente, isto não significa que as relações com o passado sejam descartadas, afinal só é possível, realmente, "compreender" e "sentir" o

\footnotetext{
${ }^{131}$ Reis, José Carlos. Op. Cit. p.136.

132 Idem, Ibidem, p.184.
} 
presente contrastando-o com o passado. Porém, no plano narrativo o ordenamento linear, passado seguido do presente, é substituído pela presença do passado no presente, como se os dois tempos coexistissem. Se a História é conhecimento do passado, a narrativa balzaquiana não abandona esse princípio. É a ordem da lógica de representação desses tempos históricos que é modificada. Nos romances da Comédia Humana o passado assombra a vida de inúmeras personagens. Passamos, então, a observar suas aventuras na nova ordem social, compreendendo, a partir desse contraste, o processo histórico. Por exemplo, fica mais claro para o leitor compreender a ascensão de algumas personagens e a decadência de outras, considerando que esses altos e baixos estão vinculados ao processo histórico. A estrutura narrativa do romance L'Envers de l'Histoire Contemporaine $^{133}$ ilustra bem esse procedimento. É evidente que cada romance articula essas questões de maneira diferente, mas há sempre a relação com o eixo central de que falamos acima. Porém, a estrutura desse romance nos parece muito clara, no que diz respeito ao contraste passado/presente.

O romance é dividido em duas partes: a primeira é intitulada "Madame de la Chanterie" e a segunda, "O Iniciado." Na primeira parte, o jovem Godefroid entra em contato com a sociedade secreta liderada por Madame de la Chanterie e, sem saber o que se passa, o jovem forma suas próprias impressões sobre o grupo. Aos poucos, Godefroid torna-se mais próximo e acaba sendo informado da história pessoal de cada um. Em sua maioria, essas personagens foram figuras políticas importantes ou membros da aristocracia. Todas têm uma relação com o passado histórico da França, ou seja, o período anterior a 1814. À medida que as histórias vão sendo reveladas a Godefroid, distinguimos a diferença de como viviam e vivem. Além das contingências inerentes à vida, há uma razão histórica referente a essa mudança. Os acontecimentos históricos os forçaram a outra experiência de vida.

\footnotetext{
${ }^{133}$ L'Envers de L'Histoire Contemporaine é o último romance da Comédia Humana, publicado em 1848. O romance trata de uma sociedade secreta que se dedica à caridade. A personagem central do livro é Godefroid, jovem provinciano que vai a Paris para estudar Direito. Ele é a típica personagem balzaquiana que acaba se afastando de suas "boas intenções" iniciais e se perde na capital das tentações. Paris, símbolo da ascensão social, é corruptora. Essa é a trajetória de outras personagens conhecidas da Comédia Humana, tais como: Lucien de Rubempré, Rastignac, Raphael de Valentin, etc. Cansado, falido, à procura de um lugar para morar e um novo estilo de vida, Godefroid encontra a sociedade de Mme de Chanterie que o acolhe, contanto que o jovem abrace, verdadeiramente, o ideal do grupo. Godefroid recebe, então, uma missão: ajudar M. Bernard e sua filha doente.
} 
As histórias são narradas a Godefroid por M. Alan, em um longo diálogo, à maneira scottiana. Os membros do grupo adotam nomes diferentes e passam a se identificar apenas pelo primeiro nome. O motivo é que esses nomes estão diretamente ligados aos acontecimentos históricos do passado:

- (...) je vous dirai que dans le monde monsieur Nicolas portait le nom de marquis de Montauran, et monsieur Joseph celui de Lecamus, Baron de Tresnes; mais, pour nous comme pour tout le monde, ces noms-là n'existent plus (...).

En attendant prononcer ces deux noms, l'un si célèbre dans les fastes du royalisme par la catastrophe qui termina la prise d'armes des Chouans au début du Consulat, l'autre si vénéré dans les fastes du vieux du Parlement de Paris, Godefroid ne put retenir un tressaillement; mais en regardant le débris des deux plus grandes choses de la monarchie écroulée, la Noblesse et la Robe, il n'aperçut aucune inflexion dans les traits, aucun changement de physionomie qui révélât en eux une pensée mondaine. Ces deux hommes ne se souvenaient plus ou ne voulaient plus se souvenir de ce qu'ils avaient été. Ce fut une première leçon pour Godefroid.

- Chacun de vos noms, messieurs, est toute une histoire, leur dit-il respectueseument.

- L'histoire de notre temps, répondit monsieur Joseph, des ruines $!^{134}$

Durante a Restauração, as personagens tornam-se pessoas comuns, anônimas, o prestígio que seus nomes guardavam no passado histórico já não faz mais sentido em uma sociedade que prioriza a ascensão social e econômica. Ao renunciarem a sua fortuna, as personagens renunciam a sua posição social. No presente histórico, os nomes simbolizam apenas o término de uma ordem social, ou seja, não passam de "ruínas".

Antes de iniciar a "história" sobre o passado, a personagem tece algumas considerações, que recebem o seguinte comentário do narrador: "Após essa espécie de prefácio, não saberíamos exprimir a que grau de curiosidade o neófito chegou (Après cette espèce de préface, on ne saurait exprimer à quel degré de curiosité le neophyté arriva)". ${ }^{135}$ Aqui, o neófito é Godefroid, que se iniciará nos segredos do grupo, mas é também aquele, como o leitor, que entrará em contato com o passado histórico . O comentário do narrador nos remete aos prefácios de Walter Scott, em que o leitor é também o neófito que se inicia na história escocesa. Após seu "prefácio", M. Alan inicia sua narrativa:

\footnotetext{
${ }^{134}$ Balzac. L'Envers de L'Histoire Contemporaine. Paris: Gallimard, 1970, p.57-58.

${ }^{135}$ Idem, Ibidem, p. 85.
} 
-J'avais alors un peu plus de trente ans, dit-il, nous étions en 98, autant qu'il m'en souvient (...) Un matin, un peu avant l'heure de mon déjeuner, à neuf heures, ma vieille femme de ménage m'annonce un des quelques amis que j'avais conservés au milieu des orages de la Révolution. Aussi mon premier mot fut-il une invitation à déjeuner. Mon ami, nommé Mongenod, garçon de vingt-huit ans, accepte, mais d'un air gêné; je ne l'avais pas vu depuis 1793. (...)

- Quand Mongenod s'assied, reprit le bonhomme Alan, je m'aperçois que ses souliers sont horriblement usés. Ses bas mouchetés avaient été si souvent blanchis que j'eus de la peine à reconnaître qu'ils étaient en soie (...). Enfin l'aspect de la houppelande (on nommait ainsi une redingote ornée d'un seul collet en façon de manteau à la Crispin) acheva de me convaincre que mon ami était tombé dans le malheur.

- (...) A la mort de son père, em 1787, Mongenod s'était trouvé plus riche que moi. (...) Mongenod fut alors ce qu'on appellait un charmant cavalier, II avait des galenteries.(...)

Vous pouvez maintenant imaginer combien fut grande ma surprise en apercevant chez Mongenod les symptômes de la misère qui dégradaient pour moi le jeune, l'élégant Mongenod de 1787, quand mes yeux quittèrent son visage por examiner ses vêtements.(...)

- (...) En parlant de notre vie avant la Révolution, nous restâmes attablés jusqu'à trois heures après midi, comme les meilleures amis du monde. Mongenod me raconta comment il avait perdu sa fortune. D'abord, la réduction des rentes sur L'Hôtel de Ville lui avait enlevé les deux tiers de ses revenues, car son père avait placé sur La Ville la plus forte partie de ses capitaux $(\ldots){ }^{136}$

A história da vida de M. Alan e de seu amigo Mongenod entrecruza-se com a História da França. Os dois amigos se conheceram antes da Revolução Francesa e a partir desse momento a narrativa evidencia como a vida de cada um vai se alterando de acordo com os acontecimentos históricos. O relato de M. Alan pontua os hábitos no vestir, os costumes da vida social, as dificuldades econômicas de cada um em razão do contexto sócio-histórico, sendo todas essas especificidades indicadas por datas precisas. No momento do encontro, que se passa após a Revolução Francesa - "nós estávamos em 98"- M. Alan se surpreende com a miséria de Mongenod visualizada em suas roupas. O jovem rico de 1787, portanto antes da Revolução, perde sua renda e suas regalias aristocráticas durante 0 período revolucionário.

Para ajudar seu antigo amigo, M. Alan Ihe empresta uma grande quantia; após um ano, Mongenod não paga sua dívida, obrigando M. Alan a entregar o caso a um oficial de justiça. Finalmente, Mongenod aparece e o procura. O ano é 1799, período napoleônico, época positiva para as finanças:

Le Dix-Huit Brumaire avait eu lieu, tout allait au mieux, les fonds montaient, et Bonaparte était parti pour aller livrer la bataille de Marengo. - II est malhereux, monsieur, dis-je en recevant Mongenod debout, que je ne doive votre visite qu'aux instances d'un huissier.

${ }^{136}$ Balzac. L'Envers de L'Histoire Contemporaine. Paris: Gallimard, 1970, p. 85-91. 
Mongenod prend une chaise et s'assied. - Je viens te dire, me répondit-il, que je suis hors d'état de te payer.

- Vous m'avez fait manquer le placement de mon argent avant l'arrivée du Premier Consul, moment où je me serais fait une petite fortune.... ${ }^{13}$

Se Mongenod tivesse pago sua dívida, tudo teria sido diferente para M. Alan. A narrativa continua dessa maneira, atrelando as contingências da vida das personagens ao processo histórico. Temos a nítida impressão de que suas vidas seguiram o rumo que seguiram não só pelas escolhas pessoais de cada um, mas também como consequência dos acontecimentos históricos.

Toda a primeira parte é tomada pelas "revelações" sobre o passado das personagens. Já na segunda, a intriga se desenvolve totalmente no presente, e aqui quem "controla" a narrativa é o narrador. Se antes as personagens revelam o passado por meio de longos diálogos, aqui as revelações são realizadas pelo narrador. É no presente, na sociedade da Restauração, que todas as personagens reiniciam suas vidas. O capítulo não se intitula "O Iniciado" à toa. Godefroid, assim como os leitores, será iniciado na dimensão histórica do presente. Após o encontro com as figuras do passado, Godefroid pode compreender melhor o tempo em que vive, e sua missão, como a de todos os outros membros do grupo, é a sobrevivência em Paris. O capítulo oferece ao leitor a paisagem parisiense típica dos romances de Balzac, cheias de personagens mesquinhas e arrivistas, pensões mal ajambradas, luxos extremados, famílias falidas e nobres decadentes.

$\mathrm{Na}$ narrativa balzaquiana, a vida presente das personagens sempre guarda uma relação com o passado, muitas vezes misteriosa, a situação social de uma personagem nunca é totalmente o que pensamos que seja. L'Envers de l'histoire Contemporaine condensa essa conexão que em outros romances é mais dispersa. O segredo do grupo é na verdade um emblema das alterações históricas na vida pessoal humana. Há sempre um dado a ser revelado, pois a civilização de 1814 em diante é uma trama complexa formada por muitas histórias entre o passado e o presente, em que nada mais é estável. A sociedade da Restauração é um mosaico.

\footnotetext{
${ }^{137}$ Balzac. L'Envers de L'Histoire Contemporaine. Op. Cit. p.101.
} 
A construção narrativa como mosaico somente é possível a partir da relação entre $\mathrm{o}$ narrador-historiador e o leitor. $\mathrm{O}$ narrador-historiador - e aqui devemos pensá-lo em sua ampla extensão na Comédia Humana - é como se fosse um artesão conectando suas peças na tentativa de formar um desenho desta sociedade. Ele é o "delicioso narrador da sociedade" que desvenda ao leitor a história oculta anterior e posterior ao "redingote". O leitor, ao se movimentar do meio do salão - e, portanto, da leitura de um romance a outro - até um canto qualquer, descobre as nuances da história do presente: o que pensa ser o começo pode ser o fim, o fim, talvez o meio; tudo dependerá da perspectiva narrativa. Um procedimento que viabiliza a representação histórica do sentido fugidio e confuso do momento de crise, ou seja, do presente histórico, é o retorno das personagens. O uso desse procedimento não é invenção de Balzac, porém o elo que estabelece entre as personagens e a intriga, criando um sentido ontológico do presente, é uma característica particular de sua obra.

Novamente, é Walter Scott quem the indica os meios de representação, mesmo que seja pela negativa. Ao entrever um defeito de "liaison" na obra do "trovador moderno", Balzac percebe que a tensão do presente histórico é uma unicidade $^{138}$. Pelo bem ou pelo mal, a crise está colocada para todos os indivíduos, os quais estão unidos na urdidura do presente histórico. $O$ apontamento balzaquiano de que o autor escocês "não tinha sonhado em unir suas composições uma à outra, de modo a coordenar uma história completa, na qual cada capítulo é um romance e cada romance uma época"139, traduz seu projeto literário e a maneira como irá concretizá-lo. Para representar a história do presente, ou seja a "experiência comum", era preciso um narrador que "coordenasse" essa história.

\footnotetext{
138 A noção de unicidade contrapõe-se à representação histórica do passado, pois a distância no tempo amplia os fatos que estariam possivelmente correlacionados às mudanças históricas. Ao analisar as mudanças ocorridas no plano sócio-cultural, pode-se averiguar a diversidade dos fatores envolvidos, enquanto que a observação do presente tende a evidenciar apenas um fator. No caso de Balzac, o foco é o desenvolvimento do capitalismo.
}

${ }^{139}$ Balzac. "Avant-Propos" de la Comédie Humaine.Op. Cit. p286. 
3- O narrador balzaquiano: testemunha das circunstâncias históricas.

O narrador-historiador balzaquiano, em vez de indicar o rastro do tempo que se foi, como o faz o narrador-historiador scottiano, prioriza o caráter único da "experiência comum". Seu objetivo é deslindar o complexo de histórias que constituem o presente, as quais são unidas pelas duas forças atuantes desse tempo histórico: o ouro e o prazer. O ponto de vista do narrador balzaquiano tem como base histórica o desenvolvimento do capitalismo e o agravamento das contradições provocadas por esse sistema ${ }^{140}$. O narrador diante dessa realidade, que estaria se concretizando, posiciona-se estrategicamente no âmago do conflito. É a partir daí que constrói as "cenas" que compõem o mosaico da sociedade da Restauração. Esse é o lugar de mediação entre história e ficção. Cabe ao narrador, sujeito histórico, apresentá-lo ao leitor, e o faz tanto pelo viés da admiração como do horror:

II s'applaudit de la grandeur, de la variété, de la beauté, de la fécondité de son sujet,quelque déplorable que le fassent, socialement parlant, la confusion des faits les plus opposés, l'abondance des matériaux, l'impétuosité des mouvements. Ce désordre est une source de beautés. ${ }^{141}$

No capítulo que discute o entrecruzamento de história e ficção, Paul Ricœur assinala que a memória do horror, para o conhecimento histórico, confere ao fato um caráter único. O horror, em contraponto à admiração, isola o fato histórico "tornando-o incomparável, incomparavelmente único, unicamente único."142 projeto literário balzaquiano de "apreender o século", na definição de José-Luiz

\footnotetext{
${ }^{140}$ O referencial do ponto de vista do narrador é o do movimento dialético das contradições do devir da "capitalização do espírito burguês", como analisa Lukács: "Tandis que les écrivains réalistes ultérieurs décrivent la capitalisation déjà accomplie de l'esprit bourgeois, Balzac met en scène l'accumulation primitive dans toute la sombre splendeur de son atrocité. IN: Lukács, Georg. Balzac et le Réalisme Français. Illusions Perdues. Traduit de l'allemand par Paul Laveau. La Découverte/Poche. Paris: 1999, p.62: "Enquanto os escritores realistas posteriores descrevem a capitalização já consumada do espírito burguês, Balzac coloca em cena a acumulação primitiva em todo esplendor sombrio de sua atrocidade."

${ }^{141}$ Balzac. Une Fille d'Ève. Préface de la Première Édition. Op. Cit. p.187.

142 «(... ) en rendant incomparable, incomparablement unique, uniquement unique.» Ricœur, Paul. "L'Entrecroisement de l'Histoire et de la Fiction." Temps et Récit. Paris: Éditions du Seuil, 1985, p.273.
} 
$\operatorname{Diaz}^{143}$, não se concretiza sem a veneração dicotômica (horror/admiração) desse século em crise. Paixão é veneração. Talvez seja essa paixão que Balzac insistiu em dizer que faltava a Walter Scott. A afirmação de que "Walter Scott não tem paixão" é repetida em seus textos críticos algumas vezes. Paixão, aqui, é entendida como uma construção narrativa que venera os horrores do tempo histórico. Não que Walter Scott não se atenha com a mesma intensidade ao fato histórico, mas o seu olhar é menos descontente em relação a ele. Scott observa o tempo vivido com mais tranqüilidade e sua observação é mais objetiva, pautada pelo viés de um projeto de construção de uma identidade nacional, daí a falta de "paixão".

Para "apreender" o sentido histórico dessa "desordem que é uma fonte de beleza”, o narrador deve organizá-la, catalogá-la, investigá-la, enfim, ele deve "coordenar" sua apresentação. Nesse sentido, o narrador-historiador balzaquiano revela e explica ao leitor o presente histórico. Primeiramente é preciso trazer à tona o que, sob as máscaras do comportamento social burguês, está escondido. narrador balzaquiano interessa-se pela "história doméstica", não somente em sua acepção social, como havia sido iniciada nos romances de Scott, mas também no sentido literal do vocábulo "doméstico". No mundo burguês, é no espaço interno dos lares nobres do Faubourg St. Germain ou das pensões como as de Mme Vauquer, multiplicadas na Comédia Humana, que o narrador encontra as "nuances" e os "detalhes", isto é, as pequenas peças que compõem seu mosaico.

Em Illusions Perdues, há um trecho em que o narrador descreve o que se passa nas coxias de um teatro que ilustra muito bem, no nível simbólico, a necessidade da revelação dos bastidores da história do presente. Sem o olhar que "vasculha" as coxias, o leitor não é capaz de, verdadeiramente, visualizar a história da Restauração.

Sur un signe de Lousteau, le portier de l'Orchestre prit une petit clef et ouvrit une porte perdue dans un gros mur. Lucien suivit son ami, et passa soudain du corridor illuminé au trou noir qui, dans presque tous les théâtres, sert de communication entre la salle et les coulisses. Puis, en montant quelques marches humides, le poète de province aborda la coulisse, où l'attendait le spectacle le plus étrange. L'étroitesse des portants, la hauteur du théâtre, les échelles à quinquets, les décorations si horribles vue de près, les acteurs plâtrés, leurs costumes si bizarres et faits d'étoffes si grossières, les garçons à veste huileuses, les cordes qui pendent, le régisseur qui se promène son chapeau sur la tête, les comparses assises, les

${ }^{143}$ Diaz, José-Luiz. "Saisir le Siècle". IN: Mozet, Nicole et Petitier, Paule (éds.). Op.Cit.p261-280. 
toiles de fond suspendues, les pompiers, cet ensemble de choses bouffonnes, tristes, sales, affreuses, éclatantes, ressemblait si peu à ce que Lucien avait vu de sa place au théâtre que son étonnement fut sans bornes. ${ }^{144}$

Se compararmos a sociedade burguesa do presente histórico, representada nos romances de Balzac, com esse espaço teatral, verificamos que ela é um "espetáculo estranho". Assim como no teatro, a vida pública é uma representação, uma ilusão, e somente quando olhamos para a vida privada somos capazes de desfazer o engodo, de conhecer a faceta real do processo civilizatório e "apreender" o tempo histórico. O narrador da Comédia Humana deseja nos apresentar o mundo das coxias. É dali que nos mostra as contradições do processo histórico. Quando vistos de perto, os objetos, os atores são bem desiguais se comparados à cena. Sem o olhar do narrador-historiador, o qual guia o leitor de um "corredor iluminado" até esse "buraco escuro", este último não seria capaz de visualizar "esse conjunto de coisas bufonas, tristes, sujas, horrendas, brilhantes". A imagem é paradoxal, porém é a ideia de representação histórica em Balzac: a clareza está no escuro, a História está nos bastidores, nas contradições.

A razão desse "espetáculo estranho" está relacionada à vivência, no plano individual, das mudanças sócio-econômicas. O narrador já havia advertido no capítulo introdutório de La Fille aux yeux d'or: "Ouro e prazer. Considere essas duas palavras como uma luz". Na França de 1814 em diante, a sociedade testemunha o início de uma era em que tudo tem um valor de troca, todos se transformam em mercadoria, é o momento em que a "reificação resplandece no frescor da aurora" Esse é o evento histórico da Comédia Humana. O momento axial do presente histórico se estende ao futuro, não há um futuro possível além da nova ordem social:

- Entendez-vous? dit Népomucème à Godefroid. Il est toqué pour sûr, le vieux bonhomme !...

- Sais- tu comment tu seras à son âge ...

-Oh ! que oui! je le sais ! répondit Népomucème. Je serais dans un sucrier.

- Dans un sucrier?

\footnotetext{
${ }^{144}$ Balzac. Illusions Perdues. Paris: Le Livre de Poche, 2006, p.358.

145 "La réification resplendit dans la fraîcheur de l'aube (...)" IN: Adorno, Theodor W. "Lecture de Balzac". Notes sur la Littérature. Traduit de l'allemand par Sibylle Muller. Paris: Flammarion, 1984, p.84.
} 
- Oui, l'on aura sans doute fait du noir avec mes os. J'ai vu les charretiers des raffineurs assez souvent à Montsouris venir chercher du noir pour leurs fabriques; et ils m'ont dit qu'ils en employaient à faire le sucre. ${ }^{146}$

Nesse trecho, a falta de hesitação de Népomucème em responder a Godefroid sobre seu futuro é um traço marcante da visão balzaquiana acerca do presente histórico. Não há como escapar ao movimento de uma sociedade que transforma tudo e todos em "mercadoria". Assim, para o simplório Népomucème seu futuro está em um açucareiro. A ironia do trecho se constrói com o contraste entre a ingenuidade e a assertividade do pobre rapaz. À pergunta feita por Godefroid - "Em um açucareiro?"- em um tom um tanto surpreso e zombeteiro, Népomucème responde com uma assertividade mordaz, pois, de fato, o carvão de osso era usado, não para "fazer" açúcar, mas no seu refino. Dessa forma, o futuro do rapaz está circunscrito no processo de reificação.

Para organizar esse mundo acelerado, testemunha de constantes revoluções, era preciso um narrador que "coordenasse" o caos. A representação desse tempo caótico não segue mais a ordem cronológica clássica; no presente, sob a aparente uniformidade do comportamento burguês, não sabemos onde começa ou termina a história, sendo assim, o narrador balzaquiano entrelaça as "pequenas" histórias que compõem o presente em uma "grande pequena história", ou, sua Comédia Humana. Preservando o princípio de coerência entre a representação histórica e a narrativa romanesca, Balzac compõe sua narrativa sobre a história do presente seguindo os princípios que sua personagem D’Arthez aconselha a Lucien - "tantôt en travers, tantôt par la queue; enfin variez vos plans, pour n'être jamais le même" -, isto é, o olhar do narrador balzaquiano oferece ao leitor uma história completa do presente, descrevendo-a em diversos ângulos, como um mosaico, narrando as pequenas histórias já iniciadas, ou pelo fim, variando os planos, conseguindo assim vencer a dificuldade em representar o tempo do "devir".

O narrador é, portanto, a solução encontrada por Balzac para enfrentar a dificuldade de retratar o presente enquanto tempo histórico no plano narrativo, pois o autor lhe atribui uma penetração analítica de quem sabe tudo e pode explicar

${ }^{146}$ Balzac. L'Envers de L'Histoire Contemporaine. Op.Cit. p.230. 
tudo, uma vez que o narrador está inserido no tempo histórico que narra. Ele não precisa mais da pesquisa nos manuscritos, das testemunhas que vivenciaram os fatos passados, necessários a quem fala sobre um tempo passado. O narrador balzaquiano é a testemunha de seu tempo. Ele fala "do meio do salão" sobre o que vê, o que sente, e compartilha seu conhecimento com o leitor. Seu ponto de vista é concomitante aos acontecimentos históricos e, por esse motivo, reproduz a realidade histórica como a enxerga, ou seja, fragmentada, como definida em seu prefácio: "o começo depois do fim, a história da morte antes da do nascimento".

Outro fator aliado ao olhar de dentro da história, ou seja, o ponto de vista de quem é testemunha, de quem se encontra "no meio do salão", é uma possibilidade de atribuir à sociedade da Restauração suas cores, seus tons, enfim, seu verdadeiro ritmo histórico. Inserido na "história doméstica", o narrador consegue verificar as lacunas desse mundo e, assim, desfazer suas ilusões. O narrador é capaz, desse ponto de vista, de expor as articulações que estão por trás dos acontecimentos sociais. Sob a aparente "igualdade" social da Restauração, ele nos revela as suas muitas desigualdades, denunciando os "hábeis maquinistas" responsáveis por tais articulações.

Vejamos como a "habilidade" analítica e explicativa do narrador balzaquiano, acerca do presente histórico, é construída na narrativa. O capítulo "As engrenagens do triunfo", de Illusions Perdues, é um bom exemplo da articulação entre o olhar histórico do narrador, que tem o poder de nos explicar seu tempo, e a intriga romanesca. A começar pelo próprio título e, também, pelo desenvolvimento de todo o capítulo, é possível verificar o entrecruzamento entre História e ficção que está articulado nos romances de modo geral.

Dans les pays devorés par les sentiments d'insubordination sociale caché sous le mot d'égalité, tout triomphe est un des ces miracles qui ne vas pas, comme certains miracles d'ailleurs, sans la coopération d'adroits machinistes. Sur dix ovations obtenues par des hommes vivants et décernées au sein de la patrie, il y en a neuf dont les causes sont étrangères au glorieux couronée. (...) Aussi les deux femmes avaient-elles raisons dans leurs pressentiments. Le succès du grand homme de province était trop antipathique aux mœurs immobiles d'Angoulême pour ne pas avoir été mis en scène par des intérêts ou par un machiniste passioné, collaborations également perfides. Ėve, comme la plupart des femmes d'ailleurs, se défiat par sentiment et sans pouvoir se justifier à elle-même sa défiance. Elle se dit en s'endormant: "Qui donc aime assez ici mon frère pour avoir excité mon pays ?... Les Marguerites ne sont d'ailleurs encore publiées, comment peut-on le féliciter d'un succès à venir ?... » 
Ce triomphe était en effect l'œuvre de Petit-Claud. Le jour où le curé de Marsac lui annonça le retour de Lucien, l'avoué dînait pour la première fois chez madame de Sénonches, qui devait recevoir officiellement la demande de la maison de sa pupille. Ce fut un des dîners de famille dont la solennité se trahit plus par la toilette que par le nombre des convives. ${ }^{147}$

O título do capítulo "As engrenagens do triunfo" diz respeito às operações que ocorrem, sem que saibamos, e que são responsáveis pelo "triunfo" de algo ou alguém. O triunfo não é um acontecimento em si, como um milagre, ao contrário, existem muitas razões que o constituem. O olhar do historiador é, então, capaz de ponderar as causas e avaliar o que de fato consagrou uma ideia ou uma pessoa. "As engrenagens" são as causas, normalmente não muito nobres nos romances balzaquianos que engendram a glória social. No romance, o triunfo é na verdade o "falso triunfo" de Lucien e as "engrenagens", os interesses das personagens - tipos sociais que retratam a vida provinciana e mesquinha de Angoulême - que desejam a derrota do jovem poeta.

O narrador inicia o capítulo explicando um dado da realidade histórica, "de dez ovações obtidas pelos homens vivos e obtidas no seio da pátria, há nove cujas causas são desconhecidas aos gloriosos coroados", para logo em seguida concluir que as duas personagens do romance tinham razão em temer pela glória de Lucien: "assim as duas mulheres tinham razão em seus pressentimentos". Quando o narrador diz "assim", ele transita do dado histórico para a intriga romanesca. É ele que irá esclarecer objetivamente os pressentimentos de Ève, ao revelar, em todos os seus detalhes materiais, a organização da sociedade de Angoulême e suas maquinações, por meio da descrição do "jantar de família". Para a intriga, uma cena importante, que irá nortear o futuro de Lucien, para o leitor, uma representação histórica dos valores sociais provincianos, onde os interesses comerciais da burguesia local mesclavam-se aos da aristocracia decadente - "Cointet (...) ofereceu aos olhares um diamante de seis mil francos em seu peitilho, a vingança do rico comerciante sobre a aristocracia pobre."148

\footnotetext{
${ }^{147}$ Balzac. Illusions Perdues. Op. Cit. p. 721-722. Itálico do autor.

148 "Cointet, vêtu de son plus bel habit marron à coupe ecclésiastique, offrit aux regards un diamant de six mille francs sur son jabot, la vengeance du riche commerçant sur l'aristocracie pauvre." IN: Balzac. Illusions Perdues, Op. Cit, p. 722.
} 
Revelar e explicar, narrar e descrever ${ }^{149}$ constituem a base do mosaico balzaquiano, sem que haja uma fronteira entre esses elementos. Difícil determinar se as ações e descrições revelam ou explicam. Para o olhar de historiador do narrador balzaquiano, a História é feita de ações e de descrições entrelaçadas em uma longa narrativa sobre o presente histórico que pretende, ao mesmo tempo, seduzir e informar seu leitor, cumprindo, desse modo, com a função do projeto literário que entrecruza história e ficção: o deleite e o conhecimento histórico. A comunhão entre a sedução e a informação na narrativa balzaquiana é muito forte e é claramente expressa em uns de seus prefácios quando o autor se compara a Xerazade e seus leitores (o público) ao sultão:

Ainsi donc cette longue histoire, où le public est le sultan, et l'auteur ressemble Schéhérazade, redoutant chaque soir, non pas de voir trancher sa tête, mais ce qui est pis, de se voir remercié comme radoteur (...). ${ }^{150}$

A importância do referencial histórico da realidade - ou seja, do compartilhamento do conhecimento da história do presente - além do elemento apaixonante que a narrativa pode oferecer é evidenciada no temor do autor em ser

149 Lukács aborda esse tema em seu conhecido ensaio "Narrar ou Descrever?". Em suas
considerações, nota-se uma contraposição entre o ato de narrar e descrever. Para o pensador, em
alguns romances há um predomínio da narração ou da descrição. Sendo assim, seu foco é examinar
qual seria a razão da preferência por um desses princípios de composição. Entre os exemplos, em
que ocorre o predomínio do ato de narrar, Lukács cita os romances de Balzac os quais se opõem aos
romances predominantemente descritivos de Zola. Não que a narrativa balzaquiana abandone as
descrições, porém elas estão entrelaçadas à narrativa. Em Zola, ao contrário, as descrições
simbolizam o fato social e não têm uma relação direta com a narrativa. São nas palavras do filósofo,
um caput mortuum da situação. Essa oposição diz respeito às questões ideológicas, ou da "posição
de princípio assumida pelo escritor, em face da vida, em face dos grandes problemas da sociedade,
e não do mero emprego de um diverso método de representar determinado conteúdo ou parte do
conteúdo." IN: Lukács, Georg. "Narrar ou Descrever?" Ensaios sobre Literatura. Coordenação e
prefácio de Leandro Konder. Rio de Janeiro: Civilização Brasileira, 1965, p.50.
Em seu ensaio, Lukács deixa transparecer um viés marxista ao perceber uma atitude passiva na
literatura que privilegia a descrição, perpetuando, dessa forma, o status quo, porque esse tipo de
narrativa não consegue encontrar a conexão entre a práxis e a vida interior do homem. A nosso ver,
Lukács está correto quando afirma que as descrições balzaquianas têm um papel importante para o
desenvolvimento da narrativa, porém nosso foco é diferente. Entendemos que não há uma hierarquia
entre esses dois princípios de composição, e que as descrições, no caso de Scott e Balzac, são
pensadas como um fundamento de representação histórica. Além disso, como discutimos acima, na
narrativa balzaquiana, as fronteiras entre narrar e descrever se desfazem, porque as descrições
também revelam, dizem "coisas". Como disse Antonio Candido, em alguns momentos, "narrar é
descrever". IN: Antonio Candido. O Discurso e a Cidade. São Paulo: Duas Cidades: Ouro Azul, 2004,
p. 61.

${ }^{150}$ Balzac. Une Fille d’Ève. Préface de la Première Édition. Op. Cit. p.187. 
considerado um "radoteur", ou seja, uma pessoa "caduca", fato que considera mais terrível do que ter a cabeça decepada.

No Avant-propos, Balzac reafirma a relevância da História para sua narrativa, ao explicar a gênese da Comédia Humana. Logo no início do texto, ele considera ser importante "falar do pensamento, contar a origem, e explicar brevemente o plano"151, da Comédia Humana. Resumidamente, o autor indica o caminho que percorrera na composição da sua grande obra. Notamos a passagem da intuição "a ideia inicial da Comédia Humana foi para mim como um sonho ${ }^{152 "-~ a ~ u m a ~}$ comparação entre a humanidade e o mundo animal ${ }^{153}$ - "Essa ideia veio de uma comparação entre a Humanidade e a Animalidade"154- para em seguida concluir que a diferença entre eles é o processo histórico, que imprime à espécie humana uma complexidade inexistente no mundo animal, sendo este último sempre o mesmo na passagem do tempo:

Quoique Leuwenhoëk, Swarmmerdam, Spallanzani, Réaumur, Charles Bonnet, Muller, Haller, et autres patients zoographes aient démontré combien les mœurs des animaux étaient intéressantes, les habitudes de chaque animal sont, à nos yeux du moins, constamment semblables en tout temps; tandis que les habitudes, les vêtements, les paroles, les demeures d'un prince, d'un banquier, d'un artiste, d'un bourgeois, d'un prêtre et d'un pauvre sont entièrement dissemblables et changent au gré des civilizations. ${ }^{155}$

Descoberta a importância da História para o entendimento da vida humana, Balzac define, finalmente, o objetivo de seu projeto literário:

\footnotetext{
151 "Il est nécessaire d'en dire la pensée, d'en raconteur l'origine, d'en expliquer brièvement le plan." IN: Balzac. "Avant-Propos" de la Comédie Humaine. Écrits Sur Le Roman. Op.Cit. p.277.

152 "L'idée première de la Comédie humaine fut d'abord pour moi comme un rêve". IN: Idem, Ibidem p.278.
${ }^{153}$ Vale ressaltar a historicidade subjacente a essa afirmação, uma vez que as discussões científicas faziam parte da ordem do dia no século XIX. Ao longo do Avant-propos Balzac cita vários nomes de cientistas que discutiam seus pontos de vista nas arcadas da academia sobre a organização do mundo animal. Essas discussões geravam disputas públicas entre os cientistas de ponto de vistas diferentes.

154 "Cette idée vint d'une comparaison entre l'Humanité et L'Animalité". IN: Balzac. "Avant-Propos" de la Comédie Humaine. Op. Cit. P.278.

${ }^{155}$ Balzac. "Avant-Propos" de la Comédie Humaine. Op. Cit. p.282-283.
} 
Mais comment rendre intéressant le drame à trois ou quattre milles personnages que présente une Société? comment plaire à la fois au poète, au philosophe et aux masses qui veulent la poésie et la philosophie sous des saisissantes images ? ${ }^{156}$

$\mathrm{Na}$ verdade, quando o autor atribui às massas o desejo de poesia e filosofia o termo filosofia aqui deve ser compreendido como a possibilidade do conhecimento histórico- e pergunta como agradar ao poeta e ao filósofo, ele está, em realidade, afirmando que o grande desejo da Comédia Humana é justamente fundir História e ficção, projeto literário que havia sido viabilizado por Walter Scott.

Si je concevais l'importance de la poésie de cette histoire du cœur humain, je ne voyais aucun moyen d'éxecution; car, jusqu'à notre époque, le plus célèbres conteurs avaient dépensé leur talent à créer un ou deux personnages typiques, à peindre une face de la vie. Ce fut avec cette pensée que je lus les œuvres de Walter Scott.

Foi esse "pensamento" crítico apurado sobre os romances de Walter Scott, desenvolvido paralelamente à composição de seus romances, que possibilitou a Balzac o entendimento da essência do modelo narrativo scottiano. Mesmo que para falar de sua época tenha sido necessário reconfigurá-lo, foi o olhar de historiador presente na narrativa scottiana que the permitiu revelar e explicar as contradições históricas da Restauração no seu romance realista ou na sua história do presente.

\footnotetext{
${ }^{156}$ Balzac. "Avant-Propos" de la Comédie Humaine. Op. Cit. p.284.

${ }^{157}$ Idem, Ibidem, p.284-285.
} 


\section{CONSIDERAÇÕES FINAIS}

Como vimos, o nome de Walter Scott se multiplica na escrita balzaquiana, tanto nos textos críticos quanto na prosa de ficção. Nesta última, como nos lembra R. K. Gordon, "muitas de suas personagens são, como seu criador, leitoras de Scott." "158 Esses "leitores" de Scott ora são ingênuos e admiram as peripécias do enredo, ora são críticos e analisam com lucidez a obra scottiana, assim como o próprio Balzac o faz. Walter Scott, nome tantas vezes repetido e reverenciado por Balzac, tornou-se um leitmotif em seus textos críticos e um referencial histórico na prosa de ficção - haja vista que os romances do autor escocês eram, de fato, sucesso entre o público leitor da Restauração.

Entretanto, a aproximação entre Walter Scott e Balzac foi pouco explorada pela crítica. Talvez, uma das razões dessa lacuna estaria relacionada a uma aparente obviedade. Afinal Walter Scott não havia sido uma mania na França oitocentista, disseminada nas artes em geral e até na vida cultural da sociedade francesa? ${ }^{159}$ A repetição do nome de Scott não seria auto-explicativa, comprovando, materialmente até, a presença de Walter Scott na obra balzaquiana? O que mais se pode dizer sobre a importância de Walter Scott que o próprio Balzac não tenha dito? Nosso estudo, como intencionamos demonstrar até aqui, não se rendeu à possível obviedade da aproximação entre os escritores.

Sobre esse julgamento crítico que poderia resultar apenas reduntante, Stéphane Vachon diz:

${ }^{158}$ Gordon, R. K. Scott and The "Comédie Humaine". IN: Sir Walter Scott To-day. Some Retrospective Essays and Studies. Edited for the Edinburgh Centenary Committee by H.J. Grierson. London: Constable \& Co, 1932. p.93-108.

159 "Mais do que um sucesso, na avaliação de Louis Maigron, Scott foi uma mania. Segundo ele, desde as modistas até as duquesas, desde as pessoas simples até os intelectuais, todos se renderam ao fascínio do escocês, cuja popularidade começou a se desenhar por volta de 1817 para atingir o auge no decênio de 1820. Paris viveu uma espécie de voga scottiana e essa paixão se corporificou em peças nos palcos parisienses, em quadros de Eugène Delacroix, Paul Delaroche e Ary Scheffer, no mobiliário e em vestimentas (como, por exemplo, gravatas e barretes), tudo inspirado em cenas dos romances." IN: Vasconcelos, Sandra Guardini Teixeira. "Figurações do passado: o romance histórico em Walter Scott e José de Alencar". Op.Cit. p.16. 
Les travaux de plusieurs éminents critiques nous ont, de longue date, prévenus contre la tentation d'établir une continuité absolue dans les jugements de Balzac sur "l'immortel Walter Scott". La présence et la prégnance dans la réflexion balzacienne du roman historique dont Walter Scott, le "premier romancier du siècle", serait le "créateur", ne ressemblent ni à l'inventaire d'une tradition qu'il faut solder, ni à un aprentissage dont il suffirait de se détourner. Elle sont tout sauf une forme de retard esthétique au moment où la gloire en France de l'auteur d'Ivanhoé commencerait à pâlir. L'étude de Walter Scott et du roman historique, la necessité d'être vrai, permettent à Balzac de se dégager du débat entre les classiques et les romantiques en dépassant les prémières théorisations fournies par la préface de Victor Hugo à Cromwell' ${ }^{100}$ en 1827 , et, l'année suivante, par celle d'Émile Deschamps aux Études françaises et étrangères. ${ }^{161}$

Nesse sentido, esse estudo não se desviou da questão e pode, assim, estabelecer um ponto de contato entre os escritores, fundamentado em uma reflexão sobre um elemento muito particular na formação de seus romances, que seria o desejo da representação histórica na prosa de ficção. Como afirma Vachon e já o havia mencionado Lukács, o interesse analítico da aproximação entre os escritores reside no estudo realizado por Balzac sobre Walter Scott, o que justifica a constante presença do autor escocês em sua obra, pois os romances de Scott eram seu objeto de estudo.

Da leitura dos prefácios de Balzac entendemos que Walter Scott não é uma obviedade, mas um conteúdo manifesto. ${ }^{162}$ Diante desse "documento", ou seja, a produção artística do autor escocês, Balzac produziu questionamentos, pôde

\footnotetext{
${ }^{160}$ Para Victor Hugo, o maior problema dos romances de Walter Scott era o seu aspecto prosaico, o qual, segundo ele, deveria ser ultrapassado para que se pudesse atingir a forma do romance que incorporasse 0 ideal e o poético. Mesmo reconhecendo a inventividade formal e a novidade dos detalhes da realidade histórica na prosa ficcional, somente o ideal e o poético o tornariam um romance perfeitamente acabado. Dessa forma o projeto Romântico de Victor Hugo acaba afastandose do prosaico e do próprio Walter Scott.
}

${ }^{161}$ Vachon, Stéphane. "Balzac théoricien du roman". IN: Balzac. Op. Cit. p.27: "Os estudos de vários críticos eminentes têm nos prevenido, há muito tempo, contra a tentação de estabelecer uma continuidade absoluta nos julgamentos de Balzac sobre o "imortal Walter Scott". A presença e a abundância na reflexão balzaquiana sobre o romance histórico, do qual Walter Scott, o "primeiro romancista do século", seria o "criador", não se parecem nem ao inventário de uma tradição que se deve resolver, nem a um aprendizado do qual bastaria se desviar. Elas são tudo menos uma forma de atraso estético no momento em que a glória na França do autor de Ivanhoé começaria a enfraquecer. O estudo de Walter Scott e do romance histórico, a necessidade de ser verdadeiro, possibilitam a Balzac se distinguir do debate entre os clássicos e os românticos superando as primeiras teorizações fornecidas pelo prefácio de Victor Hugo a Cromwell em 1827, e, no ano seguinte, por aquele de Émile Deschamps ao Études françaises et étrangères."

${ }^{162}$ Quando discute o sentido hermenêutico do texto, Pomian afirma que nenhuma obra se reduz ao seu conteúdo manifesto. Esse é necessariamente acompanhado de um conteúdo latente, veiculando tudo que o autor de uma obra, ao produzi-la, deixou que entrasse sem ser consciente e que consequentemente não é dado como óbvio. A abertura ao conteúdo latente somente ocorre pela interpretação do conteúdo manifesto. IN: Pomian, Krzysztof. Op. Cit. p.12. 
compreender as possibilidades e os procedimentos de representação histórica na prosa ficcional, enfim, foi-lhe possível incorporar na sua Comédia Humana um olhar historiográfico para realizar a sua história do presente. A ideia a respeito da confluência entre uma discussão sobre a escrita da História e a composição do romance balzaquiano é reiterada por Paule Petitier, quando afirma que "se compararmos a evolução da disciplina histórica no início do século XIX e o desenvolvimento da carreira de Balzac, ficaríamos impressionado com um ponto de concordância." Petitier conclui ainda que o romance balzaquiano apresenta uma característica distinta em relação à escrita historiográfica que lhe era contemporânea:

Balzac n'ignore pas l'histoire des historiens et sa poétique romanesque s'élabore sur la conception identique d'une évolution complexe résultant d'une multiplicité de facteurs. Cependant son histoire du présent se construit sur le deuil de la grande histoire avec une penétration toute mélancolique à saisir la petitesse des motifs et des acteurs qui produisent continûment les grands chagements. ${ }^{163}$

Incluímos, nesse apontamento da crítica, o fato de que foi o programa scottiano que possibilitou a Balzac vislumbrar o "outro lado da história contemporânea", isto é, a história do detalhe, do homem comum. E como quisemos mostrar, foi o estudo realizado por Balzac dos romances de Walter Scott que lhe indicou não só o parentesco entre a História e o romance, mas também um olhar que possibilita à prosa ficcional, mesmo que esta tenha como objeto a realidade histórica, uma reordenação distinta da narrativa histórica.

Dentre os raros estudos dedicados a essa aproximação, alguns têm como embasamento uma leitura sobre gênero narrativo, concentrando-se na comparação entre Les Chouans e Waverley ${ }^{164}$, romances com temáticas parecidas e que

\footnotetext{
${ }^{163}$ Petitier, Paule. "Balzac et la 'Clio Classique'”. IN: Mozet, Nicole et Petitier, Paule (éds.). Op. Cit. p. 15. "Balzac não ignora a história dos historiadores e sua poética romanesca se elabora a partir de uma concepção idêntica de uma evolução complexa resultante de uma multiplicidade de fatores. Entretanto, sua história do presente se constrói sobre o luto da grande história, com uma penetração melancólica, para apreender a pequenez dos motivos e dos atores que produzem continuamente as grandes mudanças."

${ }^{164}$ Citamos aqui o artigo de Haggis, D. R. Scott, Balzac, and the Historical Novel as Social and Political Analysis: "Waverley" and "Les Chouans". IN: The Modern Language Review, Vol. 68, No. 1, (Jan., 1973), pp. 51-68 Published by: Modern Humanities Research Association Stable URL: http://www.jstor.org/stable/3726203.
} 
apresentam uma clara filiação textual. Outros apresentam uma abordagem intertextual $^{165}$, pontuando trechos dos romances em que Balzac claramente se apropria de construções narrativas scottianas. De todas as análises, destacamos a de H. J. Garnand, The Influence of Sir Walter Scott de 1926, uma vez que se trata de uma das poucas obras publicadas - senão a única - referente a um estudo comparativo entre os romances de Walter Scott e Balzac. De modo geral, as publicações se atêm à análise comparativa de apenas um romance de cada autor.

O argumento principal de Garnand ${ }^{166}$ gira em torno da ideia do romance scottiano como um modelo narrativo para Balzac. O crítico se concentra nos aspectos formais da obra, preocupando-se especialmente com a semelhança entre determinadas personagens, enredo e descrições, desenvolvida apenas no nível textual para demonstrar como as similaridades, ou como a "influência" de Scott na prosa ficcional de Balzac, são mais acentuadas em seus romances de juventude e perdem força à medida que o autor francês desenvolve seu grande projeto literário que foi a Comédia Humana. O último capítulo é dedicado às conclusões e intitula-se "Scott versus Balzac". Nesse capítulo, o crítico escolhe passagens de dois romances - La Maison du Chat qui Pelote e The Fortunes of Nigel - e a partir daí apresenta algumas proposições que sustentam sua tese sobre a independência do "sistema" balzaquiano, em relação ao scottiano, no desenvolvimento de seus romances. Dentre as proposições, apontamos três que consideramos interessantes para nossas considerações finais.

A primeira proposição diz respeito ao desenvolvimento de cada romance em relação à mesma temática, a segunda às diferenças dos desfechos dos romances dos dois autores e a terceira ao sentido de unidade dos romances de Balzac.

\footnotetext{
${ }^{165}$ A esse respeito ver: Déruelle, A. Le "singe de Walter Scott»? "L'Excommunié» et "Quentin Durward». IN: L'Année balzacienne 2006/1, N7, p. 361-377; e Tilby M. Sur quelques él éments intertextuels des Paysans; Balzac, Walter Scott et Théophile Gautier. IN: L'Année balzacienne 2001/1, n², p. 283-304.

${ }^{166}$ Cabe ressaltar que o estudo comparativo de Garnand é de 1926 e, portanto, apresenta conceitos um tanto quanto datados como o de "influência", entendido mais como imitação na medida em que prioriza os detalhes materiais da obra, como explica Sandra Nitrini: "Até certo ponto, a influência pode confundir-se com imitação (...). Nesse caso, o matiz que diferencia as duas noções é que a imitação refere-se a detalhes materiais como traços de composição, a episódios, procedimentos, ou tropos bem determinados (....." IN: Nitrini, Sandra. Literatura Comparada. História, Teoria e Crítica. São Paulo: Edusp, 2000, p.127.
} 
Se examinarmos, resumidamente, cada uma das proposições, veremos que, para cada uma, há também um nível extratextual atuando na prosa de ficção, o qual, de certa maneira, está reordenado no mundo imaginário. Garnand não procura no seu estudo indicar "a fórmula segundo a qual a realidade do mundo ou do espírito foi reordenada, transformada, desfigurada ou até posta de lado, para dar nascimento a outro mundo."167 Para ele, basta a organização estético-formal do texto, o que o leva a colocar a narrativa scottiana em oposição à balzaquiana, construindo uma espécie de comparação especular entre os romances à procura apenas de simetrias e assimetrias no nível do texto.

Por exemplo, sobre a temática, Garnand afirma que os dois romances, citados acima, apresentam uma mesmo questão, resumida assim: "A união entre duas pessoas de diferente posição social pode ser realizada e com quais resultados?". ${ }^{168}$ Segundo o crítico, a resposta à questão, encontrada nesses romances, é completamente diferente, devido à maneira como cada autor desenvolve a intriga do romance. No que tange aos desfechos, enquanto o dénouement feliz é "praticamente universal em Scott", ${ }^{169}$ o mesmo não ocorre nos romances balzaquianos; o motivo da assimetria residiria em visões de mundo distintas. Finalmente, em relação à unidade presente na Comédia Humana e ausente no sistema scottiano, - porque cada romance dos Waverley Novels constitui "uma Comédia Humana em miniatura"170 - a questão é uma diferença de "estilo". Como podemos notar, em nenhum momento a ideia de representação histórica é tratada no jogo de espelhos armado por Garnand.

Nosso estudo procurou demonstrar como o olhar historiográfico da narrativa romanesca scottiana e balzaquiana tem um papel ativo nessas simetrias e assimetrias entre os escritores. Sob esse aspecto, em vista de um contexto histórico

\footnotetext{
${ }^{167}$ Antonio Candido. "De Cortiço a Cortiço." O Discurso e a Cidade. São Paulo: Duas Cidades: Ouro Azul, 2004, p.105.

168 "Can a union between two people of different degrees of birth be brought about and with what results?" IN: Garnand, H.J. "Balzac versus Scott". The Influence of Walter Scott on the Works of Balzac. New York: Octagon Books, 1971, p.140.

169 "(...) is practically universal with Scott, the ending is happy." IN: Idem, Ibidem, p.146.

170 "With Scott (...) each novel is a miniature Comédie Humaine." IN: Idem, Ibidem, p.146.
} 
específico a cada escritor, as questões sócio-históricas subjacentes à união matrimonial era um "material" histórico completamente diferente na Escócia medieval e na sociedade da Restauração, daí as diferenças encontradas naqueles romances. Em relação à explicação da unidade do sistema balzaquiano, é a problemática do tempo histórico e não apenas uma manobra estilística que se sobressai no arranjo formal dos romances. Já para os desfechos dos romances scottianos, era a busca de uma identidade nacional que os "forjava" felizes, pela necessidade ideológica de configurar uma conciliação entre as forças contrárias em luta. A reconstrução do passado nos romances dos Waverley Novels era assumidamente preocupada com o "resgate" positivo das tradições do povo escocês. Em The Heart of Midlothian, por exemplo, ao contrário do seu êmulo histórico, Helen Walker, Jeanie Deans é agraciada com uma vida feliz, ao contrário de sua irmã Effie. A reviravolta é significativa. Effie simboliza, no romance, o progresso civilizatório, pois ela abandona o espaço sócio-cultural das Terras Altas e passa a viver sob os códigos da sociedade inglesa - em um dado momento do final do romance, Jeanie não reconhece a própria irmã que agora se comportava como uma "lady". Jeanie também se modifica em contato com o mundo progressista, porém ela não abandona seus códigos e tradições. Nesse sentido, diante do processo civilizatório necessário, é o abandono total das tradições que embrutece a experiência histórica. No mundo da Comédia Humana, não se trata de desenlaces infelizes, mas da representação de uma dimensão histórica do presente que não se abre para a possibilidade de um futuro.

A partir da leitura dos textos críticos de Walter Scott e Balzac, pudemos averiguar uma aproximação entre os escritores que vai além de paisagens descritivas que se assemelham, ou temáticas que se repetem. A visão crítica desenvolvida pelos romancistas nos ajudou a rastrear o que estava em jogo conceitualmente, no momento da formação de seus romances, pois ao compararmos os textos críticos à prosa ficcional percebemos nitidamente como se operou a associação "da ideia de montagem, que denota artifício, à de processo, que evoca a marcha natural". ${ }^{171}$ Segundo Antonio Candido, é essa associação que possibilita o entendimento da "natureza ambígua, não somente do texto (que é e

\footnotetext{
${ }^{171}$ Antonio Candido. Op. Cit. p. 106.
} 
não é fruto de um contato com o mundo), mas de seu artífice (que é e não é um criador de mundos novos)." 172

Sujeitos históricos que vivenciaram as reviravoltas revolucionárias e foram contemporâneos de um debate que se intensificava sobre a escrita da História, Walter Scott e Balzac não ficaram refratários à nova visão de mundo e a incorporaram como um eixo importante na composição de seus romances para a explicação da vida real.

O movimento dialético entre a "montagem" e o "processo", isto é, entre o real e o imaginário, apontado por Antonio Candido, está sempre presente nos apontamentos de Walter Scott e Balzac. Para Scott, "Indeed, the most romantic parts of this narrative are precisely those which have a foundation in fact"173, enquanto Balzac afirma que "J'ai mieux fait que l'historien, je suis plus libre."174 Proposições quase paradoxais, se não considerarmos a questão dialética mencionada acima. No exemplo de Scott, a palavra "romântica", além de seu significado habitual, denota a qualidade do imaginário da narrativa romanesca e, de maneira inesperada, é vinculada ao "fato", ao real. Ora, não seria o contrário, não seria o mundo fictício mais romântico, isto é, mais ideal, do que a vida prosaica? Como fica expresso, o "belo ideal" da literatura para Walter Scott é a possibilidade de se representar a história da vida humana.

No caso de Balzac, quando argumenta ter feito melhor do que um historiador, sendo mais livre, seu pensamento parece opor-se a sua máxima "Il est historien, voilà tout!". No entanto, sabemos que o programa balzaquiano intenciona produzir o conhecimento histórico na narrativa romanesca. A prosa ficcional é livre e não está submetida às mesmas exigências de correção da narrativa histórica. Dessa forma, ao se dizer livre, Balzac parece prever a leitura equivocada de sua narrativa por quem a entende apenas como uma "duplicação da realidade"175. Sobre essa leitura,

\footnotetext{
${ }^{172}$ Antonio Candido. Op. Cit. p.106.

173 Scott, Walter. "Waverley (1814). A Postscript Which Should Have Been a Preface". Op.Cit. p. 4.

${ }^{174}$ Balzac, "Avant-Propos" de la Comédie Humaine. Op. Cit. p.297.

${ }^{175}$ Antonio Candido, Op. Cit. p. 106.
} 
a liberdade defendida por Balzac no romance condiz com o questionamento de Antonio Candido: "se era para fazer igual, porque não deixar a realidade em paz?". ${ }^{176}$

Impulsionados por um fascínio pelo romance ${ }^{177}$ e um veio analítico marcante, Walter Scott e Balzac constituíram, em seus textos críticos, um importante protocolo para a história do romance oitocentista. $\mathrm{Na}$ instância não-ficcional de sua obra, documentaram nitidamente como operou a fronteira sutil entre o mundo próprio do romance e o mundo real. Para eles, foi a História que os direcionou à realidade, o que nos leva a concluir sobre a importância de se refletir sobre o papel da historiografia na formação dos romances do dois autores, sobretudos nos de Balzac, que convencionamos denominar "realistas".

\footnotetext{
${ }^{176}$ Antonio Candido, Op. Cit. p.106.

${ }^{177}$ Em uma carta a Mme Hanska, que foi não somente o grande amor, mas uma espécie de afinidade eletiva de Balzac, o autor francês externa sua paixão pelo romance após lhe explicar seu projeto literário: " Croyez-vous, madame, que j'aie beaucoup de temps à perdre aux pieds d'une parisienne. Non; il fallait choisir. Hé bien, je vous ai aujoud'hui découvert ma seule maîtresse; je lui ai ôté ses voiles, voilà l'œuvre, voilà le gouffre, voilà la cratère, voilà la matière, voilà la femme, voilà ce qui prend mes nuits, mes jours(...)" IN: Balzac. "Lettre à madame Hanska, 26 octobre 1834." Écrits Sur Le Roman. Textes choisis, présentés et annotés par Stéphane Vachon. Paris: Le Livre De Poche, 2000, p. 84.
} 


\section{BIBLIOGRAFIA}

\section{DOS AUTORES}

BALZAC, Honoré de. Illusions Perdues. Paris: Le Livre De Poche, 2006.

. Écrits Sur Le Roman. Textes choisis, présentés et annotés par Stéphane Vachon. Paris : Le Livre De Poche, 2000.

. Eugénie Grandet. Paris: Classique Français, 1993.

. Histoire des Treize. Paris: Pocket, 1992.

. La Peau du Chagrin. Paris: Garnier-Flammarion, 1971.

L'Envers de L'Histoire Contemporaine. Paris: Gallimard, 1970.

. Le Père Goriot. Paris: Gallimard, 1971.

. Les Chouans. Paris: Le Livre De Poche, 1997.

Une Fille d'Ève. Paris: Flammarion, 1965.

SCOTT, Sir Walter. Waverley. London: Penguin Popular Classics, 1994.

The Bride of Lammermoor. Oxford [England]; New York:

Oxford University Press, 1991. 
. The Heart of Midlothian. London: Thomas Nelson and Sons,

1906.

Old Mortality. London: Oxford University Press, 1999.

- The Prefaces to the Waverley Novels by Sir Walter Scott

edited by Mark A. Weinstein. Lincoln and London: University of Nebraska Press, 1978.

GERAL

ABENDROTH, Wolfgang et al. Entretiens avec Georg Lukács. Paris: Librarie François Maspero, 1969.

ADORNO, Theodor W. "Lecture de Balzac". Notes sur la Littérature. Traduit de l'allemand par Sibylle Muller. Paris: Flammarion, 1984, p.83-100.

ANTUNES, Ricardo e Leão Rêgo, Walquíria (org.). Lukács: um Galileu no Século XX. São Paulo: Boitempo, 1996.

AUERBACH, Erich. Mimesis. São Paulo: Perspectiva, 2004.

ANTONIO CANDIDO. Formação da Literatura Brasileira. 6.ed. Belo Horizonte: Editora Itatiaia Limitada, 1981.

. O Discurso e a Cidade. São Paulo : Duas Cidades: Ouro Azul, 2004.

. Literatura e Sociedade. Rio de Janeiro: Ouro sobre Azul, 2006. 
BANN, Stephen. "Clio in part: on antiquarianism and the historical fragment". IN: The Inventions of History: Essays on the Representation of the Past. Manchester and New York: Manchester University Press, 1990, p.100-122.

BERRY, Christopher J. "Science, Explanation and History" IN: Social Theory of the Scottish Enlightenment. Edinburgh: Edinburgh University Press, 1997, p.52-74.

BORDINI, Maria da Glória (org.) et al. Lukács e a Literatura. Porto Alegre: EDIPUCRS, 2003.

CURLY, Maria Odila Dias. Brasil Na Historiografia Romântica Inglesa. 1965. 1v. 287p. Dissertação de Mestrado - Faculdade de Filosofia, Letras e Ciências Humanas, Universidade de São Paulo, São Paulo.

CURTIUS, Ernest R. Balzac. Paris: Éditions Bernard Grasset, 1933.

DELATTRE, Geneviève. Les Opinions Littéraires de Balzac. Paris: Presse Universitaires de France, 1961.

DERUELLE A. Le « singe de Walter Scott »?. «L'Excommunié» et «Quentin Durward», L'Année balzacienne 2006/1,№ 7, p. 361-377.

DUCHEIN, Michel. Histoire de L'Écosse. Paris: Fayard, 1998.

GARNAND, H.J. The Influence of Walter Scott on the Works of Balzac. New York: Octagon Books, 1971.

GARSIDE, Peter D. Scott and The "Philosophical" Historians. Journal of the History of Ideas, no. 3, 1975, p. 497-512.

GASTON, Patricia S. Prefacing the Waverley Prefaces. New York: Peter Lang Publishing, 1991.

GENETTE, Gérard. Seuils. Paris : Éditions du Seuil, 1987. 
GENGEMBRE, Gérard. Le Roman Historique. Paris : Klinscksieck, 2006.

GORDON, R.K. Scott And The "Comédie Humaine". IN: Sir Walter Scott To-day. Some Retrospective Essays and Studies. Edited for the Edinburgh Centenary Committee by H.J. Grierson. London: Constable \& Co, 1932, p.93-108.

HELLER, Agnes; FÉHÉR, Ferenc. "Historical Novel and History in Lukács". IN: The Grandeur and Twilight of Radical Universalism. New Jersey: Transaction Publishers, 1991, p.275-290.

HELLER, Agnes (org.). Lukács Reappraised. New York: Columbia University Press, 1993.

HIRSCHMAN, Albert. As Paixões e os Interesses. - Argumentos Políticos a Favor do Capitalismo antes de seu Triunfo. Tradução de Luiz Guilherme B. Chaves e Regina Bhering. Rio de Janeiro: Editora Record, 2002.

HOBSBAWM, Eric. A Era do Capital 1848-1875. São Paulo: Editora Paz e Terra, 1996.

A Era das Revoluções 1789-1848. Rio de Janeiro: Paz e Terra,

1982.

LEVIN, Harry. The Gates of Horn: A Study of Five French Realists. New York: Oxford University Press, 1963.

LUKÁCS, Georg. A Teoria do Romance. Tradução de José Marcos Mariani de Macedo. São Paulo: Editora 34, 2000.

- Balzac et le Réalisme Français. Avant-propos. Traduit de l'allemand par Paul Laveau. Paris: La Découverte/Poche, 1999. 
.Balzac: Les Illusions Perdues" e "A polêmica entre Balzac e Stendhal". IN: Ensaios sobre literatura. Rio de Janeiro: Civilização Brasileira, 1968, p.95-137.

. "Qu'est Que Le Marxisme Orthodoxe?" IN: Histoire et Conscience de Classe. Paris : Les Editions de Minuit, 1960, p.17-45.

- Le Roman Historique. Tradução de Robert Sailley. Paris: Petite Bibliothèque Payot, 2000.

. "Narrar ou Descrever ?". IN: Ensaios sobre Literatura. Coordenação e prefácio de Leandro Konder. Rio de Janeiro: Civilização Brasileira, 1965, p.43-94.

LYONS, Martin. Le Triomphe du Livre : une histoire sociologique de la lecture dans la France du XIXe siècle. Paris: Promodis, 1987.

MAXWELL, Richard. "Scott in France". IN: Pittock, Murray (ed.). The Reception of Sir Walter Scott in Europe. London: Continuum, 2006, p.13.

MOZET, Nicole et Petitier, Paule (éds.). Balzac dans L'Histoire.Paris: SEDES, Collection du Bicentenaire, 2001.

NITRINI, Sandra. Literatura Comparada. História, Teoria e Crítica. São Paulo: Edusp, 2000.

NOVAES, Adauto (org.). O desejo. São Paulo: Companhia das Letras, 1999, Os Sentidos das Paixões. São Paulo: Companhia das Letras, 2006.

PERRONE-MOISÉS, Leyla. Flores da escrivaninha. São Paulo: Companhia das Letras, 1990.

POMIAN, Krzysztof. "Histoire et Fiction". Paris: Gallimard. Le Débat, número 54, 1989, p.114-137. 
Préfaces des Romans Français du XIX Siècle. Anthologie établie, présentée et annotée par Jacques Noiray. Paris: Le Livre De Poche, 2007.

REIS, José Carlos. História \& Teoria. Historicismo, Modernidade, Temporalidade e Verdade. Rio de Janeiro: Editora FGV, 2006.

RICCEUR, Paul. "Vers une Herméneutique de la Conscience Historique." IN : Le Présent Historique. Temps et Récit. Paris: Éditions du Seuil, 1985, tome III, p. 300345.

RIGNEY, Ann. Imperfect Histories: The Elusive Past and the Legacy of Romantic Historicism. Ithaca: Cornell University Press, 2001.

RONAI, Paulo. Balzac e A Comédia Humana. São Paulo: Editora Globo, 1993.

STARLING, Elizabeth. "Sisterly Affection". IN: Noble Deeds of Woman; or, Examples of Female Courage and Virtue. Boston, MA: Phillips, Sampson \& Co., 1850, p.66-69.

SCHWARZ, Roberto. Duas Meninas. São Paulo: Companhia das Letras, 1997.

SHAW, Harry E. "An Approach to the Historical Novel". IN: The Forms of Historical Fiction: Sir Walter Scott and his Successors. Ithaca, N.Y.: Cornell University Press, 1983.

Narrating Reality. Austen, Scott, Eliot. Ithaca and London: Cornell University Press, 1999.

SILVA, Arlenice Almeida da. O Épico Moderno : O Romance Histórico de György Lukács. 1999. 220p. Tese de Doutorado - Faculdade de Filosofia, Letras e Ciências Humanas, Universidade de São Paulo, São Paulo. 
TILBY M., Sur quelques éléments intertextuels des Paysans; Balzac, Walter Scott et Théophile Gautier, L'Année balzacienne 2001/1, n², p. 283-304.

VACHON, Stéphane (org.) Honoré de Balzac: Mémoire de la critique. Paris: Presses de l'Université de Paris-Sorbonne, 1999.

VASCONCELOS, Sandra Guardini Teixeira. A Formação do Romance Inglês. São Paulo: Hucitec, Fapesp, 2007.

"Figurações do passado: o romance histórico em Walter Scott e José de Alencar". Terceira Margem. Rio de Janeiro, 2008, v.12, n.18, p.15-37.

Woolf, Daniel R. A Global Encyclopedia of Historical Writing: K-Z. New York: Garland Pub., 1998, 2v, p.819-820.

\section{TEXTOS INTERNET}

HAGGIS, D. R. Scott, Balzac, and the Historical Novel as Social and Political Analysis: "Waverley" and "Les Chouans". IN: The Modern Language Review, Vol. 68, No. 1, (Jan., 1973), pp. 51-68 Published by: Modern Humanities Research Association Stable URL: http://www.jstor.org/stable/3726203

PESAVENTO, Sandra Jatahy, " História \& literatura: uma velha-nova história ", Nuevo Mundo Mundos Nuevos [En línea], Debates, 2006, Puesto en línea el 28 janvier 2006. URL : http:// nuevomundo.revues.org/index1560.html

MCLEMAN-CARNIE, Janette. "Sir Walter Scott and The French Press: Paris 1826" IN: International Review of Scottish Studies. Ontario: University of Guelph, volume 25, 2000, p.26-43. URL: http://www.irss.uoguelph.ca. 